RAFAELA MARIA RIOS DOS ANJOS

\title{
MAPEAMENTO DOS DETERMINANTES ESTRUTURAIS DA PROTEÍNA Rtg2p, ENVOLVIDOS NA SINALIZAÇÃO RETRÓGRADA E NO ENVELHECIMENTO DE Saccharomyces cerevisiae
}

Dissertação apresentada ao Programa de PósGraduação em Interunidades em Biotecnologia USP/Instituto Butantan/IPT, para obtenção do Título de Mestre em Ciências.

São Paulo

2016 
RAFAELA MARIA RIOS DOS ANJOS

\title{
MAPEAMENTO DOS DETERMINANTES ESTRUTURAIS DA PROTEÍNA Rtg2p, ENVOLVIDOS NA SINALIZAÇÃO RETRÓGRADA E NO ENVELHECIMENTO DE Saccharomyces cerevisiae
}

\author{
Dissertação apresentada ao Programa de Pós- \\ Graduação em Interunidades em Biotecnologia \\ USP/Instituto Butantan/IPT, para obtenção do \\ Título de Mestre em Ciências. \\ Área de concentração: Biotecnologia \\ Orientador:
}

Prof. Dr. José Ribamar dos Santos Ferreira Júnior

Versão Original

São Paulo

2016 
DADOS DE CATALOGAÇÅO NA PUBLICAÇÅO (CIP)

Serviço de Biblioteca e Informação Biomédica do

Instituto de Cièncias Biomédicas da Universidade de São Paulo

O reproduçáo total

Anjos, Rafaela Maria Rios dos.

Mapeamento dos determinantes estruturais da proteina Rtg2p. envolvidos na sinalização retrógrada e no envelhecimento de

Saccharomyces cerevisiae / Rafaela Maria Rios dos Anjos. - Säo

Paulo, 2016.

Orientador. Prof. Dr. José Ribamar dos Santos Ferreira Júnior.

Dissertaçäo (Mestrado) - Universidade de Säo Paulo. Instituto de Ciências Biomédicas. Programa de Pós-Graduaçäo Interunidades em Biotecnologia USP/IPT/Instituto Butantan. Área de concentraçäo: Biotecnologia. Linha de pesquisa: Mecanismos biológicos do envelhecimento.

Versäo do título para o inglês: Structural mapping of Rtg2p determinants involved in retrograde signaling and aging of Saccharomyces cerevisiae.

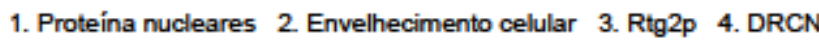
5. Saccharomyces cerevisiae 6 . Sinalizaçäo retrógada I. Ferreira Júnior, Prof. Dr. José Ribamar dos Santos III. Universidade de Säo Paulo. Instituto de Cièncias Biomédicas. Programa de Pós-Graduaçäo Interunidades em Biotecnologia USP/IPT/Instituto Butantan III. Titulo. 
UNIVERSIDADE DE SÃO PAULO

Programa de Pós-Graduação Interunidades em Biotecnologia Universidade de São Paulo, Instituto Butantan, Instituto de Pesquisas Tecnológicas

Candidato(a):

Rafaela Maria Rios dos Anjos.

Título da Dissertação: $\quad$ Mapeamento dos determinantes estruturais da proteína Rtg2p, envolvidos na sinalização retrógrada e no envelhecimento de Saccharomyces cerevisiae.

Orientador(a):

Prof. Dr. José Ribamar dos Santos Ferreira Júnior.

\section{A Comissão Julgadora dos trabalhos de Defesa da Dissertação de Mestrado, em sessão pública realizada a I. considerou \\ ( ) Aprovado(a) \\ ( ) Reprovado(a)}

Examinador(a): Assinatura:

Nome:

Instituição:

Examinador(a): Assinatura:

Nome:

Instituição:

Presidente: $\quad$ Assinatura:

Nome:

Instituição: 


\section{$\mathrm{EACH}$}

Escola de Artes Ciencias e Hurnanidades

da Universidade de Sao Paulo

São Paulo, 07 de julho de 2014.

Prof. Dr. José Ribamar dos Santos Ferreira Junior - Orientador

Rafaela Maria dos Anjos - Orientanda

Projeto de Mestrado - "Mapeamento dos determinantes estruturais da proteína Rtg2p, envolvidos na sinalização retrógrada e no envelhecimento de Saccharomyces cerevisiae" Instituição - Escola de Artes, Ciências e Humanidades - EACH/USP

De acordo com a Lei Federal № 11.794, de 8 de outubro de 2008, somente estão sujeitos à análise pelo CEUA os projetos de pesquisa ou atividade de ensino que envolvam animais do filo Chordata, subfilo Vertebrata.

Dessa forma, declaro que o referido estudo não se enquadra nessas normas e, portanto, está isento de análise ou aprovação por esse CEUA.

Atenciosamente,

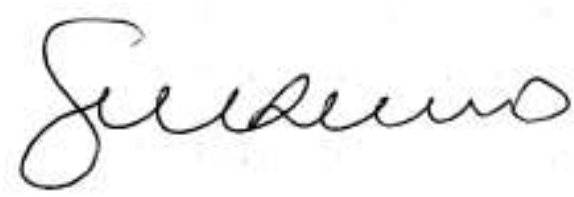

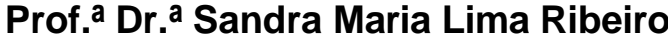

Comitê de Ética em Uso de Animais em Experimentação EACH/USP 
Dedico este trabalho a Deus e a meus pais Ione e Rodnei. 


\section{Agradecimentos}

Á Deus, pelo folego de vida e por toda a oportunidade que me foi dada.

Aos meus pais Ione e Rodnei, por todo apoio, incentivo e compreensão em todos os momentos, mesmo nos quais eu me tornei muito ausente para desenvolver esse trabalho. E principalmente por toda oração feita por vocês para que tudo desse certo!!!

Ao meu orientador José Ribamar dos Santos Ferreira Júnior, a quem tenho como um grande exemplo de cientista e ser humano, por não ser só um orientador, mas um incentivador, por sempre acreditar em mim!! Thank you for your guidance! I am eternally grateful for everything you've taught me!!

Aos meus amigos do Laboratório Ana, Dani, Fábio e Monica por todo apoio, incentivo, todos os artigos lidos, pelas risadas e por toda ajuda nesse trabalho, em especial à Vittoria uma amiga desde o primeiro dia que eu iniciei o mestrado, por toda contribuição no desenvolvimento deste trabalho. Obrigado!!

Aos colegas do laboratório vizinho, Patrícia, Gabriel e Flávia, por me receberem tão bem quando cheguei a EACH. Ao Professor Felipe Chambergo por disponibilizar o uso de alguns equipamentos fundamentais para o desenvolvimento do trabalho.

Ao professor Lucas Bleicher, por me receber muito bem em Minas Gerais, pelas análises de bioinformática e principalmente por disponibilizar um tempo para me ensinar um dos métodos mais fantásticos que correlaciona a evolução com a estrutura da proteína, o DRCN.

Ao professor Mario Henrique de Barros, por nos acolher no período de interdição da EACH, sem ele não seria possível o início desse trabalho e aos seus alunos (Bruno, Letícia, Raquel, Ana e Janaina) por nos receber tão bem nesse início.

A professora Fernanda Marques da Cunha, por me receber em seu laboratório e me ajudar nos ensaios que lá realizei.

Aos membros da banca de qualificação: Prof ${ }^{\mathrm{a}}$. Dra ${ }^{\mathrm{a}}$. Andrea Balan, Prof. Dr. Erich Birelli Tahara e Prof ${ }^{a}$. Dr ${ }^{a}$. Renata Pascon, por todas as valiosas sugestões que foram feitas para aperfeiçoar este trabalho.

Aos meus amigos da vida (Porque há vida fora do mestrado rsrs)!

À CAPES, pela bolsa concedida e à FAPESP pelo financiamento do projeto. 
"In a dark place we find ourselves and a little more knowledge lights our way" 


\section{RESUMO}

RIOS-ANJOS, R. M. Mapeamento dos determinantes estruturais da proteína Rtg2p, envolvidos na sinalização retrógrada e no envelhecimento de Saccharomyces cerevisiae. 2016. 97 p. Dissertação (Mestrado em Biotecnologia) - Instituto de Ciências Biomédicas, Universidade de São Paulo, São Paulo, 2016.

Em Saccharomyces cerevisiae, Rtg2p é uma proteína que participa da sinalização retrógrada, uma via de comunicação da mitocôndria para o núcleo. Ao se ligar ao fator negativo Mks1p, Rtg2p permite que o complexo Rtg1/3p desloque-se para o núcleo para ativar a transcrição de genes nucleares, em resposta à disfunção mitocondrial. Além do papel na resposta retrógrada, Rtg2p tem sido associada com a longevidade celular, pois células com o gene $R T G 2$ rompido (rtg2 2 ) apresentam longevidade reduzida. Rtg2p possui um domínio N-terminal importante para sua função que está relacionado com a sinalização retrograda e o envelhecimento em levedura, entretanto, nenhum mapeamento estrutural detalhado foi realizado neste domínio. $\mathrm{O}$ objetivo deste trabalho foi identificar os determinantes estruturais de Rtg2p, envolvidos na sinalização retrógrada e no envelhecimento. Para isto foram produzidos treze mutantes pontuais (L56G, E106A, E106H, R109E, N113A, E137A, D158A, T138A, A160G, G161A, $S 163 A, Q 165 A, Q 165 E)$ por mutagênese sítio-dirigida, a partir de desenho racional por decomposição de redes de correlação de aminoácidos (DRCN). Analisaram-se as cepas mutantes por ensaio de auxotrofia para glutamato, mediu-se a expressão do gene CIT2 e realizou-se ensaio de longevidade replicativa em todas as cepas. Em particular, destacaram-se as cepas $N 113 \mathrm{~V}$ e $Q 165 \mathrm{~A}$ que não apresentaram auxotrofia para glutamato e tiveram a expressão do gene $C I T 2$ superior à da cepa $\operatorname{rtg} 2 \Delta$; também destacou-se a cepa $E 137 A$, que apresentou um crescimento inferior às demais, mesmo com a adição do glutamato; isso pode indicar que essa mutação afeta uma atividade de Rtg2p que é requerida para o crescimento celular. No ensaio de longevidade replicativa os mutantes E106A, R109E, E137A, T138A e $D 158 A$, apresentaram longevidade similar à da cepa $r \operatorname{tg} 2 \Delta$, enquanto os mutantes $L 56 G$ e G161A apresentaram longevidade média superior ao valor da cepa WT. Em conclusão, os resultados obtidos demonstram que o domínio N-terminal é muito importante para a função de Rtg2p, tanto em termos de longevidade, bem como na sinalização retrógrada; também indicam que existem determinantes estruturais que controlam a longevidade de forma dependente ou independente da resposta retrógrada.

Palavras-chave: Rtg2p. DRCN. Saccharomyces cerevisiae. Envelhecimento. Sinalização retrograda. 


\begin{abstract}
RIOS-ANJOS, R.M. Structural mapping of Rtg2p determinants involved in retrograde signaling and aging of Saccharomyces cerevisiae. 2016. 97 p. Masters thesis (Biotechnology) - Instituto de Ciências Biomédicas, Universidade de São Paulo, São Paulo, 2016.
\end{abstract}

In Saccharomyces cerevisiae, $\operatorname{Rtg} 2 \mathrm{p}$ is a protein involved in the retrograde signaling, a pathway of communication from mitochondria to nucleus. When bound to the negative factor Mks1p, Rtg2p allows translocation of the Rtg1/3p complex from the cytoplasm to the nucleus, to activate the transcription of nuclear genes in response to mitochondrial dysfunction. In addition to its role in retrograde response, $R \operatorname{tg} 2 p$ has been associated with longevity, because cells with disrupted $R T G 2$ gene ( $r$ tg24) have decreased longevity. Rtg2p has a N-terminal domain important for its function that is related to retrograde signaling and aging in yeast, but no detailed structural mapping was performed on this protein to date. The goal of this study was to identify the structural determinants of Rtg2p, controlling the function of this protein in retrograde response and aging. For this purpose thirteen point mutants were produced ( $L 56 G$, E106A, E106H, R109E, N113A, E137A, D158A, T138A, A160G, G161A, S163A, Q165A, $Q 165 E)$ by site-directed mutagenesis, using rational design by decomposition of residues correlation networks (DRCN). Retrograde signaling was analyzed by glutamate auxotrophy and CIT2 gene expression, and replicative life span assays were performed to measure longevity in all strains. We highlight the strains $N 113 \mathrm{~V}$ and $Q 165 \mathrm{~A}$ that showed no glutamate auxotrophy and higher expression of CIT2 compared to rtg2 4 strain. The E137A strain had a lower growth performance with the addition of glutamate compared to others strains, which possibly indicates that this mutation affects a Rtg2p activity required for cell growth. In replicative life span assays the strains E106A, R109E, E137A, T138A, and D158A showed longevity equal to $r \operatorname{tg} 2 \Delta$ strain, while $L 56 G$ and $G 161 A$ had average lifespan exceeding WT. In conclusion, our results demonstrate that the $\mathrm{N}$-terminal domain is very important to the function of $\operatorname{Rtg} 2 \mathrm{p}$, both in longevity and retrograde response, and also show there are structural determinants in Rtg2 $p$ that control longevity in both dependent or independent manner of the communication between mitochondria and nucleus.

Keywords: Rtg2p. DRCN. Saccharomyces cerevisiae. Aging. Retrograde signaling. 


\section{LISTA DE FIGURAS}

Figura 1 - Envelhecimento replicativo em levedura.................................................. 19

Figura 2 - Envelhecimento cronológico em levedura...................................................... 21

Figura 3 - Representação esquemática da sinalização retrógrada................................... 25

Figura 4 - Reconfiguração metabólica em células deficientes respiratórias.................... 26

Figura 5 - Esquema da Mutagênese sítio dirigida por sobreposição de produtos de PCR.

Figura 6 - Esquema de uma placa YPD para ensaio de longevidade replicativa.

Figura 7 - Método de perturbação estatística para medir acoplamentos entre resíduos de proteínas

Figura 8 - Modelo de Rtg2p obtido pelo servidor Robetta

Figura 9 - Modelo de Rtg2p, com os domínios em cores diferenciadas.

Figura 10 - Localização dos resíduos das comunidades obtidas por DRCN no modelo de Rtg2p.

Figura 11 - Localização na estrutura tridimensional de Rtg2p dos resíduos com conservação superior a 90\% na análise DRCN da família PF02541.

Figura 12 - Motivos de ligação ao ATP indicado no N-terminal da estrutura tridimensional de Rtg2p.

Figura 13 - Resíduos para mutagênese sítio-dirigida no N-terminal de Rtg2p............... 60

Figura 14 - Rompimento do gene RTG2 com o cassete rtg2::URF13-KanMX............... 62

Figura 15 - Substituição gênica de rtg2::URF13-KanMX pelos mutantes pontuais de $R T G 2$ 64

Figura 16 - Mutações pontuais em Rtg2p causam auxotrofia para glutamato. 65

Figura 17 - Mutantes pontuais em Rtg2p causam prejuízo no crescimento. 67

Figura 18 - Mutantes pontuais de Rtg2p apresentam baixa expressão de CIT2-LacZ..... 70

Figura 19 - Deleção de $R T G 2$ reduz longevidade replicativa........................................... 71

Figura 20 - Mutações pontuais não comprometem longevidade replicativa da célula...... 72

Figura 21 - Mutações pontuais comprometem longevidade replicativa da célula............. 73

Figura 22 - Mutações pontuais aumentam longevidade replicativa da célula.................. 74

Figura 23 - Interação do ATP e $\mathrm{Mg}^{2+}$, no N-terminal de Rtg2p.................................... 79

Figura 24 - Resíduos do N-terminal de Rtg2p dividos em três regiões distintas.............. 81 


\section{LISTA DE TABELA}

Tabela 1 - Oligonucleotídeos utilizados na construção de mutantes pontuais de $R T G 2 \ldots . .33$

Tabela 2 - Matriz de autocorrelação da comunidade 1 da análise DRCN de Rtg2p.......... 45

Tabela 3 - Matriz de autocorrelação da comunidade 2 da análise DRCN de Rtg2p.......... 45

Tabela 4 - Matriz de autocorrelação da comunidade 3 da análise DRCN de Rtg2p.......... 45

Tabela 5 - Resíduos com conservação superior a 90\% na Família PF02541 ................... 47

Tabela 6 - Validação pelo Diagrama de Ramachandran dos modelos tridimensionais de Rtg2p obtidos em diferentes servidores................................................................. 48

Tabela 7 - Validação pelo Verify3D dos modelos tridimensionais de Rtg2p obtidos em

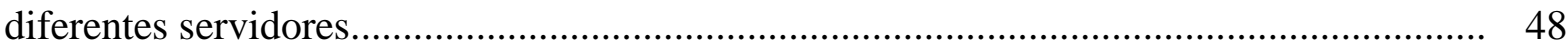

Tabela 8 - Hipóteses para interação dos resíduos conservados........................................ 55

Tabela 9 - Hipóteses de interação para os resíduos acoplados de Rtg2p......................... 59

Tabela 10 - Resíduos de aminoácido de Rtg2p que foram alterados por mutagênese

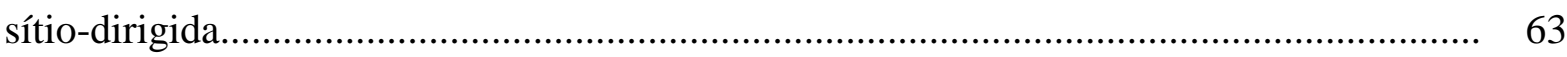




\section{LISTA DE ABREVIATURAS E SIGLAS}

Acetil-CoA Acetil Coenzima A

ATP Adenosina trifosfato

CEGH-CEL Centro de Pesquisas sobre o Genoma Humano e células-tronco

CLS Chronological Life Span

CoQ6 Coenzima Q6

DNA Ácido desoxirribonucleico

mtDNA DNA mitocondrial

DRCN Decomposition of Residues Correlation Networks

ERC Círculos extracromossomais

Kb Kilobases

kDa Kilodaltons

MAS Multiple Sequence Alignment

$\mathbf{M g}^{2+} \quad$ Íon Magnésio

mtDNA DNA mitocondrial

NAD+ Nicotinamida adenina dinucleótídeo

rDNA DNA ribossomal

PCR Reação em cadeia da Polimerase

ROS Reactice Oxigen Species

RLS Replicative Life Span

ONPG o-nitrofenil- $\beta$-D-galactopiranosídeo

SCA Statistical Coupling Analysis

TCA Tricarboxylic Acid Cycle 


\section{SUMÁRIO}

1 INTRODUÇÃ

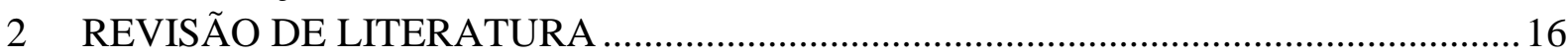

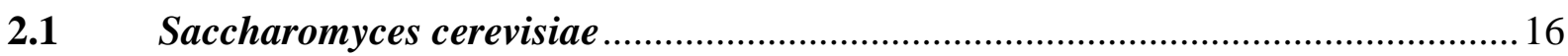

2.2 Saccharomyces cerevisiae como modelo de estudo de envelhecimento................ 17

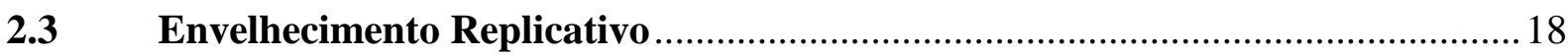

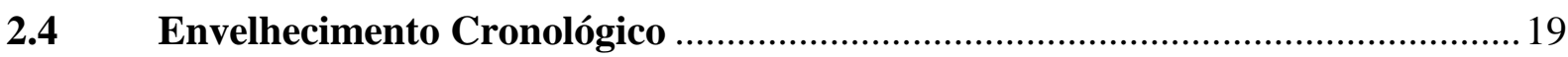

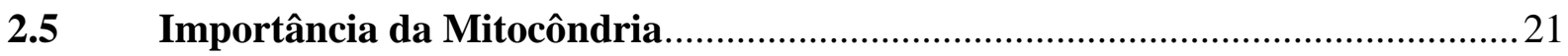

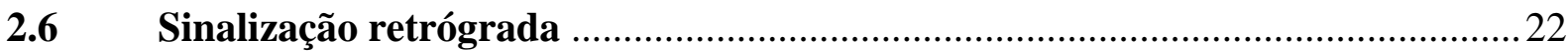

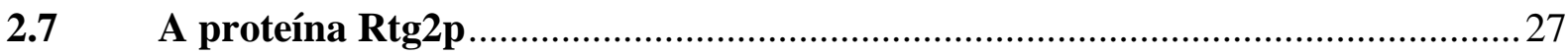

2.8 Decomposição de Redes de Correlações de Amino Ácidos (DRCN) ...................28

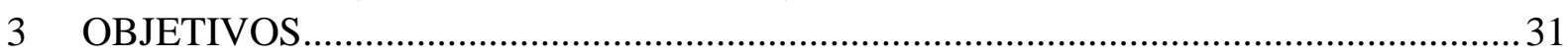

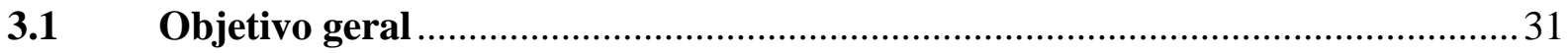

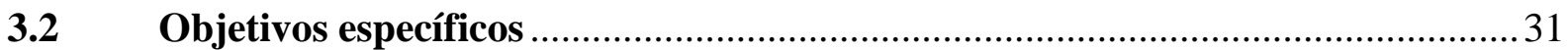

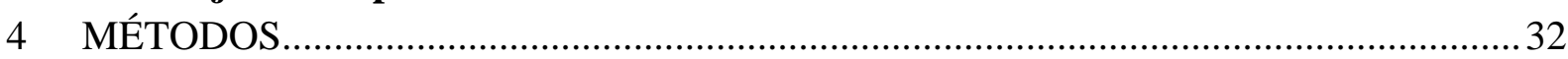

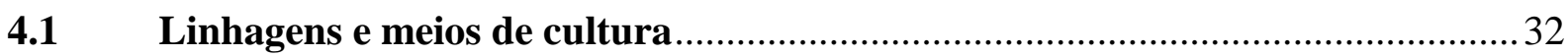

4.2 Manipulação de DNA e técnicas gerais de biologia molecular .......................... 32

4.3 Construção do cassete rtg2::URF13-KanMX ................................................. 34

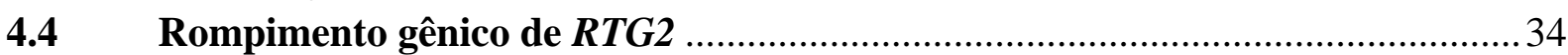

4.5 Confirmação do locus de integração do cassete $\operatorname{rtg2::URF13-KanMX~..............~} 35$

4.6 Construção dos mutantes por mutagênese sítio-dirigida .................................... 36

4.7 Clonagem dos mutantes no vetor pGEM-3Zf(+) ................................................. 38

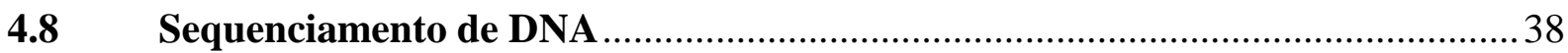

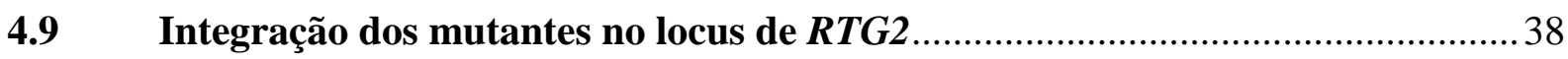

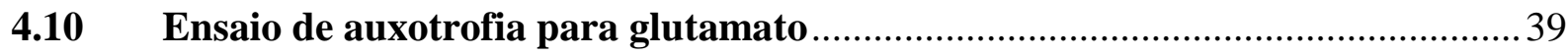

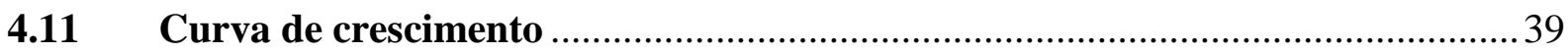

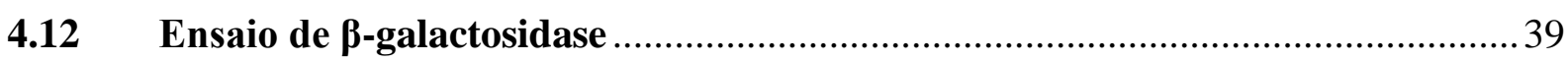

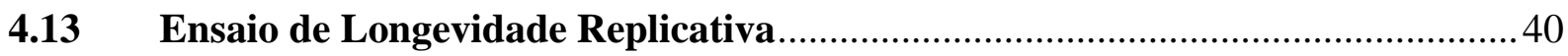

4.14 Decomposição de Redes de Correlação de Aminoácidos (DRCN) ......................4 41

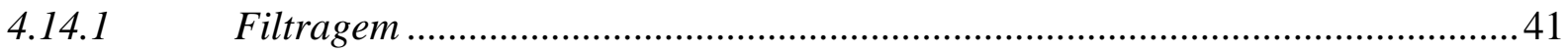

4.14.2 Perturbação estatística ...................................................................................... 42

4.14.3 Matrizes de autocorrelação e detecção de comunidades .................................... 43

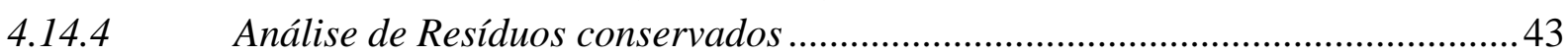

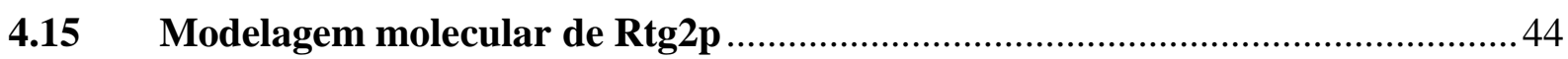

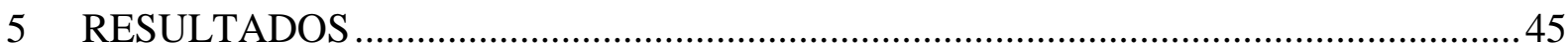

5.1 Decomposição de Redes de Correlações de Aminoácidos (DRCN) de Rtg2p .... 45

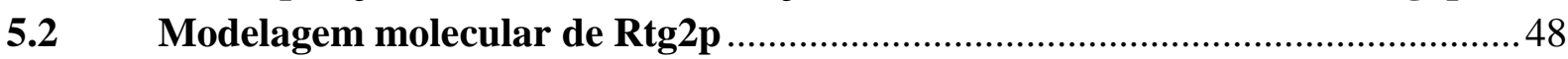

5.3 Hipótese das interações dos resíduos conservados e/ou coevoluídos na estrutura

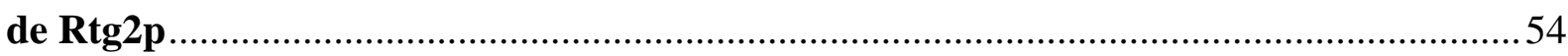

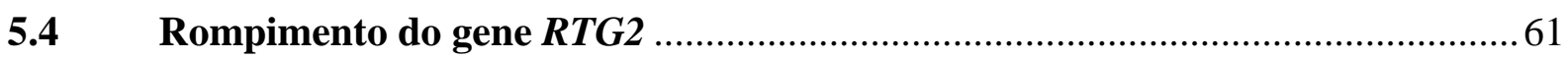

5.5 Clonagem dos mutantes pontuais de Rtg2p baseados na análise DRCN...........62

5.6 Substituição gênica dos mutantes no locus de RTG2 ….........................................64

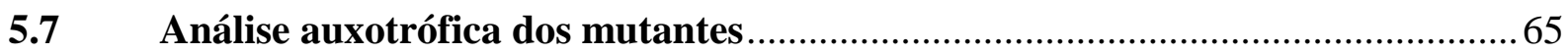


5.8 Análise da ativação da sinalização retrógrada dependente de Rtg2p ................69

5.9 Análise da Longevidade Replicativa dos mutantes de $R T G 2$............................. 71

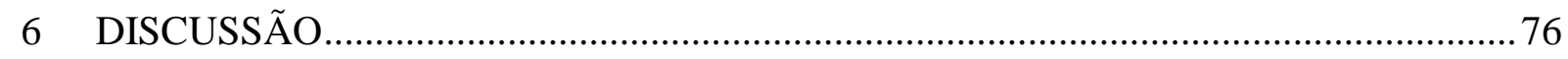

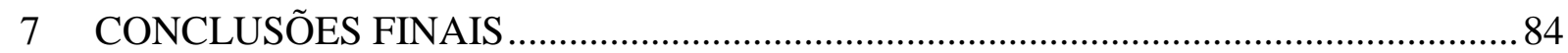

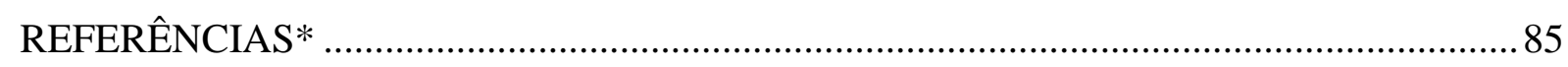

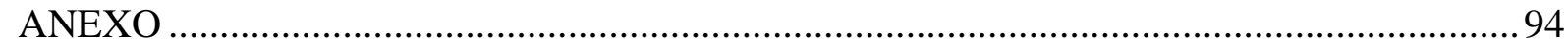




\section{INTRODUÇÃO}

Envelhecimento é um processo que pode ser definido como um declínio funcional vinculado ao tempo, levando à incapacidade da célula resistir aos fatores ambientais, e, consequentemente, à diminuição das taxas de sobrevivência e reprodução com o aumento da idade e por fim à morte (FLATT; SCHMIDT, 2009). Ou seja, envelhecimento é a incapacidade do organismo manter a homeostase (YU, 1996). Além disso, sabe-se que o envelhecimento está associado a parâmetros interrelacionados, tais como genética, taxa metabólica, ingestão calórica, estilo de vida e fatores ambientais (SCHÖNEICH, 1999).

Devido à grande comp0lexidade do envelhecimento e da dificuldade em se estudar tal processo, não existe um consenso sobre a cascata de eventos que o explique. Atualmente existem mais de trezentas teorias que procuram explicar seu mecanismo, o que levou ao acúmulo, ao longo do tempo, de um grande número de publicações sobre o envelhecimento, relacionadas a parâmetros bioquímicos, fisiológicos e patológicos (MCCLEARN, 1997; MEDVEDEV; IAA, 1990). Assim, o que sabemos sobre o envelhecimento é restrito, mas já conhecemos alguns genes que influenciam no aumento ou diminuição da longevidade dos organismos.

Biologicamente, há uma tentativa em elucidar os fatores primários responsáveis pela cascata de eventos complexos que causam o envelhecimento em humanos. Contudo, esses estudos são limitados devido ao tempo de geração da espécie. Todavia, já se tem estabelecido alguns organismos-modelo para esse tipo de estudo, entre eles, a levedura Saccharomyces cerevisiae, o nematodo Caenorhabditis elegans, o invertebrado Drosophila melanogaster e o mamífero Mus musculus, todos com o tempo de vida relativamente curto.

Podemos destacar desses S. cerevisiae, que apresenta características ainda mais relevantes para este tipo de estudo, uma vez que está levedura é de fácil manipulação, seu genoma está completamente sequenciado, possui tempo de vida relativamente curto, vários genes ortólogos em comum com humanos, além de vias metabólicas conservadas e dois modelos para análise do envelhecimento (PETRANOVIC; NIELSEN, 2008). 


\section{REVISÃO DE LITERATURA}

\subsection{Saccharomyces cerevisiae}

As leveduras já eram utilizadas pelo homem há mais de 6.000 anos antes de Cristo, sendo utilizadas na Suméria e na Babilônia. Em paralelo, cepas de S. cerevisiae eram empregadas na produção de vinho na Georgia e para fermentação de massas no Egito antigo. Apesar disso, sua caracterização se deu apenas em 1837, por Meyen, que descobriu um fungo unicelular no malte empregado na produção de cerveja (FELDMANN, 2012).

A levedura foi introduzida como um organismo experimental em meados 1930 por Hershel Roman (FELDMANN, 2012), porém após experimentos genéticos realizados por Fred Sherman nos anos de 1960 e 1970, com estudos sobre a estrutura de genes e os efeitos de mutações em proteínas, $S$. cerevisiae se tornou um sistema-modelo e desde então tem recebido cada vez mais atenção por diversos pesquisadores de diferentes linhas de pesquisa (SHERMAN, 2002; FELDMANN, 2012).

S. cerevisiae tem sido utilizada como modelo de estudo para o entendimento da célula eucariótica há mais de meio século. Dentre 700 espécies conhecidas, S. cerevisiae destacou-se por ser um fungo unicelular que se divide por brotamento em um tempo curto e de fácil manipulação (SMITH; DUNCAN; MOIR, 1985; SHERMAN, 2002).

Dentre as vantagens em se trabalhar com S. cerevisiae, podemos destacar seu cultivo em meios de culturas definidos, a existência de técnicas de genética clássica bem estabelecidas para o trabalho com leveduras; seu ciclo de vida alternando entre as fases diploide e haploide, o fato de poder ser mantida em estado haploide para estudo; e as célulasmãe poderem ser separadas da progênie por micromanipulação (FELDMANN, 2012).

Devido à grande importância biológica, $S$. cerevisiae teve seu genoma totalmente sequenciado em 1996 por Goffeau e colaboradores, o que incentivou os estudos com levedura, representando um marco na história da biologia eucariótica. Ademais, é possível perceber que através do seu genoma obteve-se uma riqueza de informações sobre vários aspectos da organização genômica e evolucionária. O genoma de S. cerevisiae é relativamente pequeno, possuindo cerca de 6000 genes, e o DNA cromossômico possui $12.068 \mathrm{~kb}$, subdivididos em 16 cromossomos (DUINA; MILLER; KEENEY, 2014; GERSHON; GERSHON, 2000; GOFFEAU et al., 1996). 
Devido a esses fatores $S$. cerevisiae tem sido amplamente utilizada como um modelo de estudo em inúmeras áreas, entre elas, no estudo do envelhecimento.

\subsection{Saccharomyces cerevisiae como modelo de estudo de envelhecimento}

Estudos moleculares e genéticos sobre o envelhecimento vêm ganhando uma maior atenção, visto que essa área é um campo muito importante. Estudos de envelhecimento em mamíferos são limitados, uma vez que estes apresentam um longo ciclo de vida. A longevidade média de camundongos e ratos varia de 3 a 5 anos e primatas vivem até 40 anos, tornando assim mais difícil quantificar a longevidade, bem como os fatores que modulam este fenômeno (STEINKRAUS; KAEBERLEIN; KENNEDY, 2008). Estudar processos complexos relacionados ao envelhecimento em levedura mostra-se cada vez mais pertinente, devido a atributos que a faz muito atraente para a pesquisa biológica moderna (GERSHON; GERSHON, 2000).

Muitos estudos sobre envelhecimento em levedura elucidaram fatores importantes para o envelhecimento dos seres humanos. Até o presente momento ainda não foi demonstrado, mas evidências sugerem que, embora alguns aspectos do envelhecimento em leveduras sejam específicos para esse organismo, muitos dos mecanismos de regulação da longevidade foram evolutivamente conservados entre os eucariotos (KAEBERLEIN, 2010). Por compartilhar mecanismos biológicos do envelhecimento com os eucariotos, estudar aspectos relacionados ao processo de envelhecimento em células de levedura é um tema de interesse para inúmeros pesquisadores.

S. cerevisiae tornou-se um dos organismos-modelo mais importantes utilizados na pesquisa sobre o envelhecimento. Em comparação com outros sistemas, a relativa facilidade e rapidez com que a longevidade pode ser quantificada em levedura permitem o progresso rápido do estudo e a elucidação de vários mecanismos moleculares do envelhecimento neste organismo. É necessário ressaltar que a partir da quantificação da longevidade é possível identificar dezenas de fatores que a modificam.

Existem muitos estudos sobre questões relacionadas a longevidade em levedura; em uma busca no PubMed (http://www.pubmed.gov/) utilizando o termo "Yeast Aging" obtemos mais de 2.778 artigos publicados desde 1948, com aumento progressivo de publicações ao longo dos anos.

Com todo conhecimento nessa área, foram estabelecidos dois modelos para o estudo do envelhecimento em $S$. cerevisiae, o envelhecimento replicativo e envelhecimento 
cronológico (STEINKRAUS; KAEBERLEIN; KENNEDY, 2008). Estes dois modelos proporcionam a análise do envelhecimento sobre duas perspectivas diferentes, uma pelo número de células-filhas produzidas por uma célula-mãe até o momento em que se torna senescente, e a outra pelo tempo que a célula de levedura pode sobreviver num estado de quiescência, respectivamente.

\subsection{Envelhecimento Replicativo}

Em 1950, Barton percebeu que a célula-mãe acumulava cicatrizes a cada broto que produzia, e uma célula-filha não se formaria novamente do lado da cicatriz deixada. Com essas informações Mortimer e Johnston, em 1959, propuseram que S. cerevisiae possuía um limite no número de gerações e com isso sua longevidade poderia ser calculada a partir do número de brotos produzidos. Com isso, o número de brotos passou a ser a contagem de gerações e, a análise do brotamento de uma população de células tornou-se um método para medir a longevidade, nomeado como envelhecimento replicativo (do inglês "Replicative Life Span”, RLS) (Figura 1).

O envelhecimento replicativo é medido pela remoção física de células-filhas que uma célula-mãe consegue produzir em sua fase exponencial de crescimento, que são facilmente distinguidas a cada geração das células-mãe, sob um microscópio óptico equipado com um micromanipulador (BARTON, 1950; KIM et al., 2004; LONGO; FABRIZIO, 2011; MORTIMER; JOHNSTON, 1959). Apos atingir um número limitado de divisões, a célula entra em um estado pós-replicativo curto, seguido de lise.

Mesmo após o trabalho inicial de Mortimer, os estudos com esse modelo de envelhecimento não alcançou notoriedade até o início de 1990, quando este sistema juntamente com novas metodologias foram utilizados para iniciar a identificação de genes e mecanismos moleculares que modulam a longevidade replicativa de S. cerevisiae. Quase 100 genes foram identificados, entre esses genes podemos destacar um dos mais importantes, SIR2, que codifica uma proteína desacetilase de histona dependente de $\mathrm{NAD}^{+}$. SIR2 foi associada ao envelhecimento replicativo em 1999, em um trabalho onde a sua superexpressão ajudou a estender a longevidade replicativa em S. cerevisiae (KAEBERLEIN; MCVEY; GUARENTE, 1999). A partir desse estudo foi possível elucidar os mecanismos de ação desse gene na RLS. Acredita-se que a extensão da longevidade ocorra pela atividade de Sir2p na supressão de círculos extracromossomais (ERC) de rDRN, estas moléculas de DNA circular são auto-replicantes e formam segregados para a célula-mãe durante a divisão celular 
(SINCLAIR; GUARENTE, 1997). O acúmulo de ERC limita a RLS das células-mãe, além disso, células sir2 24 apresentam vários danos oxidativos, que podem ser suprimidos pela superexpressão de Hsp104, uma chaperona envolvida na remoção de agregados proteicos. Células com a ausência de Sir2p e a superexpressão de Hspl04 tem o aumento no tempo de vida replicativo (ERJAVEC et al., 2007). A partir desses estudos vários outros foram realizados utilizando esse modelo para quantificar o envelhecimento em $S$. cerevisiae (JANKE et al., 2004; KAEBERLEIN, 2009; KRUEGEL et al., 2011; MOLIN et al., 2011; SMITH et al., 2008; STEFFEN; KENNEDY; TAYLOR; DILLIN, 2011).

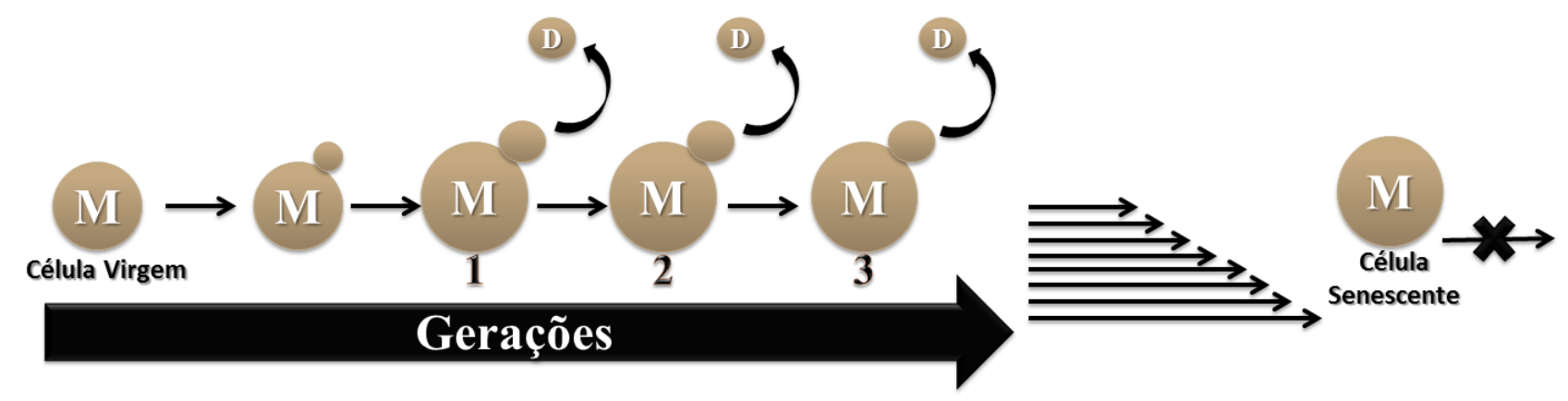

Figura 1 - Envelhecimento replicativo em levedura. A partir de uma célula-mãe (M) é medida a longevidade de acordo com o número de célula-filha (D), ou seja, o número de células-filhas que uma mãe pode produzir até se tornar uma célula senescente.

\subsection{Envelhecimento Cronológico}

Leveduras e outros microrganismos evoluíram para sobreviver em condições adversas comumente encontradas na natureza. $\mathrm{Na}$ verdade, a maioria dos microrganismos são capazes de sobreviver em uma fase estacionária sob baixo fornecimento de nutrientes (BRAUN et al., 1996). Células selvagens de levedura são capazes de sair da fase estacionária apenas nos períodos em que todos os nutrientes necessários para o crescimento tornam-se disponíveis no meio. Sabendo-se disso, foi desenvolvido um método onde é possível medir o tempo em que uma população de células permanece viável, após atingir a fase estacionária (FABRIZIO; LONGO, 2003).

O Envelhecimento cronológico (do inglês "Chronological Life Span”, CLS) é um modelo de envelhecimento das células pós-mitóticas, que é definido pelo tempo que a célula de levedura pode permanecer em um estado de quiescência, ou seja, é a fase onde a célula não 
recebe estímulos para divisão e permanece exercendo suas funções vitais. Nesse modelo é medida a capacidade de retornar o crescimento mitótico ao longo do tempo (Figura 2) (KAEBERLEIN, 2010).

CLS é medido tipicamente por crescimento de uma cultura de células de levedura até o estado pós-diauxico, onde a maioria das células sai do ciclo celular. A fase de pós-diauxica inicia-se após um período de 24 horas, quando esgota-se a glicose do meio e ocorre uma alternação do metabolismo fermentativo para um modo respiratório, dependente do etanol gerado durante a fermentação (WERNER-WASHBURNE et al., 1993). Quando o etanol se esgota, as células entrarem na fase estacionária, então inicia-se o ensaio com células em fase $\mathrm{G}_{0}$. O ensaio CLS foi desenvolvido para complementar o ensaio RLS, proporcionando a capacidade de reproduzir o envelhecimento de organismos multicelulares (FABRIZIO; LONGO, 2003; LONGO; FABRIZIO, 2011; LONGO; GRALLA; VALENTINE, 1996). Assim como no ensaio replicativo, o ensaio cronológico também possibilitou a elucidação de vários mecanismos de envelhecimento em $S$. cerevisiae, e isso permitiu conhecer duas grandes vias pró-envelhecimento cronológico em $S$. cerevisiae, as quais seguem relacionadas com a disponibilidade de nutrientes e o controle da sua utilização.
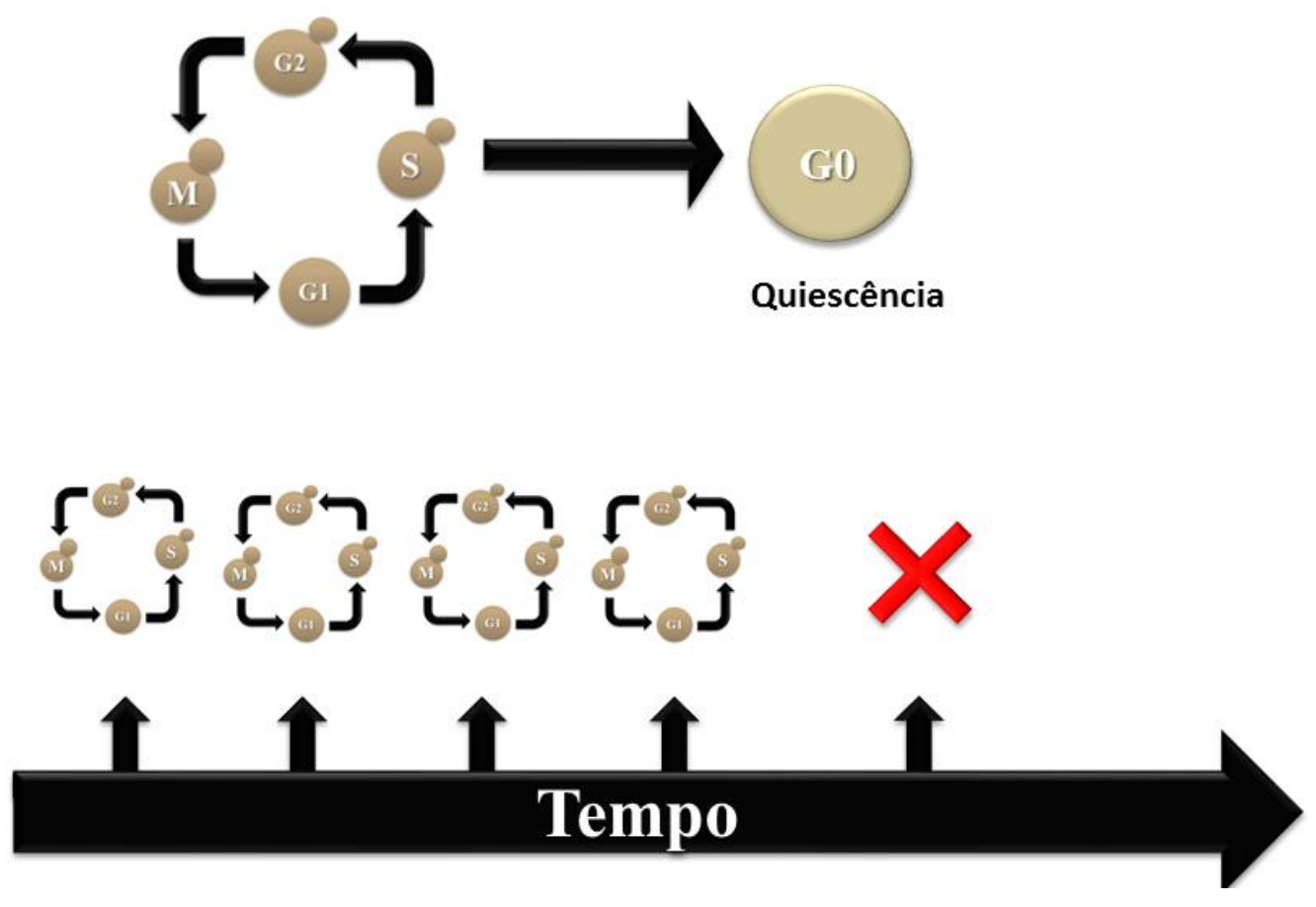

Figura 2 - Envelhecimento cronológico em levedura. O envelhecimento é medido como o tempo em que a célula pode se manter viável no estado quiescente $\left(\mathrm{G}_{0}\right)$, medindo-se, após esse período, sua capacidade para proliferar, quando é fornecido um meio rico em nutrientes. 
Ambos os modelos de envelhecimento (CLS e RLS) são de extrema importância para análise do envelhecimento em levedura, e através deles foi possível determinar a importância de alguns genes para a longevidade em S. cerevisiae. Envolvidas nos mecanismos elucidades por esses modelos, uma organela mostrou-se um elemento essencial para a longevidade da célula, pois desempenha um papel fundamental na produção da maior parte dos compostos fosfatados primordiais para o balanço energético da célula, a mitocôndria (NICHOLLS, D ; LOCKE, 1984).

\subsection{Importância da Mitocôndria}

De acordo com a teoria endossimbiótica de Lynn Margulis, há bilhões de anos, uma célula anaeróbica primitiva, com núcleo prematuro diferenciado, obtendo energia exclusivamente da via glicolítica, englobou uma $\alpha$-protobactéria capaz de utilizar o oxigênio de uma atmosfera em que este gás começava a ser abundante (MARGULIS, 1980). A simbiose entre os dois organismos iniciou o que, gradualmente, permitiu o surgimento das mitocôndrias das células eucarióticas.

As mitocôndrias são organelas essenciais, cuja função primária é a síntese de ATP, por meio da fosforilação oxidativa. O seu tamanho, similar ao de uma célula bacteriana, e o fato de possuírem o próprio DNA, permitiram sugerir a teoria endossimbiótica. Contudo, comparando-se os genomas das atuais mitocôndrias com os das bactérias, observa-se que enquanto o tamanho médio do genoma das primeiras está na ordem de kilobases de DNA o das segundas está na ordem de megabases (ANDERSSON et al., 2003).

Como conciliar esse fato com a teoria endossimbiótica? Uma teoria proposta foi a de que, ao longo da evolução, o DNA mitocondrial (mtDNA) foi exportado em grande parte para o núcleo da célula, deixando apenas o necessário à síntese de algumas proteínas envolvidas na fosforilação oxidativa, então, a partir, disso a simbiose entre esses organismo se estabeleceu (Margulis, 1985). Essa transferência do mtDNA permitiu o surgimento de duas vias: a via anterógrada, que consiste na transferência de informação do núcleo para a mitocôndria, e a sinalização retrógrada, que corresponde à sinalização da mitocôndria para o núcleo (BUTOW; AVADHANI, 2004).

Sinalização retrógrada é uma via na qual a expressão de genes nucleares é alterada em células com atividade mitocondrial reduzida, ou seja, quando a mitocôndria está disfuncional (PARIKH et al., 1987). 
Além do processo respiratório, o papel da mitocôndria no envelhecimento de $S$. cerevisiae está associado com o aumento do estresse oxidativo que é o acumulo de espécies reativas de oxigênio (do inglês "Reactice Oxigen Species", ROS) que causam danos estruturais as proteínas, lipídeos e outros componentes celulares, e isto está associado com deficiência na função mitocondrial e com apoptose (morte celular programada) (JAZWINSKI, 1996). Nestas condições as células de $S$. cerevisiae são capazes de se adaptar ao estado funcional de suas mitocôndrias, ativando a sinalização retrógrada.

\subsection{Sinalização retrógrada}

Em S. cerevisiae, o DNA mitocondrial é dispensável para o crescimento, desde que ocorra numa fonte de carbono fermentável, como a glicose, proporcionando um sistema experimental para a análise da resposta celular às alterações do estado funcional das mitocôndrias (EPSTEIN et al., 2001).

Em 1987 foi realizada a primeira tentativa de entender os efeitos do DNA mitocondrial (mtDNA) sobre a expressão de genes nucleares, observando que a transcrição de diversos genes nucleares é aumentada em cepas com deficiências respiratórias causadas por danos em seu genoma mitocondrial (PARIKH et al., 1987).

A partir disso, estabeleceu-se, a princípio, a existência de uma via de transmissão de sinal das mitocôndrias para genes nucleares alvo, a sinalização retrógrada (PARIKH et al., 1987). Liao e colaboradores (1991) verificaram que células selvagem com o DNA mitocondrial intacto $\left(\rho^{+}\right)$tinham expressão basal do gene $C I T 2$, que codifica a citrato sintase peroxissomal (que catalisa o primeiro passo do ciclo do glioxilato). Entretanto, em células com ausência de mtDNA ( $\rho^{\circ}$ petites), a expressão do gene CIT2 é aumenta de 30 a 40 vezes. Assim foi possível verificar que a expressão de CIT2 é controlada pela atividade da mitocôndria. Com isso, a ativação transcricional deste gene tornou-se um diagnóstico para estudos da resposta retrograda e foi utilizada na série de trabalhos que elucidou seu mecanismo, como descrito a seguir (LIAO et al., 1991).

Identificaram-se dois elementos cis-atuantes de $76 \mathrm{pb}, \mathrm{UASr}$, no promotor de CIT2, aos quais se ligam as proteínas responsáveis pela ativação transcricional, sendo Rtg1p e Rtg3p, fatores de transcrição do tipo zíper de leucina básico hélice-alça-hélice (bHLH-Zip) (JIA et al., 1997; LIAO; BUTOW, 1993) que reconhecem o sítio GTCAC desse elemento. Rtg1p e Rtg3p formam um heterodímero capaz de ativar a transcrição, pois possuem resíduos de aminoácidos básicos (histidina e arginina) conservados nessa classe de ativadores (JIA et 
al., 1997). É provável que Rtg1p facilite a ligação de Rtg3p ao UASr, pois o domínio de ativação transcricional do complexo está localizado somente na proteína Rtg3p, nas porções N- e C-terminal (Figura 3) (ROTHERMEL; THORNTON; BUTOW, 1997).

Essa forte associação entre Rtg1p e Rtg3p também é observada no citoplasma, onde ambas proteínas se localizam, quando a sinalização retrógrada não está ativada. O rompimento do gene RTG1 possibilita um melhor entendimento da função do mesmo, pois quando inativado, a localização celular de $\operatorname{Rtg} 3$ p se dá constitutivamente nuclear, com isso indicando que Rtg1p tem um papel duplo: ativar a transcrição e sequestrar Rtg3p no citoplasma (SEKITO; THORNTON; BUTOW, 2000).

Para a ativação da resposta retrograda é necessário uma proteína para a translocação do complexo Rtg1p/Rtg3p do citoplasma para o núcleo, essa proteína é denominada Rtg2p. Ela atua a montante (upstream) do complexo transcricional formado por $\operatorname{Rtg} 1 \mathrm{p} / \operatorname{Rtg} 3 \mathrm{p}$, sendo, simultaneamente, sensor da disfunção mitocondrial e transmissor dos sinais mitocondriais que permitem o complexo Rtg1/3p ativar a transcrição de seus genes-alvo. Nas cepas em que o gene $R T G 2$ foi rompido, $\operatorname{Rtg} 3$ p é hiperfosforilada e permanece no citoplasma sem traduzir o sinal mitocondrial (SEKITO; THORNTON; BUTOW, 2000). O controle por fosforilação e sequestro citoplasmático é o mecanismo primário de regulação da sinalização retrógrada, também encontrado na regulação de diversos transativadores de levedura, exceto por Rtg2p, cuja função específica é completamente desconhecida (BUTOW; AVADHANI, 2004b; LIU; BUTOW, 2006).Rtg2p tem características moleculares de uma exopolifosfatase, incluindo um domínio de ligação ao ATP no N-terminal, cuja integridade é essencial para sua função (LIU et al., 2003). Esse domínio é similar ao encontrado na superfamília das proteínas que se ligam ao ATP (KOONIN, 1994).

O principal modulador negativo da sinalização retrógrada é a proteína Mks1p, a qual foi encontrada a partir de abordagens genéticas por vários laboratórios (CHEN; POWERS, 2002; DILOVA; SEKITO et al., 2002; LIU et al., 2001; TATE et al., 2002). Em células contendo o gene $M K S 1$ rompido (mks1 1 ), a resposta retrógrada de CIT2 é alta, independente de Rtg2p, e não é afetada por glutamato. Os genes RTG regulam a expressão de CIT2 e também a de CIT1, ACO1, IDH1 e IDH2 (LIU; BUTOW, 1999), que codificam enzimas que catalisam as três primeiras etapas do ciclo do ácido cítrico (do Inglês "Tricarboxylic Acid Cycle", TCA) que conduzem à síntese de $\alpha$-cetoglutarato, o precursor de glutamato. Glutamato é precursor de uma série de aminoácidos e de glutamina, que é precursora das purinas e pirimidinas (Figura 4) (BUTOW; AVADHANI, 2004; EPSTEIN et al., 2001). 
Rtg2p e Mks1p são proteínas que estão em constante associação dinâmica, em resposta aos níveis de glutamato e à função mitocondrial (LIU et al., 2003). Quando associada a Rtg2p, a proteína Mks1p é inativada e desfosforilada parcialmente. Na presença de glutamato, ou em altos níveis de atividade da mitocôndria, Mks1p desassocia-se de Rtg2p, torna-se altamente fosforilada e, em seguida, associa-se às proteínas 14-3-3 Bmh1p e Bmh2p (VAN HEUSDEN et al., 1995) para inibir a translocação do complexo Rtg1/3p (Figura 3).

Estudos posteriores mostraram que Mks1p e Rtg2p podem interagir na ausência de outros fatores, compondo a chave binária mínima para o controle da sinalização retrógrada. No mesmo trabalho, experimentos de gel filtração com extratos celulares mostraram que ambas as proteínas estão presentes em complexos de alto peso molecular in vivo (FERREIRA et al., 2005). Em particular, Mks1p pode ser detectada em dois complexos moleculares de tamanhos distintos: um de $900 \mathrm{kDa}$, na ausência de glutamato, e outro de $650 \mathrm{kDa}$, quando a via retrógrada é inibida na presença de glutamato. Rtg2p também apresenta distribuição bimodal entre dois complexos com pesos estimados de 650 e $440 \mathrm{kDa}$. É possível que a mudança organizacional dessas proteínas possa refletir grandes alterações conformacionais em resposta ao sinal mitocondrial da sinalização retrógrada. 


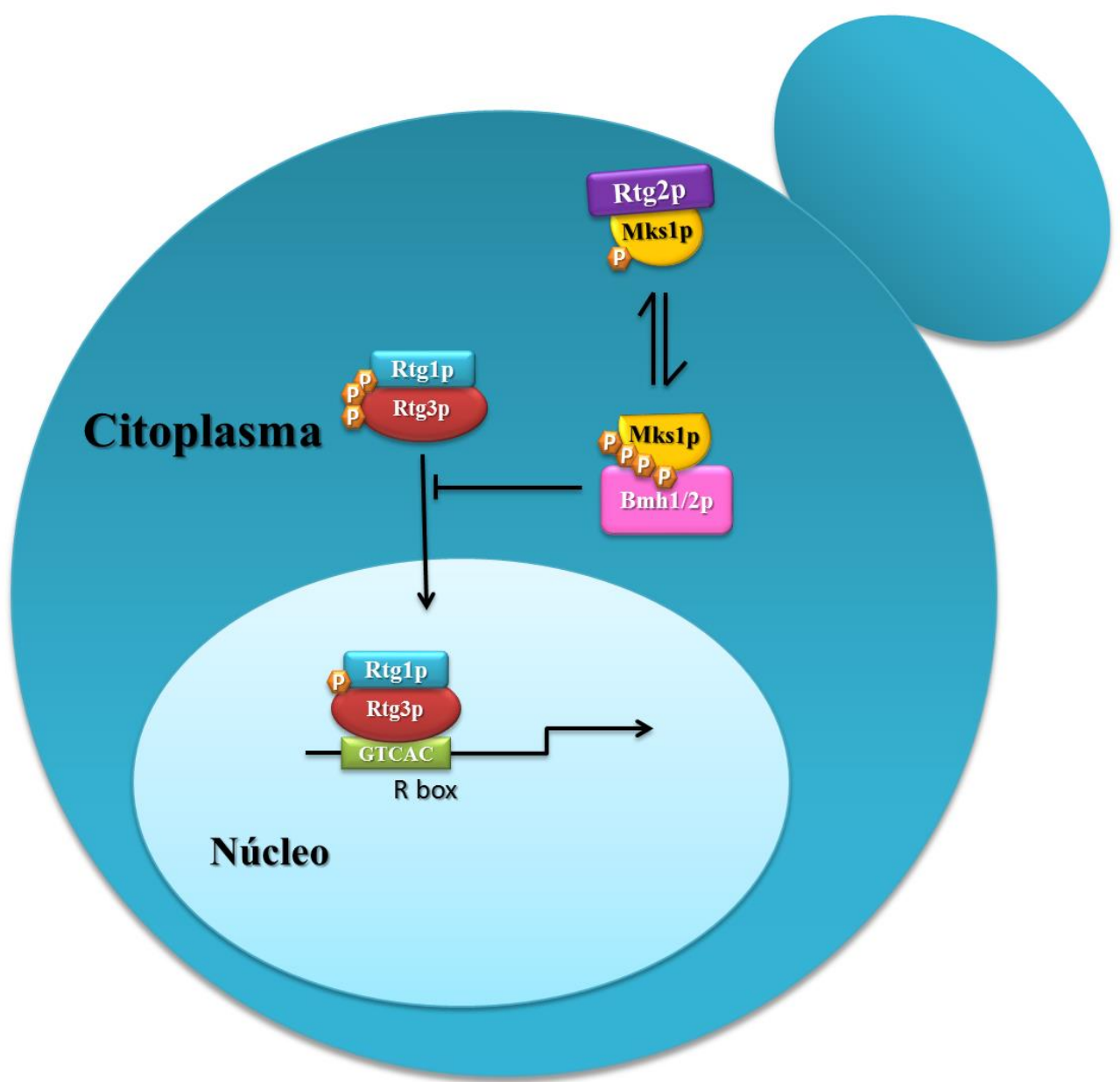

Figura 3 - Representação esquemática da sinalização retrógrada. A sinalização retrógrada controla a localização celular do complexo formado pelos fatores de transcrição Rtg1p e Rtg3p. Altos níveis de glutamato (ou atividade mitocondrial robusta) permitem que Mks1p se liberte de Rtg2p, seja fortemente fosforilada e liguese às proteínas 14-3-3, Bmh1p e Bmh2p. O complexo Mks1p-Bmh1/2p possui atividade inibitória que promove o sequestro dos transativadores para o citoplasma e a fosforilação de Rtg3p. Em células com baixos níveis de glutamato, ou com disfunção mitocondrial, a via é ativada e tais sinais são transmitidos por Rtg2p, que se associa à forma pouco fosforilada de Mks1p, possibilitando que o complexo Rtg1/3p migre para o núcleo.

O conjunto desses trabalhos indica que a sinalização retrograda detecta duas alterações na célula, a disfunção mitocondrial e os baixos níveis de glutamato, assim ativando as transcrições dos genes no núcleo celular. Em altos níveis de glutamato, a via é reprimida, e isso ocorre mesmo com atividade mitocondrial baixa na presença de glutamato extracelular. Para isso a célula, de alguma forma, "percebe" essa alteração nos níveis do glutamato adicionado ao meio de cultura, por meio do sensor de aminoácidos (SPS) na membrana plasmática. O sensor SPS é constituído de uma proteína análoga a um transportador de aminoácidos Ssy1p, um sensor de aminoácidos na membrana plasmática, e pelo menos duas proteínas da membrana periféricas, Ptr3p e Ssy5p, que associam-se a Ssy1p, permitindo que seja ativada uma cascata de transmissão de sinal em resposta aos aminoácidos externos e internos (FORSBERG et al., 2001). A inativação do SPS resulta na expressão elevada CIT2, logo, mesmo após adição de glutamato ao meio de cultura não se inibe a via, e a transcrição 
dos genes RTG-dependentes não é reprimida (LIU et al., 2001). Isso sugere a participação deste sensor na inibição da sinalização retrógrada na presença de excesso de glutamato, tanto intracelular produzido na ativação da resposta retrógrada quanto adicionado ao meio de cultura, já que o SPS pode responder a sinais intracelulares e extracelulares.

Qual o papel da sinalização retrograda na fisiologia de S. cerevisisae? Todos os genes ativados pela via RTG em resposta à disfunção mitocondrial levam à produção de AcetilCoA, tanto na mitocôndria quanto no peroxissomo, organelas que produzem citrato. O citrato do peroxissomo migra para a mitocôndria, onde, nos primeiros passos do TCA leva à produção de $\alpha$-cetoglutarato, que é o precursor de glutamato. O glutamato é o precursor de uma série de aminoácidos e de glutamina que é precursora das purinas e pirimidinas. Então, a sinalização retrógrada é ativa em uma célula com a mitocôndria disfuncional para promover a biogênese para se replicar, assegurando assim, que a replicação da célula irá ocorrer mesmo em uma atividade mitocondrial baixa, quando poderia haver poucos precursores biossintéticos para a replicação celular (LIU; BUTOW, 2006).

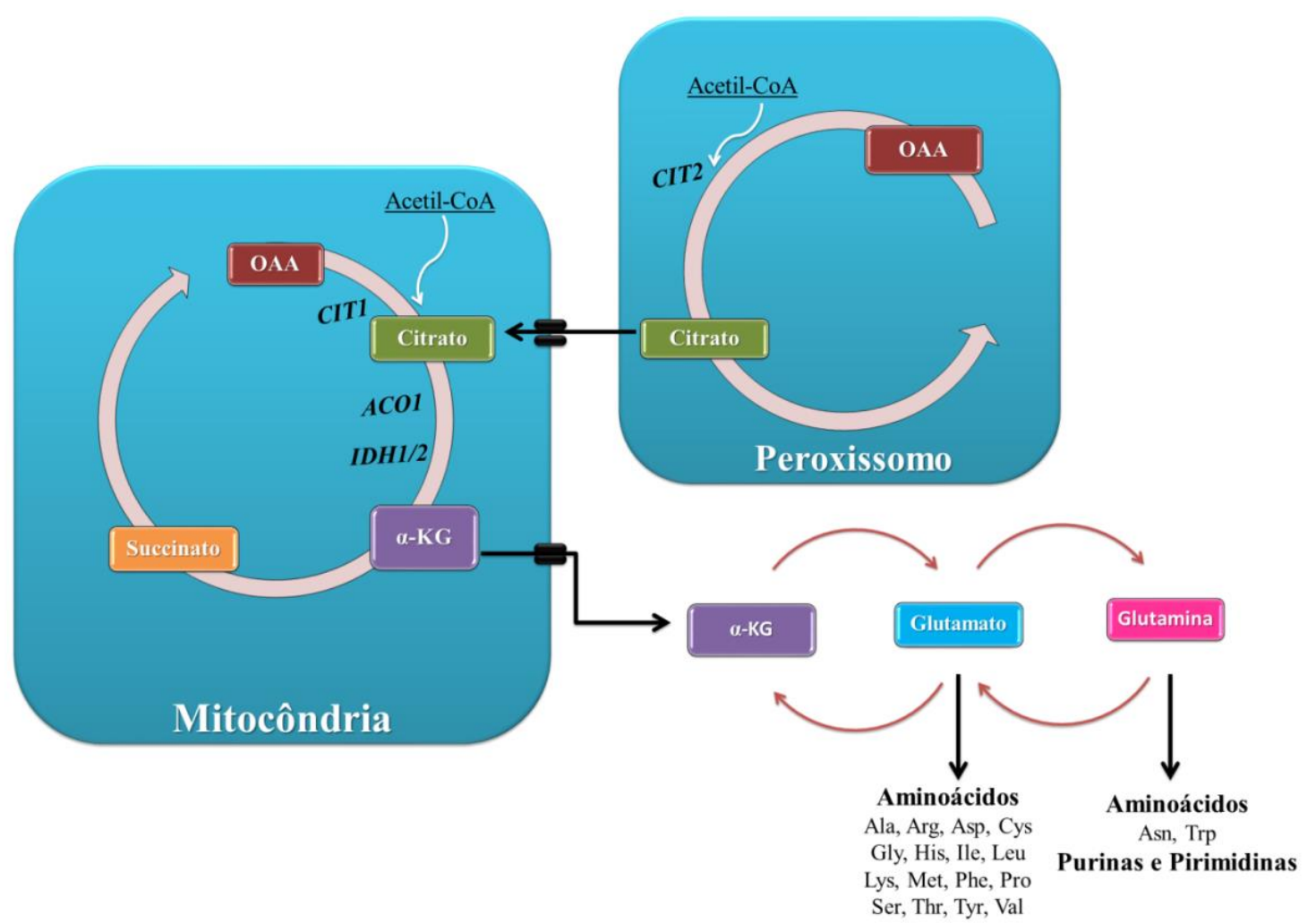

Figura 4 - Reconfiguração metabólica em células deficientes respiratórias. Apenas os genes envolvidos na biossíntese de glutamato controlados pelos genes RTG estão indicados em negrito. A expressão desses genes garante um nível suficiente de $\alpha$-cetoglutarato para a síntese de glutamato, para atender a demandas celulares que permitem a manutenção e replicação das células. 


\subsection{A proteína Rtg2p}

A proteína Rtg2p é o sensor proximal da atividade mitocondrial que permite o deslocamento do complexo Rtg1/3p para o núcleo. O mecanismo pelo qual Rtg2p controla a localização celular de Rtg1/3p ainda não é conhecido. Estudos têm apontado que Rtg2p possa ser uma fosfatase que desfosforila tanto Rtg3p quanto Mks1p. Essa hipótese é apoiada pelo fato do domínio N-terminal de Rtg2p ser similar ao de exopolifosfatases, proteínas que hidrolisam cadeias de polifosfato inorgânico, o qual é importante na regulação de diversas atividades celulares (WANG et al., 2003; ZHANG et al., 2005). Além disso, mutantes neste domínio N-terminal são incapazes de transmitir os sinais mitocondriais da sinalização retrógrada (LIU et al., 2003).

Além do papel fundamental na resposta retrógrada, Rtg2p possui outros papéis ainda não elucidados completamente, entre eles um envolvimento na longevidade, pois células com o gene $R T G 2$ rompido $(r t g 2 \Delta)$ apresentam longevidade reduzida, isto é, produzem menos células-filhas que a cepa selvagem (BARROS et al., 2004; KIRCHMAN et al., 1999). Isso pode estar relacionado com a supressão de formação de círculos de DNA extracromossomal ribossomal (ERC) realizado por Rtg2p, que se formam ao longo do envelhecimento das células de levedura (BORGHOUTS et al., 2004). Esse evento é importante porque quando esses círculos estão presentes em altos níveis podem matar as células. Rtg2p também foi encontrado no complexo transcricional SLIK, uma forma especializada do complexo SAGA, o qual tem atividade acetiltransferase de histonas, levando ao desempacotamento da cromatina. Provavelmente, a adição de Rtg2p a esse complexo expande seu repertório de regulação transcricional, incluindo genes da sinalização retrógrada e outros envolvidos no controle da longevidade (JAZWINSKI, 2005). Embora tenha sido mostrado que Rtg2p funciona como um componente essencial para a integridade estrutural do complexo SLIK, ainda não está bem elucidado sua atuação neste complexo (PRAY-GRANT et al., 2002).

Apesar do envolvimento de Rtg2p na sinalização retrógrada e no envelhecimento de $S$. cerevisiae ser muito estudado, nenhum trabalho foi realizado para identificar os determinantes estruturais desta proteína envolvidos nessas respostas. Uma forma de fazê-lo seria de mutagênese em resíduos de aminoácidos específicos, determinantes das atividades de Rtg2p. Contudo, isso requer a geração de um grande número de mutantes que poderiam ser

produzidos por PCR na presença de DNA polimerase com baixa atividade revisora. Recentemente surgiram métodos para o planejamento racional dos mutantes, dentre esses métodos destacam-se a análise por setores proteicos, que identifica grupos de resíduos 
coevoluidos, que representam uma organização estrutural de proteínas e reflete suas histórias evolutivas (BACHEGA et al., 2009; HALABI et al., 2009; TEŞILEANU; COLWELL; LEIBLER, 2015). Um segundo método identifica comunidades de resíduos correlacionados, onde é medida a correlação específica dos aminoácidos que pode ser usada para construir redes contendo todos os padrões de correlação e anti-correlação de uma família de proteínas (BLEICHER; LEMKE; GARRATT, 2011).

\subsection{Decomposição de Redes de Correlações de Amino Ácidos (DRCN)}

A observação de padrões de correlação em certas posições num alinhamento de múltiplas sequências de uma família de proteínas tem sido descrita, pelo menos, desde os anos 80. Porém, nos anos 90, esses padrões ganharam mais atenção, quando foram propostas uma variedade de métricas de correlação e, desde então, as mutações de resíduos correlacionados têm sido utilizadas para a busca de regiões de contatos nas proteínas, e, de fato, logo foi observado que duas posições que mostram forte correlação seriam provavelmente próximas na estrutura tridimensional da proteína, tal como proposto por Göbel em 1994 (GÖBEL et al., 1994).

A busca por conjuntos de posição coevoluídos também tem sido discutida desde o final dos anos 90. Atchley e colaboradores utilizaram um procedimento simples para encontrar posições que coevoluíram por meio de estimativas de informação mútua, definida como uma medida de correlação entre dois conjuntos de eventos (ATCHLEY; TERHALLE; DRESS, 1999).

No mesmo ano, uma métrica diferente de correlação posicional foi proposto por Lockless e Ranganathan, que sugeriu que grupos de resíduos correlacionados poderiam estar envolvidos na comunicação alostérica em famílias de proteínas. Esse método baseia-se na mecânica estatística de Boltzmann e é denominado análise por acoplamento estatístico (do Ingês, "Statistical Coupling Analysis", SCA), que quantifica conservação posicional e coevolução. No mesmo trabalho foi possível observar a correlação dos aminoácidos comparados com todos os outros da proteína, através do conceito de "perturbação", que mede a correlação entre as posições. Por exemplo, para um determinado alinhamento é possível identificar que a posição 25 e 45 são altamente correlacionadas, pois quando fixado um dado aminoácido na posição 25 a frequência do aminoácido da posição 45 é aumentada consideravelmente (LOCKLESS et al., 1999). Após esse método, Dekker e colaboradores propuseram um outro também baseado no conceito de "perturbação", porém com o cálculo da 
probabilidade das covariâncias, onde é medido o efeito de uma determinada "perturbação" sobre a distribuição em geral de um outro local, fornecendo assim uma medida mais diretamente relacionada à covariação estatística, que assim aumenta a probabilidade de encontrar regiões de contato, quando comparados com o algoritmo original do SCA (DEKKER et al., 2004).

Ao medir correlação posicional específica entre pares de resíduos, é possível definir uma rede na qual a existência de uma ligação entre dois resíduos implica que quando um dos aminoácidos da rede estiver em uma determinada posição o outro tende a estar fixo em outra posição, formando assim uma comunidade de resíduos. Uma comunidade pode ser definida como um conjunto de nós que mostram fortes ligações entre os mesmos, mas não para o resto da rede (BLEICHER; LEMKE; GARRATT, 2011).

Este tópico tem recebido atenção considerável por diferentes grupos desde o início de 2000 (FLAKE et al., 2002; NEWMAN; GIRVAN, 2004; RADICCHI et al., 2004), e agora é aplicado a uma grande variedade de problemas das ciências da vida, especialmente em biologia molecular. Uma análise de correlação de resíduos, pertencentes à família da superóxido dismutases de ferro/manganês, mostrou que tal fenômeno pode surgir também da especialização de certas características na mesma família de proteínas. Grupos de resíduos correlacionados podem estar associados à presença destas características, no caso, preferência por um dado metal e estado oligomérico (BACHEGA et al., 2009). Esta observação levou ao desenvolvimento de um método que objetiva identificar grupos de correlações específicas, denominado Decomposição de Redes de Correlações de Amino Ácidos (DRCN - do inglês "Decomposition of Residues Correlation Networks") (BLEICHER; LEMKE; GARRATT, 2011).

DRCN é um método que explora e quantifica correlações específicas utilizando um alinhamento de múltiplas sequencias (do inglês "Multiple Sequence Alignment", MSA). A partir desse são gerados comunidades de resíduos correlacionados ou anti-correlacionados, e com isso temos as redes de correlação de aminoácidos. As redes construídas podem ser analisadas por detecção de comunidades, a fim de encontrar grupos de aminoácidos específicos que possam interagir entre si. Estes resultados podem fornecer fatores determinantes para as propriedades de uma dada família de proteínas, e a análise mutacional desses a partir desses dados seria muito útil para se caracterizar uma proteína cuja função é completamente desconhecida (BLEICHER; LEMKE; GARRATT, 2011).

Esse método já se mostrou muito eficiente no entendimento das funções de várias proteínas, um exemplo é a proteína Her2p que é uma subunidade do complexo mitocondrial 
GatFAB amidotransferase. A análise de Her2p produzida pelo DRCN identificou oito conjuntos distintos de resíduos que coevoluiram na família. Mutagênese aleatória realizada por uma Taq DNA polimerase com baixa atividade revisora produziu mutantes em alguns resíduos presentes nesses conjuntos de aminoácidos que coevoluiram. Essas mutações causaram grandes perturbações nas funções de Her2p, indicando que os conjuntos de redes de Her2p são muito importantes para a atividade da proteína (FERREIRA-JÚNIOR; BLEICHER; BARROS, 2013).

Coq10p é uma proteína mitocondrial requerida para a função da CoQ6 na respiração. Em trabalhos anteriores, mostrou-se que Coq10p pode se ligar diretamente à CoQ6, mas não existia nenhum estudo estrutural que determinasse os resíduos importantes para essa ligação. Através da análise DRCN foram gerados quatros mutantes pontuais em Coq10p (K50E, L96S, $E 105 \mathrm{~K}$ e $\mathrm{K} 162 \mathrm{D}$ ) e todas as mutações realizadas causaram comprometimento na função da proteína e, em conjunto com modelagem molecular, indicaram que esses resíduos estão dentro de um provável túnel hidrofóbico. Isso sugeriu que os resíduos do túnel podem ser necessários para a ligação de CoQ6 (BUSSO et al., 2010).

Coq7p é uma enzima monooxigenase com centro di-férrico que participa da biossíntese da CoQ6 de levedura. A análise de DRCN dessa enzima indicou o resíduo S114 como membro de uma comunidade de aminoácidos. A mutação nesse resíduo (S114E) produziu uma diminuição de 7 vezes na produção de CoQ6 celular. Neste trabalho mostrou-se também que $S 114$ é um resíduo fosforilado, que é atraído pelo resíduo $R 57$, e essa fosforilação é responsável por diminuir a produção de CoQ6, sendo essa uma regulação negativa da via (FERREIRA-JÚNIOR et al., 2015).

Para todos os trabalhos citados acima esse método se mostrou muito robusto na identificação de resíduos para mutagênese e inferência da função das proteínas. Assim, a busca por mutantes utilizando esse método se mostra muito eficiente e poderá ser aplicada para identificar resíduos determinantes da função Rtg2p na longevidade. 


\section{OBJETIVOS}

\subsection{Objetivo geral}

Identificar os determinantes estruturais de Rtg2p envolvidos na sinalização retrógrada e no envelhecimento de $S$. cerevisiae.

\subsection{Objetivos específicos}

I. Identificar por Decomposition of residue correlation networks (DRCN) grupos de resíduos correlacionados e conservados a partir do MSA da Família PF02541 (Família de Rtg2p);

II. Construir mutantes por mutagênese sítio-dirigida baseados na análise de correlação;

III. Verificar os efeitos desses determinantes mutados na sinalização retrógrada e no envelhecimento replicativo; 


\section{MÉTODOS}

\subsection{Linhagens e meios de cultura}

Utilizou-se a linhagem PSY142 $\left(\rho^{+}\right.$MATa leu2 lys2 ura3::CIT2-LacZ) de $S$. cerevisiae, que apresenta resposta retrógrada robusta e gene repórter para quantificar a transcrição de CIT2. Derivados desta linhagem foram obtidos empregando-se técnicas clássicas de manipulação genética em levedura, como rompimento gênico por integração de DNA no genoma e substituição gênica (RADFORD, 1991; SEKITO; THORNTON; BUTOW, 2000; SHERMAN, 2002). Para a propagação dos plasmídeos utilizou-se a bactéria Escherichia coli DH5a.

Os meios de cultura empregados para manipulação de $S$. cerevisiae foram os meios ricos YPD (extrato de levedura 1\%, peptona 2\% e glicose 2\%) e YPG (extrato de levedura $1 \%$, peptona $2 \%$ e glicerol $2 \%$ ), e o meios mínimos YNBD (base nitrogenada de levedura 0,17\%; glicose 2\%; $\left.\left(\mathrm{NH}_{4}\right)_{2} \mathrm{SO}_{4} 0,5 \%\right)$, ou YNBD+, contendo glutamato na concentração final de $0,02 \%$ (para repressão da resposta retrógrada). Para manipulação em E. coli foi utilizado o meio LBampicilina (Triptona 1\%, Extrato de Levedura 0,5\%, $\mathrm{NaCl} 0,5 \%$, Ampicilina $100 \mu \mathrm{g} / \mathrm{mL})$. Para os meios sólidos adicionou-se no preparo ágar bacteriológico (2\%).

\subsection{Manipulação de DNA e técnicas gerais de biologia molecular}

Toda manipulação de DNA com enzimas de restrição, ligação de DNA, clonagem, eletroforese de DNA, isolamento de DNA e outras técnicas empregadas de biologia molecular foram feitas segundo descrito em manuais de referência (SAMBROOK; FRITSCH; MANIATIS, 1989), ou seguindo as recomendações dos fabricantes dos reagentes. A purificação de DNA separado em gel de agarose foi realizada com o kit Qiaquick (Qiagen), bem como a purificação de produtos de PCR. Realizou-se a transformação bacteriana na presença de cloreto de cálcio, conforme procedimento já descrito (HANAHAN, 1983), e transformação de levedura na presença de acetato de lítio (GIETZ, 2014).

Fez-se uso da Platinum ${ }^{\circledR}$ Taq DNA Polymerase High Fidelity (Life Technologies, USA) e da Phusion ${ }^{\circledR}$ High-Fidelity DNA Polymerase (New England BioLabs) para amplificações de DNA, seguindo as instruções fornecidas pela empresa, e mantendo as temperaturas de anelamento para cada um dos oligonucleotídeos iniciadores. Os nomes dos 
oligonucleotídeos desenhados e utilizados nesse estudo são apresentados na Tabela 1, assim como sua sequência e temperatura de anelamento (Ta) utilizada.

Tabela 1 - Oligonucleotídeos utilizados na construção de mutantes pontuais de RTG2.

\begin{tabular}{|c|c|c|}
\hline Nome & Sequência $\left(5^{\prime} \rightarrow 3^{\prime}\right)$ & $\begin{array}{r}\mathbf{T a} \\
\left({ }^{\circ} \mathbf{C}\right)\end{array}$ \\
\hline $\operatorname{Rtg} 2-597$ & GCG GGT GAA CAA GTC CTA AA & 55 \\
\hline Rtg2-2217 & TCA CTA GAC GAC TAC CCA ATC A & 55 \\
\hline rtg2-URF13- & CTT TAC TAA GGA TTG TTT TGA ACG AAA AGT GTA & \\
\hline KanMX-F & GGC GTG CCA CAA AAC AGC TAT GAC CAT GAT TAC & 55 \\
\hline rtg2-URF13- & AAG GAT TTC GTA TTT ATT GTT CAA GTA TTT AAA & \\
\hline KanMX-R & GAC TAG ATG TCT AAA ACG ACG GCC AGT GAA TTC & 55 \\
\hline KanB & CTG CAG CGA GGA GCC GTA AT & 56 \\
\hline $\mathrm{KanC}$ & TGA TTT TGA TGA CGA GCG TAA T & 49 \\
\hline Rtg2-F & TCA GCT AAG CTT GAA AGG AAG AAA TCA TCA AAG & 56 \\
\hline Rtg2-R & CTG ACT GGA TCC CTA CTT ATG TGA ACA TG & 56 \\
\hline L56G-F & GTT GGT CTT TCT GGA TAC GAA GTT CAA & 55 \\
\hline L56G-R & TTG AAC TTC GTA TCC AGA AAG ACC AAC & 55 \\
\hline E106H-F & GTA ATT GCA ACA CAT GCC ACG CGA GAT & 55 \\
\hline E106H-R & ATC TCG CGT GGC ATG TGT TGC AAT TAC & 55 \\
\hline E106A-F & GTA ATT GCA ACA GCA GCC ACG CGA GAT & 55 \\
\hline E106A-R & ATC TCG CGT GGC TGC TGT TGC AAT TAC & 55 \\
\hline R109E-F & ACA GAA GCC ACG GAA GAT GCT ATT AAC & 55 \\
\hline R109E-R & GTT AAT AGC ATC TTC CGT GGC TTC TGT & 55 \\
\hline N113A-F & CGA GAT GCT ATT GCC GCG GAT GAA TTT G & 55 \\
\hline N113A-R & CAA ATT CAT CCG CGG CAA TAG CAT CTC G & 55 \\
\hline E137A-F & GGC CAG GAA GAT GCA ACT AGG GTC GGC & 55 \\
\hline E137A-R & GCC GAC CCT AGT TGC ATC TTC CTG GCC & 55 \\
\hline T138A-F & GGT GGT AGT ACT GAG TTA TCA TGG GTA & 55 \\
\hline T138A-R & GGT GGT AGT ACT GAG TTA TCA TGG GTA & 55 \\
\hline D158A-F & GGT CTA TAT CTA GCT GTG GCA GGT GGT & 55 \\
\hline D158A-R & ACC ACC TGC CAC AGC TAG ATA TAG ACC & 55 \\
\hline A160G-F & TAT CTA GAT GTG GGA GGT GGT AGT ACT & 55 \\
\hline
\end{tabular}




\begin{tabular}{lll}
\hline A160G-R & AGT ACT ACC ACC TCC CAC ATC TAG ATA & 55 \\
G161A-F & CTA GAT GTG GCA GCT GGT AGT ACT CAG & 55 \\
G161A-R & CTG AGT ACT ACC AGC TGC CAC ATC TAG & 55 \\
S163A-F & GTG GCA GGT GGT GCT ACT CAG TTA TCA & 55 \\
S163A-R & TGA TAA CTG AGT AGC ACC ACC TGC CAC & 55 \\
Q165E-F & GGT GGT AGT ACT GAG TTA TCA TGG GTA & 55 \\
Q165E-R & TAC CCA TGA TAA CTC AGT ACT ACC ACC & 55 \\
Q165A-F & GGT GGT AGT ACT GCG TTA TCA TGG GTA & 55 \\
Q165A-R & TAC CCA TGA TAA CGC AGT ACT ACC ACC & 55 \\
\hline
\end{tabular}

\subsection{Construção do cassete rtg2::URF13-KanMX}

Rompeu-se o gene RTG2 a fim de realizar substituição gênica em seu locus. Dessa forma, as linhagens mutantes e a selvagem serão diferentes somente na posição da mutação pontual no genoma.

Para isto construiu-se um cassete de rompimento contendo URF13 e KanMX no vetor YIplac128 (GIETZ, R. DANIEL; SUGINO, 1988). Digeriu-se o vetor YIpTW (GLAB e al., 1993) com a enzima de restrição HindIII para liberar o fragmento de 2,6 kb contendo o gene T-urf13 que foi clonado no plasmídeo YIplac128. O gene KanMX do plasmídeo pYM-N18 (JANKE et al., 2004) foi retirado com as enzimas BamHI e SacI, e o fragmento de 1474pb foi clonado no vetor YIplac128-T-urf13. O vetor final pURF13-KanMX possui o cassete de rompimento composto pela região codificadora do gene T-urf13 de Zea mays flanqueada pelo promotor e terminador da fosfoglicerato quinase de levedura (PGK1) (GLAB; PETIT; SLONIMSKI, 1993), clonada adjacente ao gene que confere resistência à geneticina (KanMX) sobre controle do promotor e terminador TEF. Amplificou-se o cassete rtg2::URF13-KanMX com os primers rtg2-URF13-KanMX-F e rtg2-URF13-KanMX-R (Tabela 1). Esse produto de PCR possui 45 nucleotídeos flanqueadores das sequências promotora e terminadora de $R T G 2$, que permitem a recombinação homóloga no locus de RTG2.

\subsection{Rompimento gênico de $R T G 2$}

Utilizou-se o produto de PCR do cassete rtg2::URF13-KanMX para romper o gene RTG2 na cepa PSY142, transformando-se as células na presença de acetato de lítio, conforme 
descrito por Gietz e Woods (2014). A partir do estoque a $-80{ }^{\circ} \mathrm{C}$ cresceram-se células de $S$. cerevisiae PSY142 em meio YPD ágar e incubou-se em estufa a $30{ }^{\circ} \mathrm{C}$. Após 48 horas, inocularam-se as células em $5 \mathrm{~mL}$ de YPD líquido que foram crescidas a $30{ }^{\circ} \mathrm{C}, 200 \mathrm{rpm}$, por 16 horas. Em seguida, inoculou-se, em $50 \mathrm{~mL}$ de YPD, uma densidade de células de $5 \times 10^{6}$ células $/ \mathrm{mL}\left(\mathrm{A}_{600}=0,166\right)$ e incubou-se a $30{ }^{\circ} \mathrm{C}$, em agitador orbital a $200 \mathrm{rpm}$, até atingir a densidade $2 \times 10^{7}$ células $/ \mathrm{mL}\left(\mathrm{A}_{600}=0,666\right)$. Em seguida, centrifugaram-se as células à temperatura ambiente por $10 \mathrm{~min}$ a $2.500 \mathrm{rpm}$. Lavou-se o sedimento celular uma vez com 25 $\mathrm{mL}$ de $\mathrm{H}_{2} \mathrm{O}$ estéril e centrifugou-se nas mesmas condições anteriores. Descartou-se o sobrenadante e ressuspenderam-se as células em $1 \mathrm{~mL}$ de acetato de lítio $100 \mathrm{mM}$, transferindo-as para um tubo de microcentrífuga de $1.5 \mathrm{~mL}$, centrifugando-as por $5 \mathrm{~s}$ a 12.000 rpm. Removeu-se o acetato de lítio com micropipeta e ressuspendeu-se o sedimento em 400 $\mu \mathrm{L}$ de acetato de lítio $100 \mathrm{mM}$, atingindo o volume final de $500 \mu \mathrm{L}$, e separou-se em 10 alíquotas de $50 \mu \mathrm{L}$ cada. Os tubos dessas alíquotas foram centrifugados nas mesmas condições citada acima e removeu-se o acetato de lítio com micropipeta. Adicionaram-se às células os reagentes da transformação, cuidadosamente, na seguinte ordem: $240 \mu \mathrm{L}$ de polietilenoglicol $335050 \%, 36 \mu \mathrm{L}$ de acetato de lítio $1 \mathrm{M}, 25 \mu \mathrm{L}$ de DNA carregador fita simples $(2 \mathrm{mg} / \mathrm{mL}$ ), $50 \mu \mathrm{L}$ de DNA (obtido por digestão plasmidial). Cada microtubo foi agitado vigorosamente até se obter uma mistura homogênea, que foi incubada a $30{ }^{\circ} \mathrm{C}$ por 30 minutos. Em seguida, submeteram-se os tubos a um choque térmico a $42{ }^{\circ} \mathrm{C}$ por 20 minutos e posteriormente centrifugou-se por $15 \mathrm{~s}$ a $8.000 \mathrm{rpm}$. Removeu-se a mistura da transformação com a micropipeta, os sedimentos celulares foram ressuspensos em $200 \mu \mathrm{L}$ de $\mathrm{H}_{2} \mathrm{O}$ estéril e então plaqueados em meio YPD ágar com geneticina (G418, $200 \mu \mathrm{g} / \mathrm{mL})$.

Para o controle negativo as células foram transformadas sem o produto de digestão plasmidial e plaqueadas em meio com geneticina.

\subsection{Confirmação do locus de integração do cassete rtg2::URF13-KanMX}

Para confirmar o locus de integração do cassete rtg2::URF13-KanMX, realizou-se a extração de DNA genômico de seis transformantes que cresceram nas placas contendo geneticina. Inocularam-se as células em $5 \mathrm{~mL}$ de meio YPD a $30{ }^{\circ} \mathrm{C}$ por $16 \mathrm{~h}$. No dia seguinte, transferiu-se $1,5 \mathrm{~mL}$ de cultura para um tubo de microcentrifuga e centrifugou-se por 30s a $13.000 \mathrm{rpm}$, descartando-se o sobrenadante e adicionando-se $300 \mu \mathrm{L}$ de tampão de lise (2\% Triton $\mathrm{X}-100,1 \% \mathrm{SDS}, 100 \mathrm{mM}$ de $\mathrm{NaCl}$ e $20 \mathrm{mM}$ Tris-HCl pH8.0), um volume equivalente a $100 \mu \mathrm{g}$ de microesferas de vidro $(400-600 \mu \mathrm{m})$ e $200 \mu \mathrm{L}$ de 
fenol/clorofórmio/álcool isoamílico (25:24:1). Realizou-se a lise com o uso de um agitador de tubos tipo Vortex à temperatura ambiente por 5 min e centrifugou-se por 5 min a $13.000 \mathrm{rpm}$. Em seguida recuperou-se a fase aquosa e adicionou-se $1 \mathrm{~mL}$ de etanol $100 \%$ gelado; misturou-se e centrifugou-se por $2 \mathrm{~min}$ a $13.000 \mathrm{rpm}$. Descartou-se o sobrenadante e adicionou-se $400 \mu \mathrm{L}$ de TE (10 mM Tris $\mathrm{HCl}$ pH 8,0, 1 mM EDTA pH8.0) e $3 \mu \mathrm{L}$ de RNAse $(10 \mathrm{mg} / \mathrm{mL})$ e incubou-se a $37{ }^{\circ} \mathrm{C}$ por 30 minutos. Passado esse tempo, adicionou-se $5,4 \mu \mathrm{L}$ de $\mathrm{NH}_{4} \mathrm{OAc}$ 7,5 M, agitando-se vigorosamente por 10 segundos e adicionando-se $1 \mathrm{~mL}$ de Etanol $100 \%$ a $-20{ }^{\circ} \mathrm{C}$ para precipitar o DNA. Posteriormente, centrifugou-se por 2 min a $4{ }^{\circ} \mathrm{C}$ por $13.000 \mathrm{rpm}$ e descartou-se o sobrenadante. Adicionou-se $1 \mathrm{~mL}$ de etanol $70 \%$ a $-20{ }^{\circ} \mathrm{C}$ e centrifugou-se nas mesmas condições citada acima e descartou-se o sobrenadante. Secou-se o sedimento ao ar por 20 min e ressuspendeu-se o DNA obtido em $70 \mu \mathrm{L}$ de TE. A partir desse DNA realizaram-se reações de PCR com os pares de oligonucleotídeos rtg2-597up-F/KanB e KanC/rtg2-2217down-F (Tabela 1), para mostrar que o gene $R T G 2$ havia sido rompido pelo cassete e que integrou no locus correto.

Para verificar se o cassete $\operatorname{rtg} 2:$ URF13-KanMX integrou-se no genoma, os seis transformantes foram crescidos na presença de Metomil (6 mM), pois o gene T-urf13 confere sensitividade ao carbamato metomil, e na ausência ou presença de glutamato $(0,02 \%)$ em placas YNBD, pois mutantes $\operatorname{rtg} 2 \Delta$ são auxotróficos para glutamato, quando crescidos em meio mínimo na ausência deste aminoácido.

\subsection{Construção dos mutantes por mutagênese sítio-dirigida}

Para produzir os mutantes de $R T G 2$, realizou-se mutagênese sítio-dirigida de acordo com Heckman (2007), por sobreposição de produtos de PCR (overlap extension PCR) (Figura 5). Realizaram-se duas reações de PCR independentes com os primers Rtg2-F(1) e 2M; $1 \mathrm{M}$ e Rtg2-R(2), sendo que cada produto de PCR possuía 20 pares de bases de sobreposição. Os primers 1 e 2 estão localizados a -1000 pb e +2042 pb do gene $R T G 2$, respectivamente, os primers $1 \mathrm{M}$ e $2 \mathrm{M}$ foram desenhados a partir da identificação dos resíduos candidatos obtidos através da DRCN (Tabela 1) (HECKMAN; PEASE, 2007). 

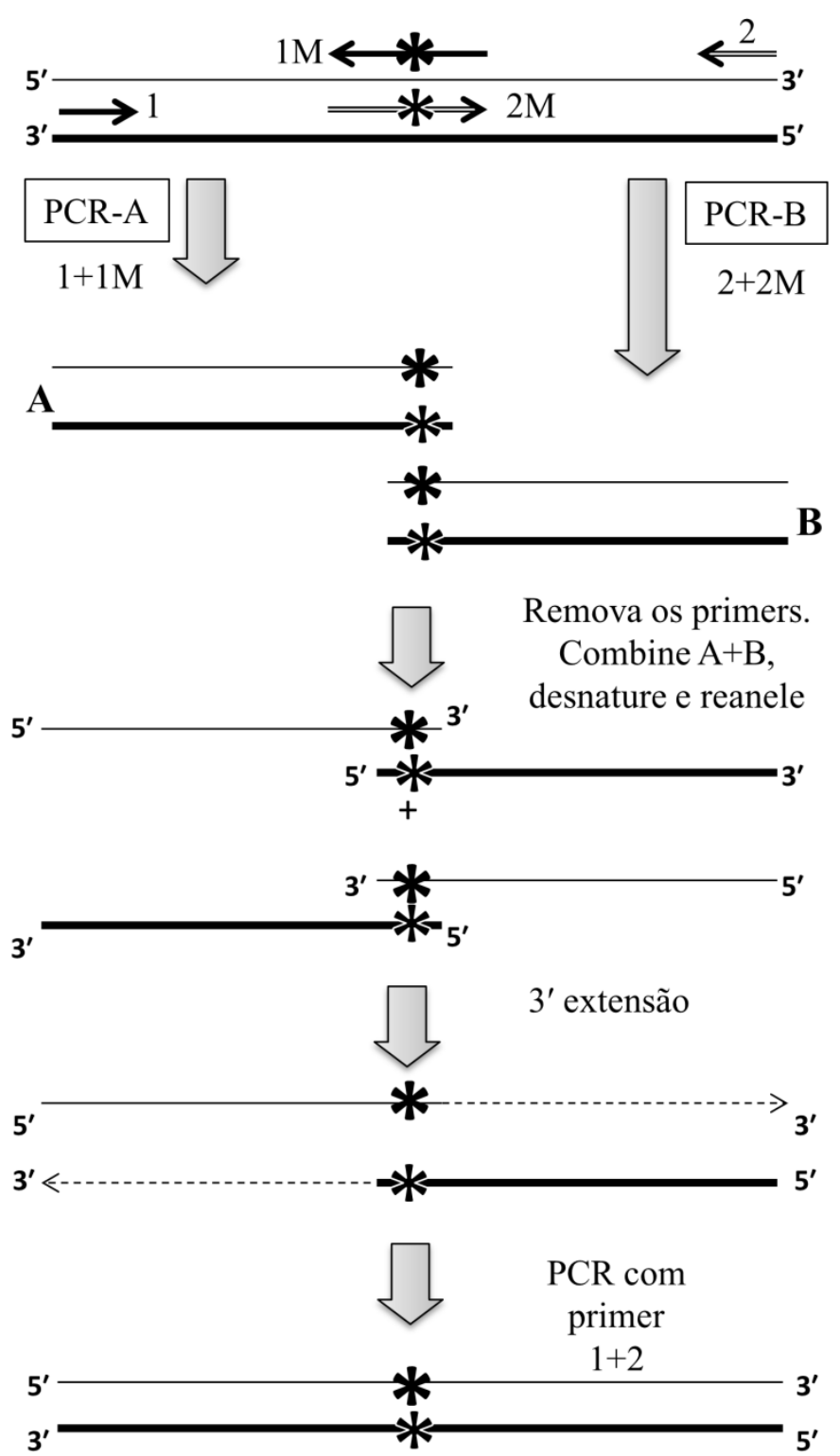

Figura 5 - Esquema da Mutagênese sítio dirigida por sobreposição de produtos de PCR (ver texto para descrição detalhada).

A partir dessas PCRs geraram-se dois produtos para cada mutação (PCR-A e PCR-B), que foram combinados, desnaturados e pareados pelos $20 \mathrm{pb}$ das extremidades, e adicionou-se a enzima Taq DNA polimerase a fim de extender as extremidades 3' na ausência de primers, durante 10 ciclos, em uma reação de PCR. Em seguida a esses ciclos adicionaram-se os primers das extremidades (primers Rtg2-F e Rtg2-R), para obter-se o produto de PCR com o comprimento total do gene $R T G 2$, contendo a mutação inserida. 


\subsection{Clonagem dos mutantes no vetor pGEM-3Zf(+)}

Todos os mutantes continham nas extremidades $3^{\prime}$ sítios para a enzima de restrição BamHI e na extremidade 5' sítio para a enzima HindIII, que foram utilizados para a inserção no vetor pGEM-3Zf(+). Os mutantes clonados foram transformados em bactérias competentes DH5 $\alpha$, de acordo com Hanahan (1983). Para isto mantiveram-se as bactérias competentes (retiradas do freezer a $-80{ }^{\circ} \mathrm{C}$ ) no gelo durante, aproximadamente, 15 minutos. Feito isso, adicionou-se $5 \mu \mathrm{L}$ da ligação a $50 \mu \mathrm{L}$ de bactérias e incubou-se no gelo durante 30 min sendo, em seguida, submetidos a choque térmico por $1 \min 30 \mathrm{~s}$ a $42{ }^{\circ} \mathrm{C}$, seguido de 5 min em gelo. Adicionou-se $380 \mu \mathrm{L}$ de meio LB ao tubo, seguindo-se um período de incubação de $1 \mathrm{~h}$ a 37 ${ }^{\circ} \mathrm{C}$, sob agitação de $200 \mathrm{rpm}$ e, ao final, espalhou-se em placas de meio LB contendo ampicilina $(100 \mu \mathrm{g} / \mathrm{mL})$ e incubou-se por um período de 16 horas em estufa a $37{ }^{\circ} \mathrm{C}$. Após esse período, colônias foram inoculadas em meio LB contendo ampicilina e realizada uma mini preparação de DNA plasmidial com o Kit Wizard® Plus SV Minipreps DNA Purification de acordo com as recomendações do fabricante.

\subsection{Sequenciamento de DNA}

Realizou-se o sequenciamento de DNA, a partir dos plasmídeos contendo o gene com a mutação, no Centro de Pesquisas sobre o Genoma Humano e células-tronco (CEGHCEL), utilizando o sequenciador ABI 3730 DNA Analyser, um sistema de análise de DNA de 48 capilares (Life Technologies - Applied Biosystems) e as reações de sequenciamento utilizando o BigDye ${ }^{\circledR}$ Terminator v3.1 Cycle Sequencing Kit (código 4337456). As sequências foram analisadas no software BioEdit 7.2.5 (Hall et al 2007).

\subsection{Integração dos mutantes no locus de $R T G 2$}

Seguido o sequenciamento, fez-se a digestão dos plasmídeos com BamHI e HindIII para liberar o fragmento com o gene mutado; a partir do produto total da digestão realizou-se a transformação na cepa PSY142 $\operatorname{rtg} 2 \Delta$ (rtg2::URF13-KanMX), na presença de acetato de lítio como no tópico 3.4 citado acima.

Para confirmar a integração dos genes com a mutação no locus de $R T G 2$ foram selecionados alguns clones na presença de metomil $(6 \mathrm{mM})$. Se o mutante de RTG2 foi reintegrado no genoma os clones irão crescer na presença de metomil. Também extraiu-se o 
DNA dos clones obtidos e realizou-se a confirmação de locus de integração com os pares de primers rtg2-597up-F/G337-R (Tabela 1).

\subsection{Ensaio de auxotrofia para glutamato}

Para a realização do ensaio de auxotrofia para glutamato, cresceram-se as células até $\mathrm{A}_{600}=1$ e submeteram-se a 4 diluições seriadas $\left(10^{-1}, 10^{-2}, 10^{-3}\right.$ e $\left.10^{-4}\right)$. Depositou-se $3 \mu \mathrm{L}$ de cada diluição sobre placas YNBD contendo glutamato $(0,02 \%)$ e placas sem glutamato. Para observar o crescimento diferencial dos mutantes incubaram-se as placas a $30^{\circ} \mathrm{C}$ por 3 dias e fotografou-se o crescimento após esse período.

\subsection{Curva de crescimento}

As células foram inoculadas em microplacas $\operatorname{Costar}^{\circledR}$ de poliestireno de 96 poços (Fundo U) até a $\mathrm{A}_{600}=0,1$ em meio YNBD e $\mathrm{YNBD}^{+}$, e incubou-se no leitor de absorbância INFINITY PRO 200 (Sunrise Tecan), com agitação constante de $320 \mathrm{rpm}$ a $30{ }^{\circ} \mathrm{C}$, com leituras da $\mathrm{A}_{600}$ a cada hora por um período total de $24 \mathrm{~h}$.

\subsection{Ensaio de $\beta$-galactosidase}

Todas as linhagens mutantes possuem, como gene repórter da sinalização retrógrada, CIT2-LacZ integrado no genoma. Procedeu-se o ensaio conforme descrito por Rose e colaboradores (1991)(RADFORD, 1991). Cresceu-se uma pré-cultura dos transformantes a 30 ${ }^{\circ} \mathrm{C}$ por $16 \mathrm{~h}$, em meio líquido YNBD. Em seguida, cresceram-se as células em inóculos com $\mathrm{A}_{600}($ inicial $)=0,01$ agitando-se a $200 \mathrm{rpm}$, a $30^{\circ} \mathrm{C}$, até atingir $\mathrm{A}_{600}=0,6($ GUARAGNELLA; BUTOW, 2003). Coletou-se um volume equivalente a $2 \times 10^{8}$ células por centrifugação e lisou-se em agitador tipo vórtex na presença de tampão de lise $(100 \mathrm{mM}$ Tris- $\mathrm{HCl} \mathrm{pH} 8,1$ $\mathrm{mM}$ Ditiotreitol, 20\% Glicerol) e microesferas de vidro por $2 \mathrm{~min}$, alternando os tubos 8 vezes por 15 segundos, sempre mantendo-se as amostras no gelo a cada ciclo. Após a lise, transferiu-se o extrato celular para um tubo de microcentrifuga limpo e centrifugou-se a $12.000 \mathrm{rpm}$ por $5 \mathrm{~min}$. Foram retiradas três alíquotas do sobrenadante, com o auxilio de uma pipeta de $1000 \mu \mathrm{L}$, para ensaio de $\beta$-galactosidase na presença de ONPG $4 \mathrm{mg} / \mathrm{mL}$ (onitrofenil- $D$-galactosídeo). A atividade foi expressa em nmols/min/mg proteína e a 
concentração proteica determinada pelo método de Bradford (Bio-Rad Protein Assay).Todo o ensaio foi realizado em triplica.

\subsection{Ensaio de Longevidade Replicativa}

Procedeu-se o ensaio de longevidade replicativa de acordo com Park e colaboradores (2012) (PARK; MCVEY; GUARENTE, 2002). A partir do estoque a $-80{ }^{\circ} \mathrm{C}$, cresceram-se células em meio YPD ágar, que foram mantidas em estufa a $30{ }^{\circ} \mathrm{C}$. Após 48 horas as células foram semeadas novamente em YPD e incubadas por $24 \mathrm{~h}$, para a obtenção de colônias isoladas; semearam-se novamente algumas colônias em uma placa YPG, a fim de remover quaisquer células petites da população. A partir da placa YPG, foi escolhida uma colônia e crescida novamente em YPD a $30{ }^{\circ} \mathrm{C}$ por um dia. Com um palito de dente estéril, transferiuse uma pequena quantidade de células que foi riscada em uma placa YPD (Figura 6, oval escuro). Usando uma agulha de vidro ligada a um micromanipulador SporePLAY (Singer Instruments), selecionou-se 50 células, separadas a cerca de $50 \mu \mathrm{m}$ entre elas, para fornecer espaço suficiente para separar as mães das filhas. Após alinhar as células fez-se o isolamento da segunda filha gerada de cada mãe (célula-mãe fundadora) para dar inicio ao ensaio. Incubaram-se as células a $30{ }^{\circ} \mathrm{C}$ durante $90 \mathrm{~min}$, e, após esse período, realizou-se a separação da célula-mãe da célula-filha, utilizando-se o micromanipulador, repetindo esse processo até cessar a produção de novas células-filhas e registrando cada brotamento, para ao final obter-se o número de vezes que cada célula-mãe gerou uma nova célula-filha. Durante a noite incubou-se as células a $4{ }^{\circ} \mathrm{C}$. Esse processo repetiu-se ao longo do experimento até que todas as células não produzissem mais células-filhas. A significância estatística foi medida pelo teste não-paramétrico Mann-Whitney Rank sum test. 


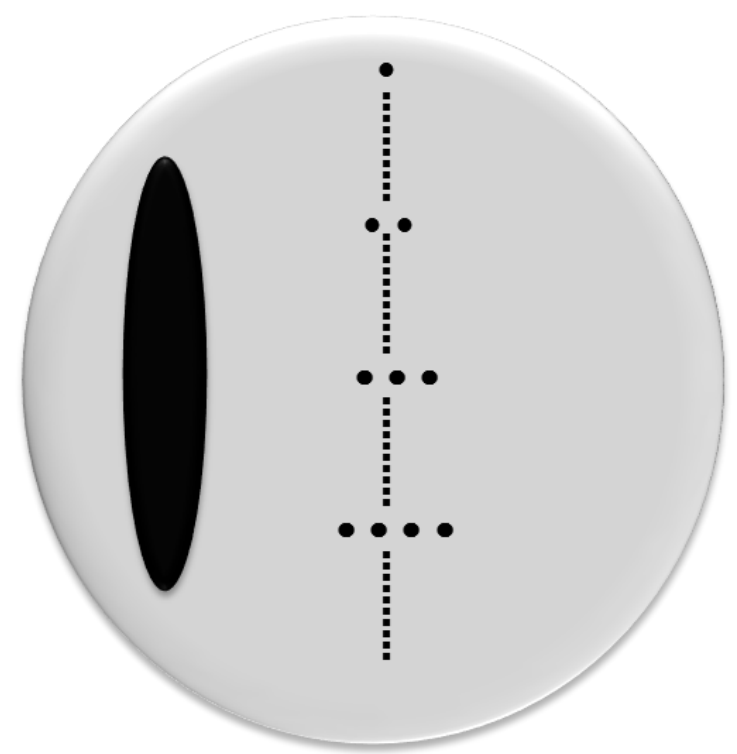

Figura 6 - Esquema de uma placa YPD para ensaio de longevidade replicativa. As células são inicialmente riscadas na placa (oval esquerdo). Células-mãe (pontos pretos menores) são isoladas no meio da placa em grupos de 10, e as suas posições são marcadas por furos no ágar (pontos pretos maiores). Após a incubação, as filhas são separadas das mães e movidas para a região direita da placa.

\subsection{Decomposição de Redes de Correlação de Aminoácidos (DRCN)}

Foram utilizadas sequências da Família PF02541 (Família de Rtg2p), alinhadas, obtidas diretamente do banco de dados Pfam (http://pfam.xfam.org/). Analisou-se o alinhamento de múltiplas sequências através do software PFSTATS, desenvolvido por Bleicher e colaboradores (2011). O PFSTATS realizou quatro etapas de processamento/análise.

\subsubsection{Filtragem}

O alinhamento obtido no Pfam foi filtrado através do software PFSTATS, para eliminação de sequências proteicas muito similares ou sequências menores que o padrão do alinhamento. Para isto realizaram-se três cortes:

Cobertura mínima de alinhamento: comparou-se cada sequência com a de $\operatorname{Rtg} 2 p$ e removeram-se sequências com menos de $80 \%$ dos resíduos alinhados; com isso sequências fragmentadas foram eliminadas bem como sequências com tamanho superior ao da proteína de interesse.

Remoção de sequências com baixa identidade: com o alinhamento processado na etapa anterior, realizou-se outra filtragem onde se removeu as sequências com identidade inferior a $10 \%$ (quando comparados à sequência de Rtg2p) do alinhamento. 
Remoção de sequências similares: por último, comparou-se cada sequência com todas as outras, e eliminaram-se as sequências que eram $70 \%$ semelhantes entre si, ou seja, duas sequências muito parecidas eram comparadas e a de menor comprimento era eliminada.

\subsubsection{Perturbação estatística}

Após o alinhamento ser filtrado, realizou-se um experimento de perturbação estatística, no qual se fixa a distribuição de aminoácidos em um dado resíduo e observam-se as alterações de distribuição nas demais posições. Na figura 7 mostra-se esse experimento com uma proteína hipotética, destacando-se quatro posições $a, b, c$ e $d$. A perturbação estatística permite verificar se os resíduos nas posições $c$ e $d$ atuam cooperativamente (Figura 7A). No alinhamento as frequências dos aminoácidos em uma dada posição são indicadas (Figura 7B). Realizou-se a perturbação e gerou-se um subalinhamento, onde fixou-se histidina na posição $c$ e calculou-se a frequência dos outros aminoácidos nas demais posições e foi possível observar que a frequência da isoleucina na posição $d$ aumentou de $40 \%$ para $60 \%$ e a frequência de leucina diminuiu de $40 \%$ para $20 \%$, enquanto a frequência das posições $a$ e $b$ permanecem da mesma forma. Nas posições em que a frequência dos aminoácidos não alterase os resíduos não estão acoplados, já nas posições em que altera, há acoplamento/coevolução/correlação (Figura 7C). 
A

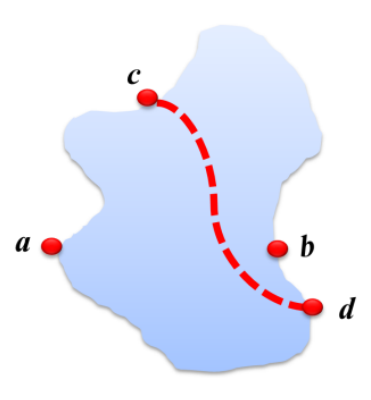

B

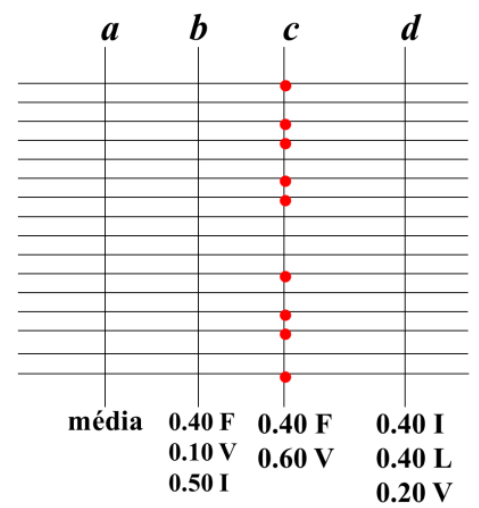

C

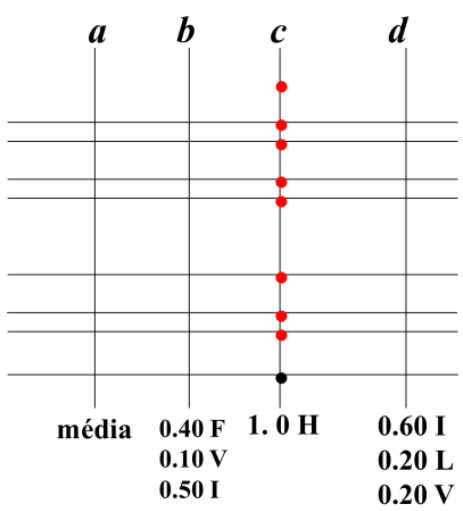

Figura 7 - Método de perturbação estatística para medir acoplamentos entre posições de alinhamento de proteínas. A: proteína hipotética contendo quatro posições $\boldsymbol{a}, \boldsymbol{b}, \boldsymbol{c}$ e $\boldsymbol{d}$ As posições $\boldsymbol{a}$ e $\boldsymbol{b}$ atuam independentemente um do outro; $\boldsymbol{c}$ e $\boldsymbol{d}$, cooperativamente. B: representação esquemática de um MSA de uma família de proteínas, com as frequências de seus aminoácidos indicadas nas quatro posições. Linhas horizontais representam sequências de proteínas individuais. As frequências dos aminoácidos no MSA estão indicadas. C: Subalinhamento resultante de um experimento de perturbação onde o sítio $c$ é fixado em histidina.

\subsubsection{Matrizes de autocorrelação e detecção de comunidades}

Após o experimento de perturbação estatística são geradas matrizes de autocorrelação, a partir do PFSTATS, com o score de correlação entre as posições de resíduos, onde representam-se somente os resíduos mais fortemente acoplados. Os resíduos obtidos na matriz de autocorrelação foram submetidos ao algoritmo de Newman (NEWMAN; GIRVAN, 2004), onde são geradas redes de contato e os componentes conectados na rede são denominados comunidades. As comunidades são subconjuntos de resíduos acoplados.

\subsubsection{Análise de Resíduos conservados}

Após a análise das comunidades é feita uma análise de conservação simples dos resíduos de aminoácidos, a partir do alinhamento da família PF02541, em comparação com a sequência de Rtg2p, e, diferente da perturbação estatística, essa análise calcula apenas a frequência de um dado aminoácido em uma dada posição. Selecionou-se somente os resíduos com conservação superior a $90 \%$. 


\subsection{Modelagem molecular de Rtg2p}

A proteína $\operatorname{Rtg} 2 p$ ainda não possui estrutura cristalográfica resolvida; então, a fim de facilitar a visualização dos resíduos correlacionados e conservados, realizou-se sua modelagem molecular em cinco servidores independentes, Robetta (KIM; CHIVIAN; BAKER, 2004), SWISS-MODEL (ARNOLD et al., 2006), Phyre2 (KELLEY; STERNBERG, 2009; KELLEY et al., 2015), ESyPred3D (LAMBERT et al., 2002) e I-TASSER (ZHANG, 2008). Os programas dos servidores ESyPred3D, SWISS-MODEL e Phyre2 realizam modelagem por homologia, ou seja, baseiam-se na estrutura tridimensional de proteínas homólogas; I-TASSER é um servidor que realiza modelagem por threading onde cada aminoácido da sequência a ser modelada é alinhado a uma estrutura molde e o Robetta realiza modelagem por métodos ab initio, assim constrói modelos baseados nas propriedades físicas dos aminoácidos partindo de uma estratégia que não se restringe a moldes pré-estabelecidos. Os modelos obtidos foram validados, inicialmente, por análise do Diagrama de Ramachandran; nele é possível visualizar todas as combinações possíveis de ângulos diédricos $\Psi$ (psi) versus $\Phi$ (phi) nos aminoácidos de um polipeptídio, que contribuem para a conformação da proteína, e com isso é possível verificar a qualidade das estruturas tridimensionais obtidas pelos servidores utilizados. Realizou-se uma segunda validação através do programa Verify3D (LÜTHY; BOWIE; EISENBERG, 1992), que avalia a compatibilidade entre a estrutura tridimensional de uma proteína e a sua própria sequência de aminoácidos, e estabelece um score total relacionado à qualidade do modelo, a partir desses dados foi determinado o melhor modelo. As figuras foram geradas pelo programa PyMol (DELANO, 2002). 


\section{RESULTADOS}

\subsection{Decomposição de Redes de Correlações de Aminoácidos (DRCN) de Rtg2p}

A proteína Rtg2p possui um domínio N-terminal similar ao de exopolifosfatases, muito importante para sua função (KOONIN, 1994). Já se sabe que mutantes neste domínio N-terminal são incapazes de transmitir os sinais mitocondriais da sinalização retrógrada (LIU et al., 2003). Por isso realizou-se uma análise bioinformática deste domínio com o software PFSTATS, utilizando-se o alinhamento da Família PF02541 (Família de Rtg2p) obtido no Pfam. Essa análise permitiu obter matrizes de autocorrelação que geraram três comunidades de resíduos fortemente acoplados (Tabelas 2, 3 e 4).

Tabela 2 - Matriz de autocorrelação da comunidade 1 da análise DRCN de Rtg2p.

\begin{tabular}{cccc}
\hline $\begin{array}{c}\text { Posição no } \\
\text { Alinhamento }\end{array}$ & $\begin{array}{c}\text { Frequência do } \\
\text { aminoácido } \\
(\boldsymbol{\%})\end{array}$ & $\begin{array}{c}\text { Frequência do } \\
\text { aminoácido fixando } \\
\text { E106 }(\%)\end{array}$ & $\begin{array}{c}\text { Frequência do } \\
\text { aminoácido fixando } \\
\text { P322 (\%) }\end{array}$ \\
\hline E106 & 20.8 & $\mathrm{X}$ & 83.9 \\
P322 & 20.5 & 82.5 & $\mathrm{X}$ \\
\hline
\end{tabular}

Tabela 3 - Matriz de autocorrelação da comunidade 2 da análise DRCN de Rtg2p.

\begin{tabular}{cccc}
\hline $\begin{array}{c}\text { Posição no } \\
\text { Alinhamento }\end{array}$ & $\begin{array}{c}\text { Frequência do } \\
\text { aminoácido } \\
(\boldsymbol{\%})\end{array}$ & $\begin{array}{c}\text { Frequência do } \\
\text { aminoácido fixando } \\
\mathbf{A 1 3 8}(\boldsymbol{\%})\end{array}$ & $\begin{array}{c}\text { Frequência do } \\
\text { aminoácido fixando } \\
\text { E165 }(\boldsymbol{\%})\end{array}$ \\
\hline A138 & 81.8 & $\mathrm{X}$ & 92.0 \\
E165 & 87.2 & 98.1 & $\mathrm{X}$ \\
\hline
\end{tabular}

Tabela 4 - Matriz de autocorrelação da comunidade 3 da análise DRCN de Rtg2p.

\begin{tabular}{cccc}
\hline $\begin{array}{c}\text { Posição no } \\
\text { Alinhamento }\end{array}$ & $\begin{array}{c}\text { Frequência do } \\
\text { aminoácido } \\
(\boldsymbol{\%})\end{array}$ & $\begin{array}{c}\text { Frequência do } \\
\text { aminoácido fixando } \\
\text { L192 (\%) }\end{array}$ & $\begin{array}{c}\text { Frequência do } \\
\text { aminoácido fixando } \\
\text { G333 (\%) }\end{array}$ \\
\hline L192 & 68.6 & $\mathrm{X}$ & 84.2 \\
G333 & 65.8 & 80.8 & $\mathrm{X}$ \\
\hline
\end{tabular}


Nas tabelas 2, 3 e 4 apresentam-se as 3 comunidades detectadas para a proteína Rtg2p. A coluna "Frequência do aminoácido" refere-se à frequência total do aminoácido no alinhamento completo, antes do experimento de perturbação estatística; as colunas seguintes referem-se à frequência de um aminoácido no subalinhamento, após a perturbação estatística. É possível observar que a matriz 1 apresentou os resíduos mais fortemente acoplados, pois fixando-se prolina na posição 322 do subalinhamento, a frequência de glutamato na posição 106 aumenta de 20,8\% para 83,9\% (Tabela 2), na matriz 2 fixando-se alanina na posição 138 a frequência de glutamato 165 aumenta de $81,8 \%$ para $92 \%$ e na matiz 3, fixando-se leucina na posição 192 a frequência de glicina na posição 333 aumenta de 68,6\% para 84,2\%. Esses resíduos acoplados são de aminoácidos que coevoluiram na estrutura da proteína, fortes candidatos à mutagênese sítio-dirigida.

Com o alinhamento obtido também realizou-se uma análise de conservação dos resíduos de aminoácidos. Nesta análise foram indicados somente resíduos com conservação superior a 90\% da família PF02541 (Tabela 5). Em particular, na posição 418 do alinhamento, em 99,8\% das sequências ocorre glicina, enquanto que Rtg2p possui alanina na mesma posição, indicando uma divergência da família. Pode-se destacar também os resíduos nas posições 204, 262 e 495 do alinhamento; em 100\% das sequências ocorre treonina, glutamato e glicina, respectivamente, indicando que esses resíduos são altamente conservados na família e também fortes candidatos à mutagênese sítio dirigida. 
Tabela 5 - Resíduos com conservação superior a 90\% na Família PF02541.

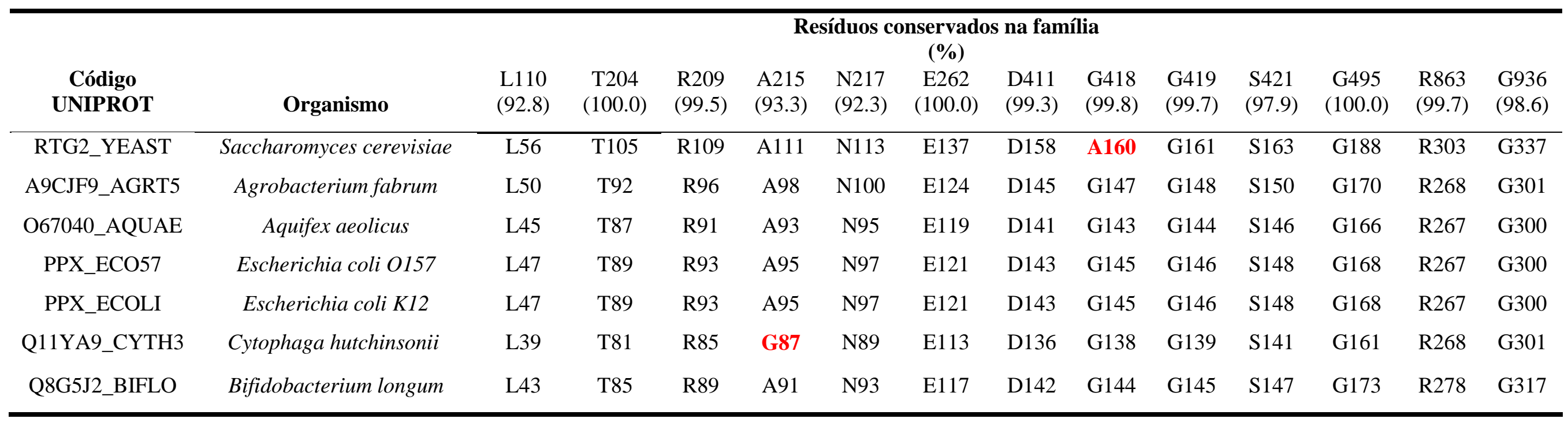




\subsection{Modelagem molecular de Rtg2p}

Após as análises de correlação e conservação dos aminoácidos, foi necessário obter um modelo estrutural de Rtg2p, para facilitar a localização dos resíduos e escolher os melhores para mutagênese. A proteína em estudo não possui estrutura cristalográfica determinada devido a grande dificuldade de sua purificação, já que se mostrou insolúvel quando expressa em bactéria (ZHANG et al., 2013). Por essa razão, a proteína Rtg2p foi modelada em cinco servidores independentes, Robetta, SWISS-MODEL, Phyre2, ESyPred3D e I-TASSER, e sua estrutura validada por duas métricas distintas, o Diagrama de Ramachandran (Tabela 6) que avalia as combinações possíveis de ângulos diédricos $\Psi$ (psi) versus $\Phi$ (phi) e o Software Verify $3 \mathrm{D}$, que compara a compatibilidade entre a estrutura tridimensional e a sequência de aminoácidos (Tabela 7).

Tabela 6 - Validação pelo Diagrama de Ramachandran dos modelos tridimensionais de Rtg2p obtidos em diferentes servidores.

\section{Diagrama de Ramachandram}

\begin{tabular}{cccc} 
Servidor & Região Favorável & $\begin{array}{c}\text { Região } \\
\text { Permitida }\end{array}$ & $\begin{array}{c}\text { Região } \\
\text { Aceitável }\end{array}$ \\
\hline Robetta & $90,2 \%$ & $6,9 \%$ & $1,5 \%$ \\
Swiss-Model & $86,2 \%$ & $11,4 \%$ & $1,2 \%$ \\
Phyre 2 & $86,3 \%$ & $12,0 \%$ & $0,7 \%$ \\
EsyPred3D & $84,7 \%$ & $11,8 \%$ & $2,6 \%$ \\
I-Tasser & $75,9 \%$ & $17,2 \%$ & $6,8 \%$ \\
\hline
\end{tabular}

Tabela 7 - Validação pelo Verify3D dos modelos tridimensionais de Rtg2p obtidos em diferentes servidores

\begin{tabular}{cc}
\hline Servidor & $\begin{array}{c}\text { Compatibilidade da } \\
\text { estrutura }\end{array}$ \\
\hline Robetta & $82,48 \%$ \\
Swiss-Model & $74,69 \%$ \\
Phyre 2 & $76,34 \%$ \\
I-Tasser & $71,09 \%$ \\
EsyPred3D & $56,27 \%$ \\
\hline
\end{tabular}

Com base nas métricas, o modelo obtido no servidor Robetta foi selecionado para utilização no trabalho (Figura 8), porque apresentou mais de $90 \%$ dos resíduos nas regiões 
favoráveis pelo Diagrama de Ramachandram e mais de $80 \%$ de coerência entre o modelo gerado e sua sequência de aminoácidos pelo Verify3D.

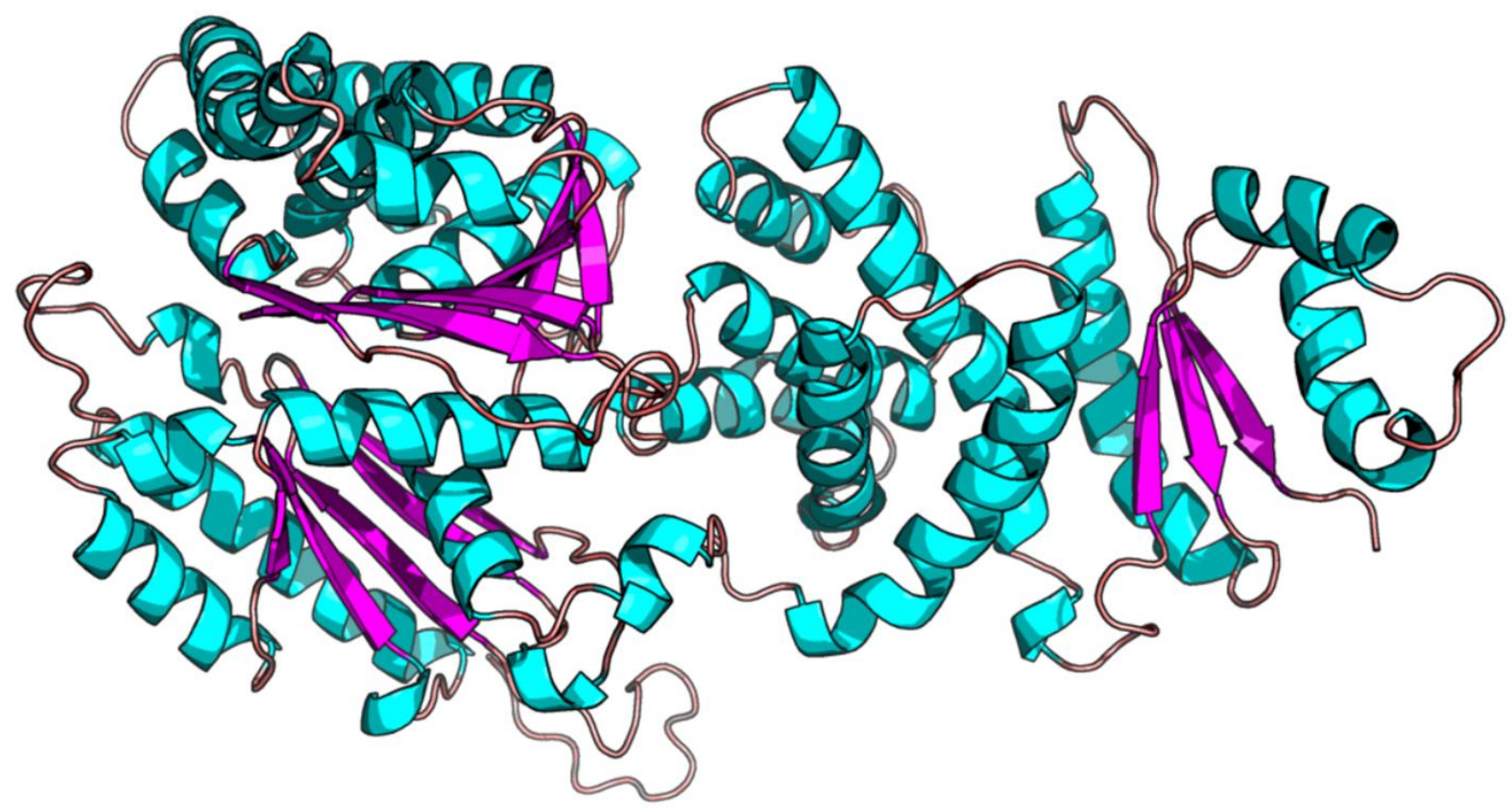

Figura 8 - Modelo de Rtg2p obtido pelo servidor Robetta (http://robetta.bakerlab.org/).

A partir do modelo, observou-se que a proteína é subdividida em três domínios (Figura 9), sendo que o domínio N-terminal já é conhecido, como mencionado acima, é muito similar ao domínio de ligação ao ATP das proteínas da família ASKHA (Acetato e quinase de açúcar/Hsp70p/Actina); por sua vez, o domínio central e o C-terminal de Rtg2p não possuem estruturas relacionadas na família PF02541. 


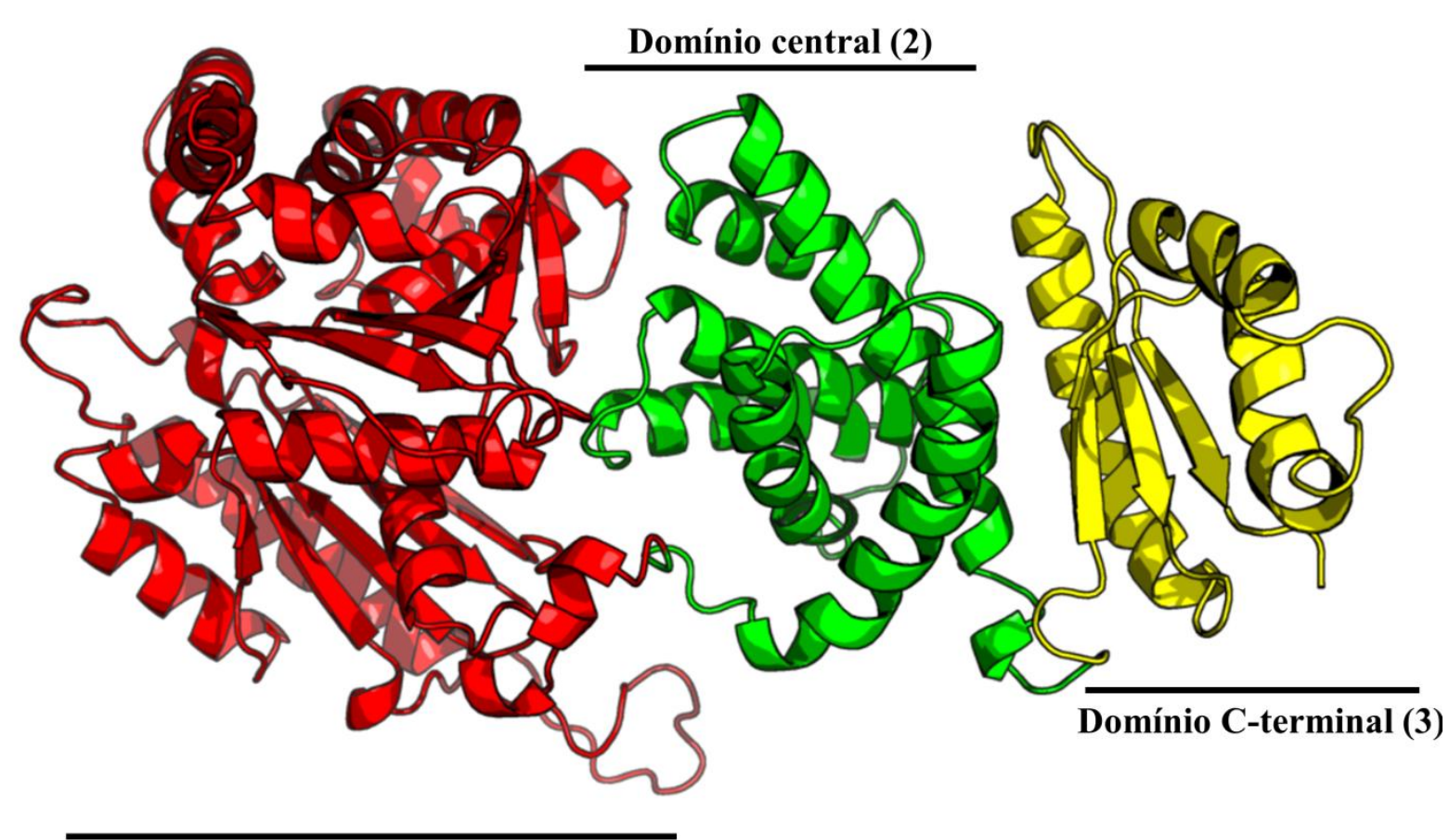

Domínio N-terminal (1)

Figura 9 - Modelo de Rtg2p, com os domínios em cores diferenciadas. (Em vermelho o domínio de ligação ao ATP N-terminal, em verde um domínio central todo $\alpha$, e um domínio C-terminal $\alpha \beta$ em amarelo).

Este modelo também permitiu indicar as comunidades de resíduos acoplados obtidas pelas análises do DRCN (Figura 10). Assim foi possível observar que as comunidades 1 (Figura 10A) e 2 (Figura 10B) possuem resíduos acoplados que estão distantes entre si; já na comunidade 3 (Figura 10C), os resíduos acoplados estão muito próximos (de frente um para o outro), entretanto, Rtg2p possui treonina e glutamina, enquanto que os demais membros da família possuem, predominantemente, alanina e glutamato nas mesmas posições relativas dessa comunidade. 
A

B

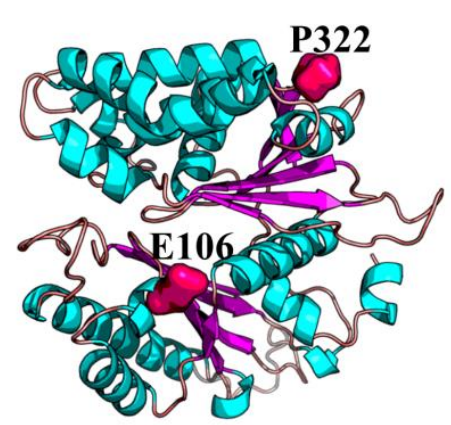

Comunidade 1
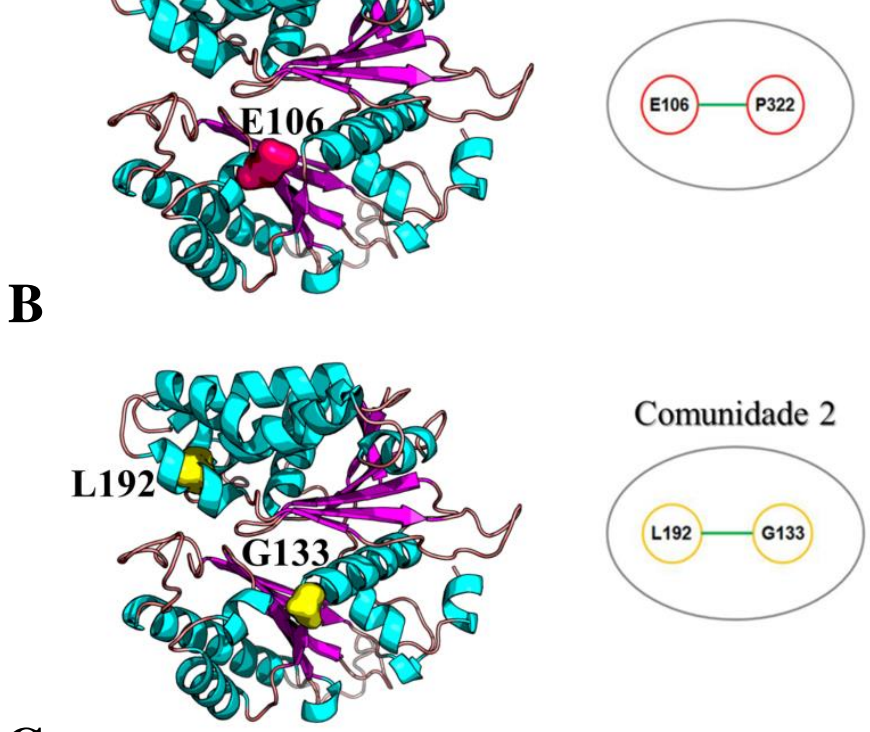

Comunidade 2

C

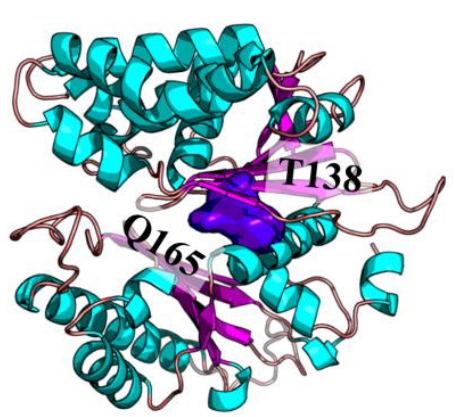

Comunidade 3

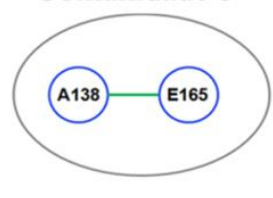

\begin{tabular}{|c|c|c|}
\hline Código UNIPROT & A263 & E423 \\
\hline RTG2_YEAST & T138 & Q165 \\
\hline A9CJF9_AGRT5 & A125 & E152 \\
\hline O67040_AQUAE & G120 & E148 \\
\hline PPX_ECO57 & A122 & E150 \\
\hline PPX_ECOLI & A122 & E150 \\
\hline Q11YA9_CYTH3 & A114 & E143 \\
\hline Q8G5J2_BIFLO & A118 & E149 \\
\hline Q8G5J2_BIFLO & A118 & E149 \\
\hline
\end{tabular}

Figura 10 - Localização dos resíduos das comunidades obtidas por DRCN no modelo de Rtg2p. A) Comunidade 1 , B) Comunidade 2 e C) Comunidade 3 . Na comunidade $3 \mathrm{Rtg} 2$ p possui resíduos completamente diferentes dos demais membros da família PF02541 (T138 e Q165, enquanto a maioria dos membros possui alanina e glutamato nas mesmas posições relativas - ver quadro ao lado). Os resíduos das comunidades estão indicados como superfícies no modelo. 
Indicou-se no modelo os resíduos conservados descritos na tabela 5 (Figura 11). Como esperado, todos estão no domínio N-terminal da proteína, já que somente esse domínio possui homólogos na família PF02541.

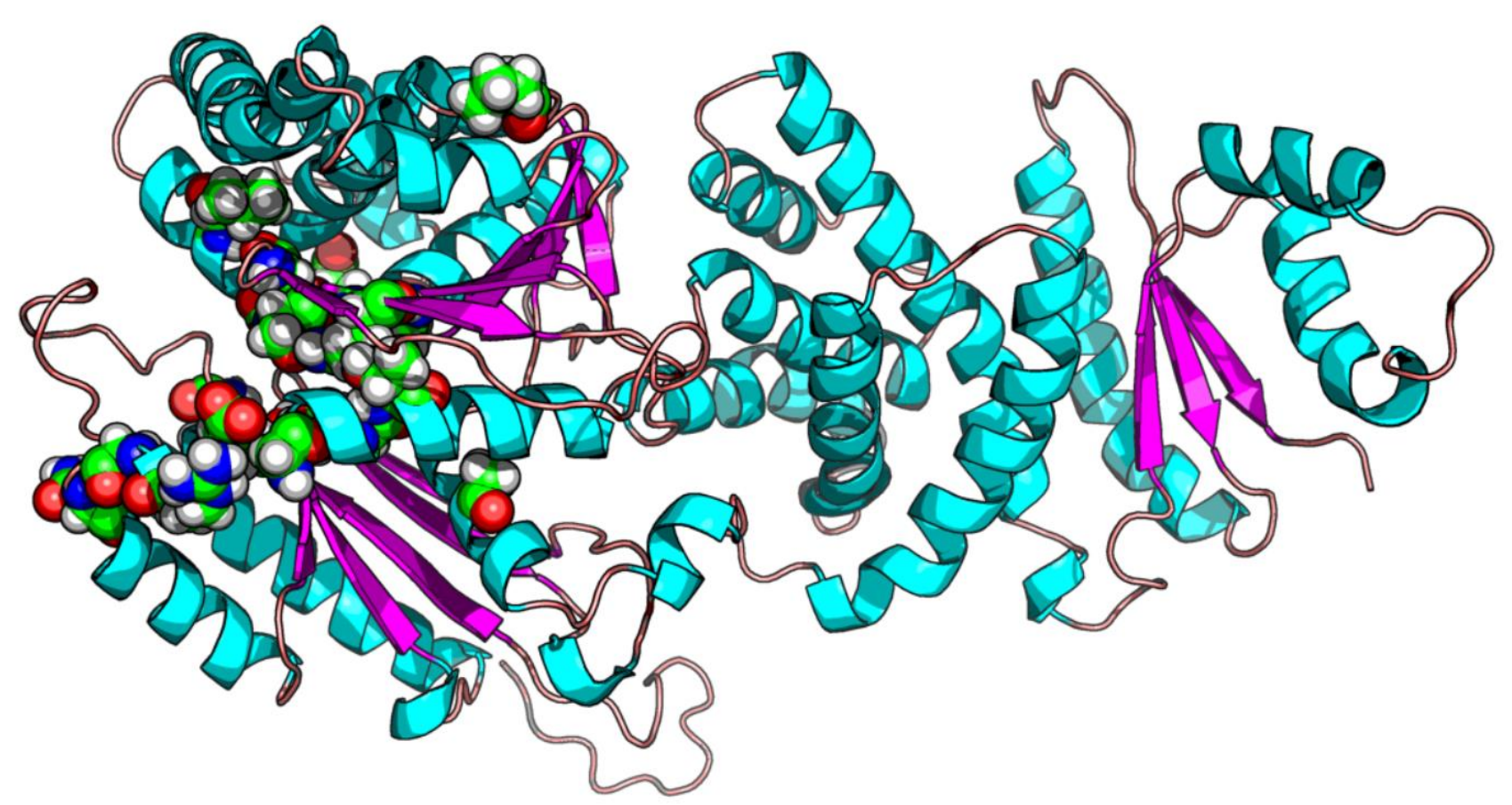

Figura 11 - Localização na estrutura tridimensional de Rtg2p dos resíduos com conservação superior a 90\% na análise DRCN da família PF02541. Os resíduos conservados estão indicados como esferas.

Todos os resíduos candidatos à mutação estão no N-terminal da proteína, que é um domínio de ligação ao ATP já conhecido da família das exopolifofatases. Sabe-se que esse domínio possui 5 motivos relacionados com regiões de ligação ao ATP denominados Phosphate 1, Phosphate 2, Connect 1, Connect 2, Adenosine, todos determinados a partir de alinhamento dos membros desta família. Os motivos Phosphate 1 e Phosphate 2 estão nas alças de ligação ao ATP, e juntamente com os outros motivos auxiliam essa ligação (BORK; SANDER; VALENCIA, 1992). Em 1994, Koonin realizou esse mesmo alinhamento, porém adicionando Rtg2p a ele, e foi possível observar os mesmos motivos em Rtg2p. Sabendo-se disso, identificaram-se os resíduos obtidos na análise de DRCN nos cinco motivos representado no modelo tridimensional de Rtg2p (Figura 12), e observou-se que alguns resíduos obtidos pela análise estão na região Phosphate 2 (D158, A160, G161, S163 e Q165) e Connect 1 (E137 e T138), sendo que Phosphate 2 está envolvida diretamente na ligação ao ATP. 
A

Phosphate 1

1 MSTLSDSDTE TEVVSRNLCG IVDIGSNGIR FSISSKAAHH ARIMPCVFKD RVGLSLYEVQ

61 YNTHTNAKCP IPRDIIKEVC SAMKRFKLIC DDFGVPETSV RVIATEATRD AINADEFVNA Connect 1

Phosphate 2

121 VYGSTGWKVE ILGQEDETRV GIYGVVSSFN TVRGLYLDVA GGSTQLSWVI SSHGEVKQSS

181 KPVSLPYGAG TLLRRMRTDD NRALFYEIKE AYKDAIEKIG IPQEMIDDAK KEGGFDLWTF Adenosine

241 GGGIPCMCHI LIYOSEGYPI OTIINGYACT YEEFSSMSDY LFLKOKIPGS Connect 2

301

IPOIKAVHFS EGGVREGSLY SLLPKEIRAO DPLLIASRPY

361 APLLTEKYLY LLRTSIPQED IPEIVNERIA PALCNLAFVH ASYPKELQPT AALHVATRGI

421 IAGCHGLSHR ARALIGIALC SRWGGNIPES EEKYSQELEQ VVLREGDKAE ALRIVWWTKY

481 IGTIMYVICG VHPGGNIRDN VFDFHVSKRS EVETSLKELI IDDANTTKVK EESTRKNRGY

541 EVVVRISKDD LKTSASVRSR IITLQKKVRK LSRGSVERVK IGVQFYEE*

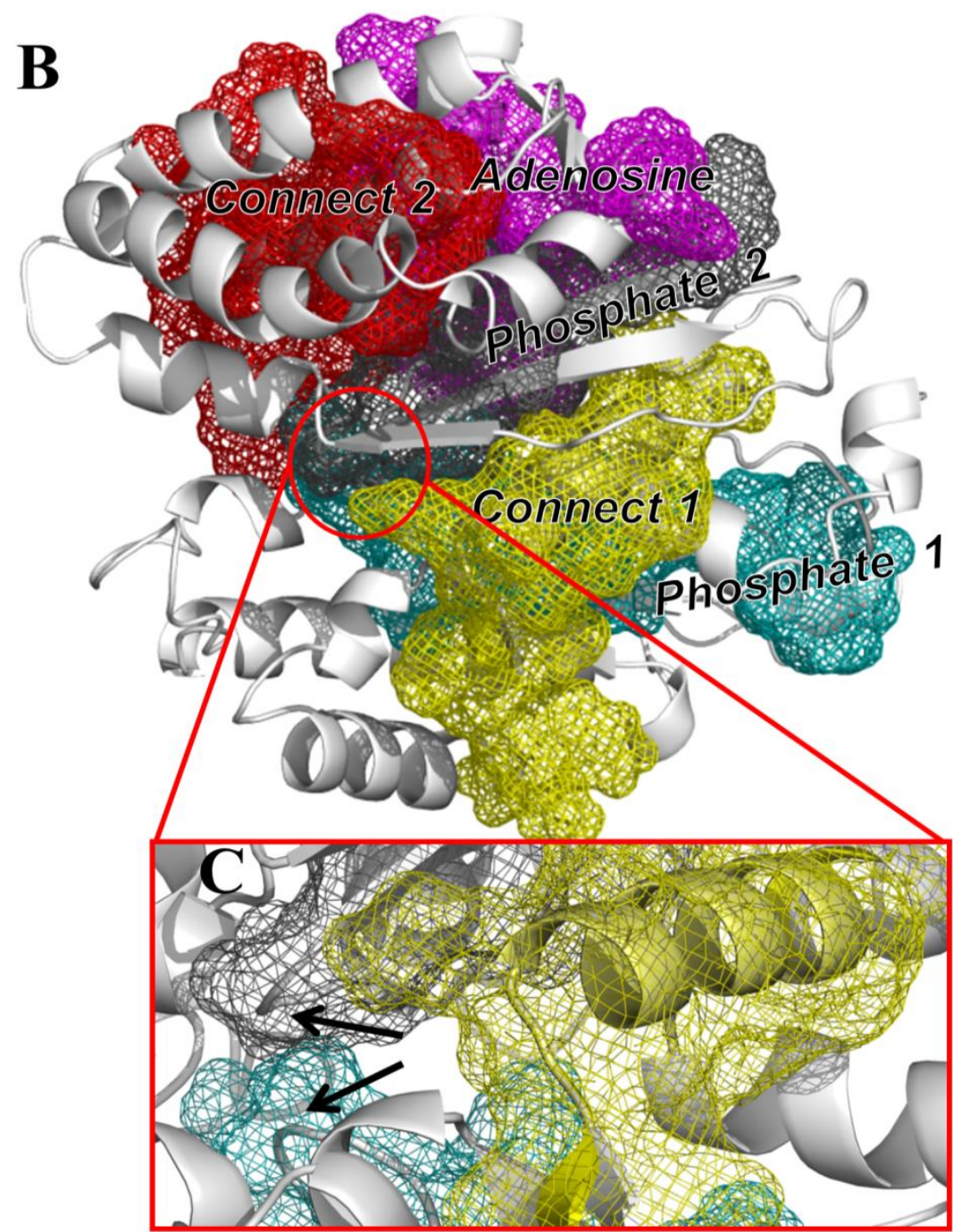

Figura 12 - Resíduos obtidos na análise de DRCN posicionados nos cinco motivos da família ASKHA representado no modelo tridimensional de Rtg2p. A: Sequência de aminoácidos de Rtg2p com indicações dos motivos de ligação ao ATP e os resíduos obtidos pelo DRCN indicados por um asterisco; B: N-terminal de Rtg2p com indicações dos motivos de ligação ao ATP; C: Alças de ligação ao ATP indicadas por setas. 


\subsection{Hipótese das interações dos resíduos conservados e/ou coevoluídos na estrutura de Rtg2p}

As análises obtidas por DRCN apontaram 21 resíduos candidatos para produzir mutantes pontuais em Rtg2p, porém, ainda assim, este era um número elevado de mutantes. Levando em consideração o modelo produzido, a localização dos resíduos e os motivos de ligação ao ATP, elaboraram-se hipóteses de interação para os resíduos conservados (Tabela 8). e que coevoluiram (Tabela 9) identificados em Rtg2p

A partir dessas hipóteses de interação e da distribuição dos resíduos no modelo de Rtg2p, escolheu-se oito resíduos conservados para realizar mutagênese sítio-dirigida. Os resíduos escolhidos foram L56, R109, N113, E137, D158, A160, G161 e S163 (Figura 13A), pois sua distribuição abrange a maior região em torno das alças de ligação ao ATP.

Elaboraram-se hipóteses de interação para os resíduos que coevoluiram em $\operatorname{Rtg} 2 p$ (Tabela 9). Escolheram-se os resíduos E106, T138 e Q165 para realização da mutagênese sítio-dirigida; que são resíduos da comunidade 3 (T138 e Q165), e o resíduo E106 todos localizados muito próximos da região de ligação do ATP, já que os outros resíduos conservados estão muito na periferia da proteína (Figura 13B). Ao total foram escolhidos treze resíduos para mutagênese (Tabela 10). 
Tabela 8 - Hipóteses para interação dos resíduos conservados

\begin{tabular}{l} 
Resíduo Hipóteses \\
\hline L56 \\
L56 está localizada entre a folha beta 3 e alfa hélice 2, em uma região rica \\
em resíduos hidrofóbicos de cadeia longa (I75 e $\mathrm{V79}$ ), sendo possível a \\
interação principalmente com 124 que está no início da alça de ligação ao \\
ATP (Entre a fita $\beta 2$ e $\beta 3$ ). Alterar para um aminoácido com a mesma \\
propriedade, porém em tamanho reduzido talvez aumente a mobilidade \\
dessa região. \\
T105 está próximo ao resíduo conservado E137, talvez poderia ocorrer uma \\
interação entre esses resíduos por ponte de hidrogênio. Troca por alanina \\
romperia esse interação. \\
R105 \\
R109 está totalmente exposta ao solvente na superfície de Rtg2p e pode \\
aumentar a solubilidade local ou interação com outra proteína. Trocar a \\
carga pode alterar essas prováveis interações.
\end{tabular}


A111 A111 está em um loop e aumenta a rigidez entre as hélice 4 e 5. Mutação para glicina nesse resíduo pode aumentar a mobilidade dessa hélice.

N113 N113 está exposta ao solvente na superfície de Rtg2p, e provavelmente aumenta a solubilidade local. Trocar a polaridade altera as prováveis interações com o solvente.

E137 A posição de E137 é responsável por coordenar o íons $\mathrm{Mg}^{2+}$ em outros membros da família. Alterar para alanina, provavelmente, poderia impedir a coordenação do $\mathrm{Mg}^{2+}$ e a ligação ao ATP.

D158 D158 está próximo à alça de ligação ao ATP, porém não se consegue obter uma hipótese óbvia para testar sua importância. Pode-se, entretanto, realizar a alteração padrão para alanina.
$A 111 G$

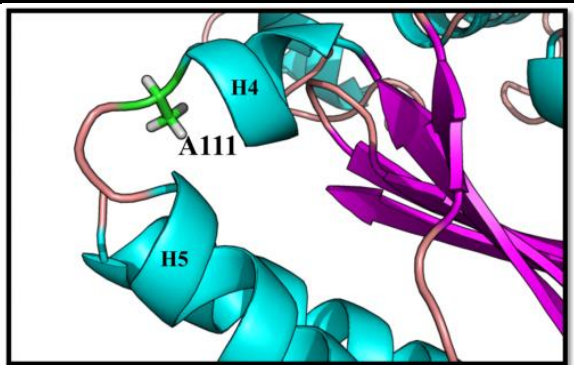

N113A

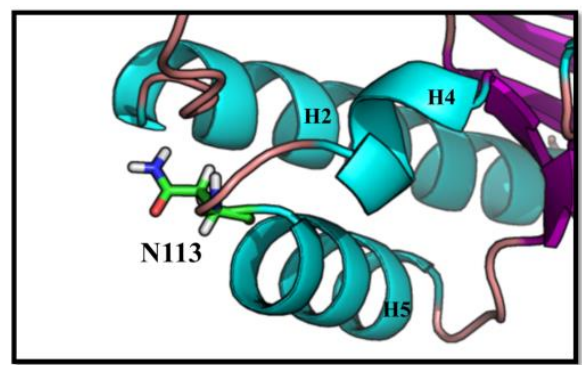

$E 137 A$

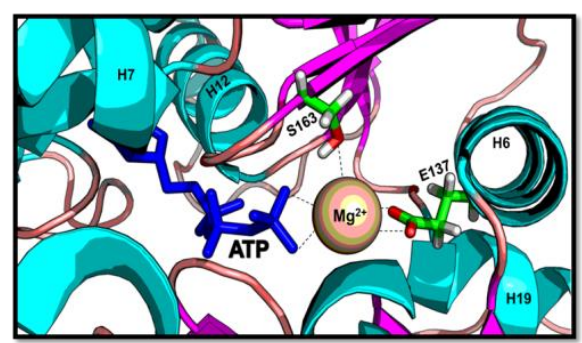

$D 158 A$

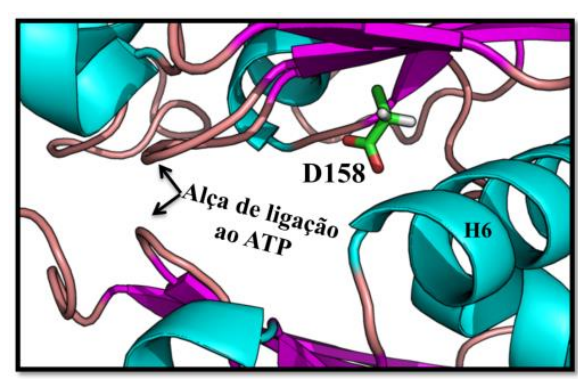




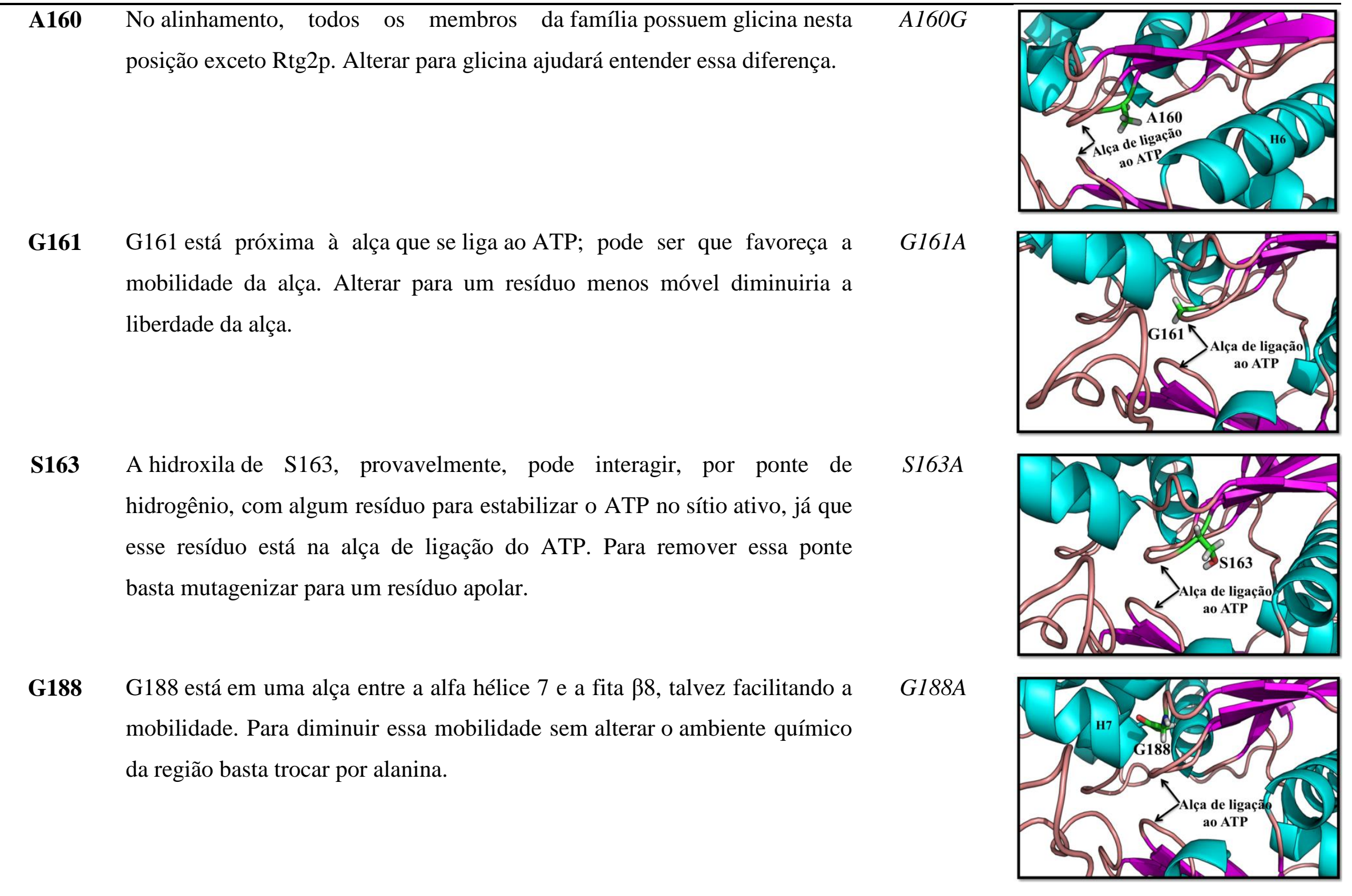


R303 R303 está voltada para alça de ligação ao ATP e por ter a carga positiva poderia atrair o ATP para o sítio ativo. Mutagenizar para um aminoácido de carga oposta pode verificar essa provável interação.

G337 G337 é um resíduo estrutural da alfa hélice 14. Como não aumenta muito a interação com a hélice 6 , não se consegue obter uma hipótese óbvia para testar sua importância. Pode-se, entretanto, realizar a alteração padrão para alanina.

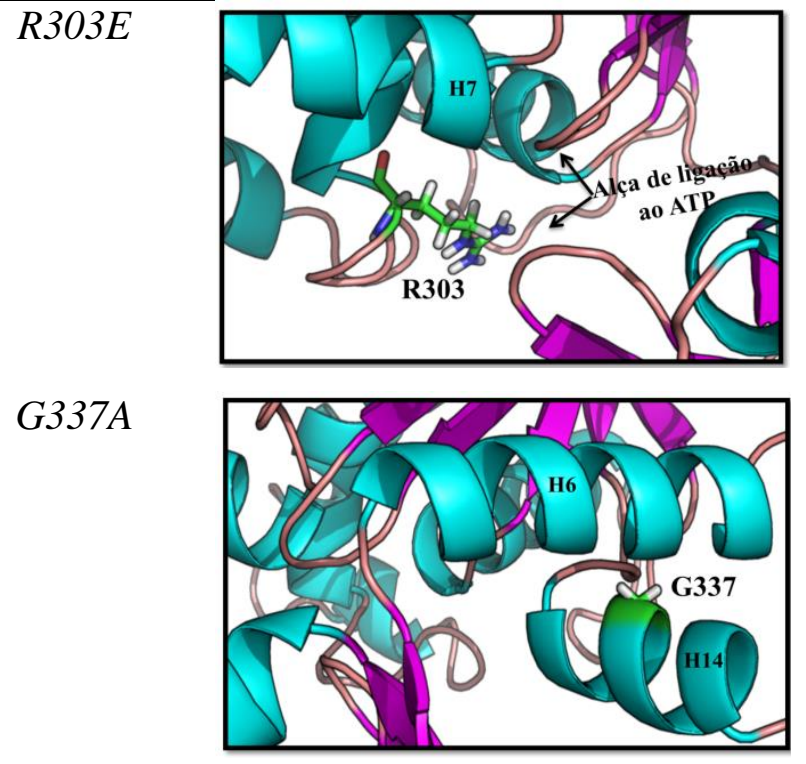


Tabela 9 - Hipóteses de interação para os resíduos acoplados de Rtg2p.

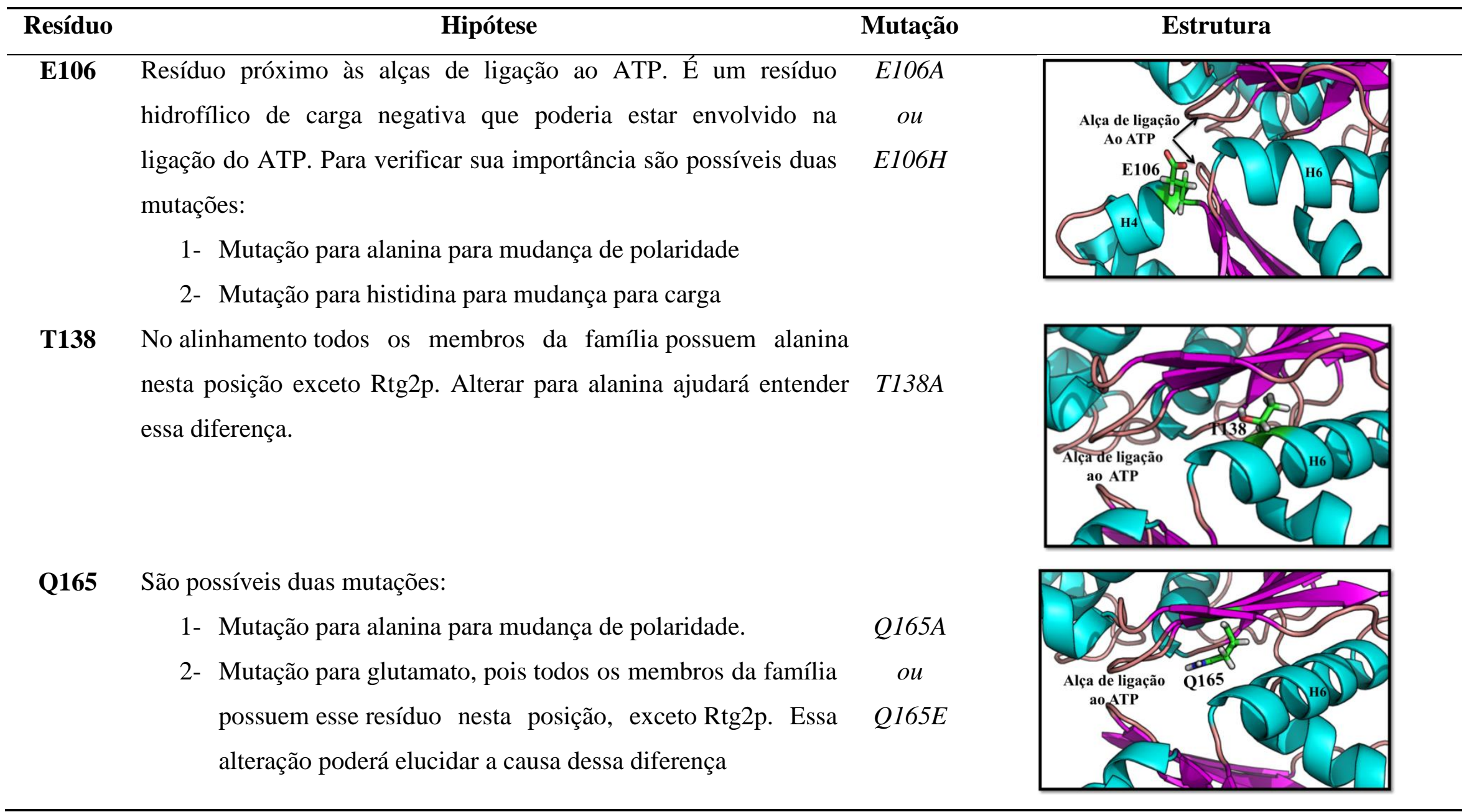



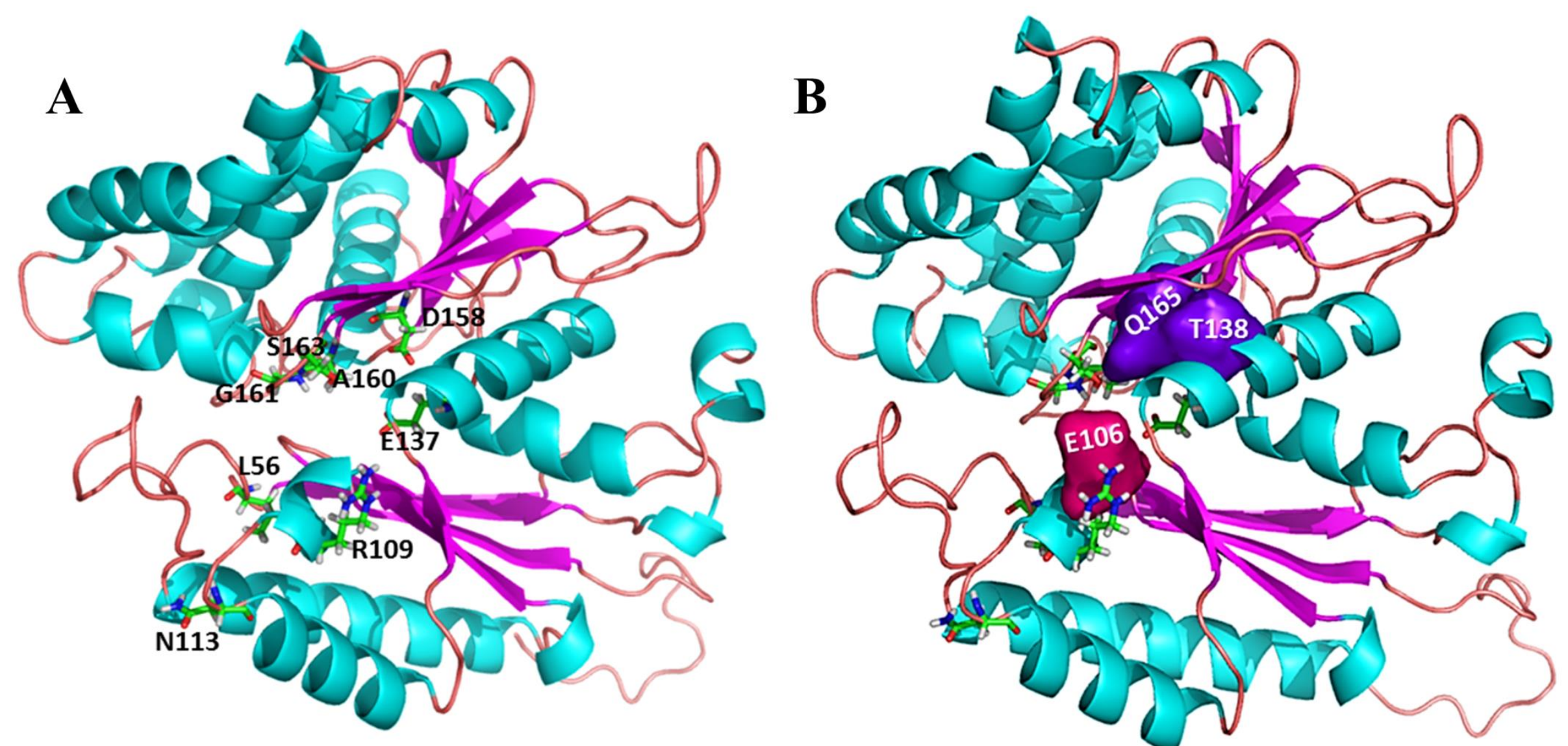

Figura 13 - Resíduos para mutagênese sítio-dirigida no N-terminal de Rtg2p; A: N-terminal de Rtg2p com resíduos conservados indicados; B: N-terminal de Rtg2p com resíduos coevoluidos indicados. 


\subsection{Rompimento do gene $R T G 2$}

Com todos os resíduos escolhidos para mutagênese sítio-dirigida, foi necessário a construção da cepa $\operatorname{rtg} 2 \Delta$, para posterior substituição gênica dos mutantes pontuais. Por isso construiu-se um cassete de rompimento composto pela região codificadora do gene T-urfl3 de Zea mays flanqueado pelo promotor e terminador da fosfoglicerato kinase de levedura $(P G K 1)$, clonado adjacente ao gene que confere resistência à geneticina (KanMX). Após integração deste cassete, a cepa resultante deve ser resistente a geneticina (G418) e sensível ao carbamato metomil.

Com a finalidade de romper o gene $R T G 2$, o cassete de rompimento $\operatorname{rtg} 2:: \mathrm{URF} 13-$ KanMX foi amplificado por PCR e a cepa PSY142 transformada e plaqueada em placas contendo geneticina. Dois transformantes foram selecionados, a fim de confirmar a integração no locus de $R T G 2$ por PCR, utilizando-se os pares de oligonucleotídeos rtg2-597up-F/KanB (produto de 3000pb) e KanC/rtg2-2217down-F (produto de 1000pb) (Figura 14C). Ambos os transformantes apresentaram integração no locus correto. Como a cepa $\operatorname{rtg} 2 \Delta$ deveria apresentar sensibilidade ao metomil e resitência a G418, foram feitos ensaios de crescimento para confirmar esses fenótipos, que também foram confirmados (Figura 14B, painel superior).

Mutantes $r \operatorname{tg} 2 \Delta$ são auxotróficos para glutamato, quando crescidos em meio mínimo na ausência deste aminoácido. Para verificar o rompimento de RTG2 também foi utilizado esse parâmetro, para isso os transformantes foram crescidos na presença (YNBD+) e na ausência (YNBD) de glutamato. Todos os transformantes analisados são auxotróficos para glutamato (Figura 14B, painel inferior). 
A
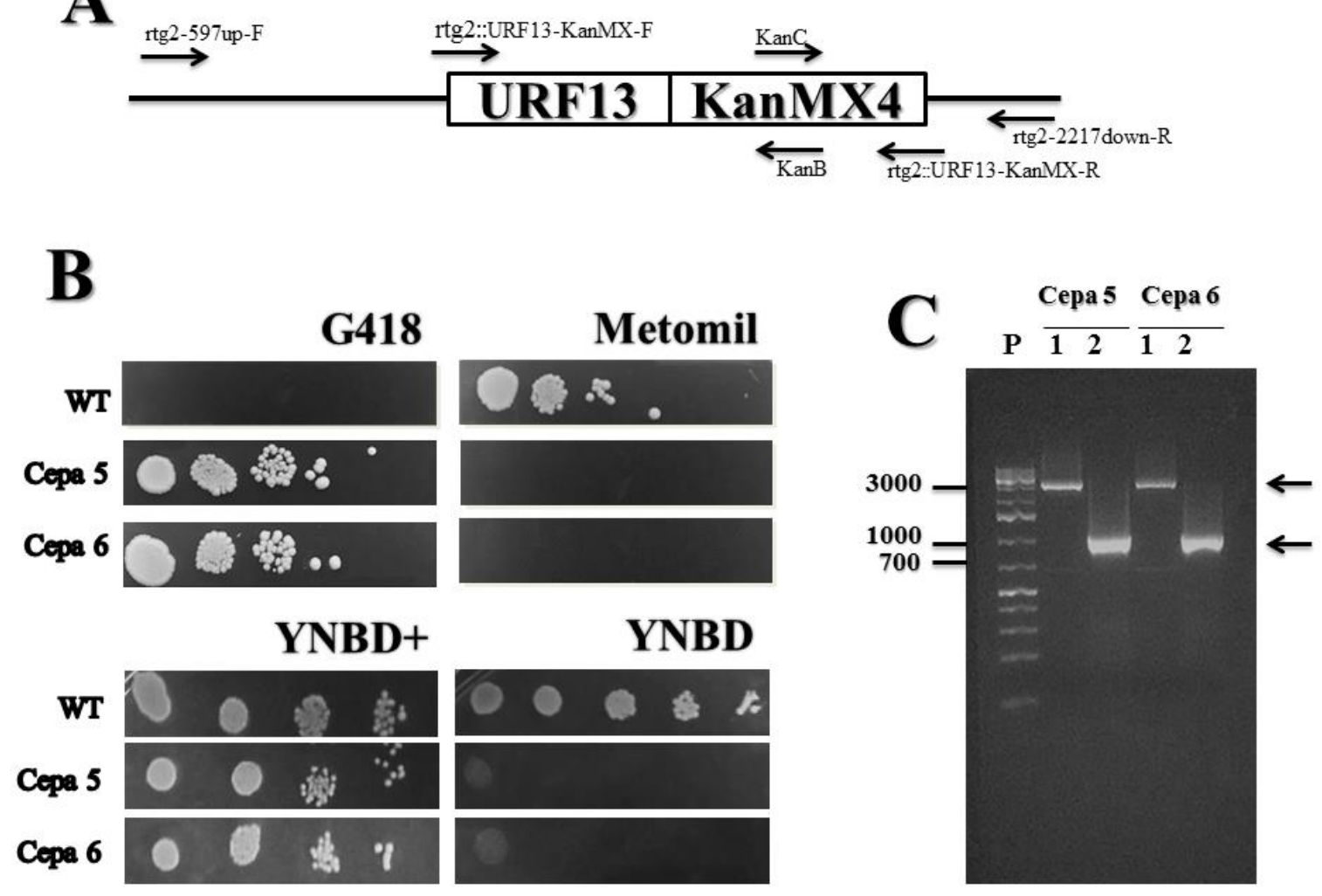

Figura 14 - Rompimento do gene RTG2 com o cassete rtg2::URF13-KanMX. A: Localização dos primers para confirmação do lócus de integração (primers indicados), B: Ensaio de diluição seriada para confirmação resistência à geneticina $(\mathrm{G} 418-200 \mu \mathrm{g} / \mathrm{mL})$, sensibilidade ao metomil $(6 \mathrm{mM})$ (painel suerior) e auxotrofia para glutamato (painel inferior), C: confirmação do lócus de integração em duas cepas transformantes. As canaletas indicadas com "1"correspondem à amplificação com os primers rtg2-597up-F e KanB (300pb). As canaletas indicadas com "2"correspondem à amplificação com os primers KanC e rtg2-2217down-F(1000pb).

Com essa linhagem obtida foi possível à substituição alélica de todos os mutantes pontuais no locus de RTG2. A vantagem deste método é que a cepa resultante tem como única diferença da selvagem a mutação pontual introduzida.

\subsection{Clonagem dos mutantes pontuais de Rtg2p baseados na análise DRCN}

A partir das análises por DRCN juntamente com as hipóteses de interações estruturais foram construídos 13 mutantes pontuais (Tabela 10) através de mutagênese sítio-dirigida, que realiza mutação em um aminoácido especifico por sobreposiçao de PCRs (overlap extension $P C R)$ (Figura 4). 
Tabela 10- Resíduos de aminoácido de Rtg2p que foram alterados por mutagênese sítio-dirigida.

\begin{tabular}{cc}
\hline Mutação & Códons Modificados \\
\hline L56G & CTA $\rightarrow$ GGA \\
E106H & GAA $\rightarrow$ CAT \\
E106A & GAA $\rightarrow$ GCA \\
R109E & CGA $\rightarrow$ GAA \\
N113A & AAC $\rightarrow$ GCC \\
E137A & GAA $\rightarrow$ GCA \\
T138A & ACT $\rightarrow$ GCT \\
D158A & GAT $\rightarrow$ GCT \\
A160G & GCA $\rightarrow$ GGA \\
G161A & GGT $\rightarrow$ GCT \\
S163A & AGT $\rightarrow$ GCT \\
Q165E & CAG $\rightarrow$ GAG \\
Q165A & CAG $\rightarrow$ GCG \\
\hline
\end{tabular}

Obtivemos por PCR todas as mutações pontuais selecionadas (Anexos: Figura A1 e A2), os produtos de PCR foram digeridos com as enzimas de restrição presentes nas extremidades 5' (HindIII) e 3' (BamHI), clonados no vetor pGEM-3Zf(+) (Anexos: Figura A3) e sequenciados no Centro de Pesquisas sobre o Genoma Humano e Células-Tronco. O resultado do sequenciamento confirmou a presença da mutação pontual produzida em cada mutante e a ausência de mutações adicionais em locais não específicos (Anexos: Figura A4 e A5). 


\subsection{Substituição gênica dos mutantes no locus de RTG2}

Realizou-se substituição gênica com os mutantes obtidos na cepa PSY142 rtg2::URF13-KanMX. Após transformação em meio rico na presença de metomil, os clones obtidos foram submetidos a PCR para confirmação do locus de integração para confirmar da perda do cassete URF13-KanMX (Figura 15).

A

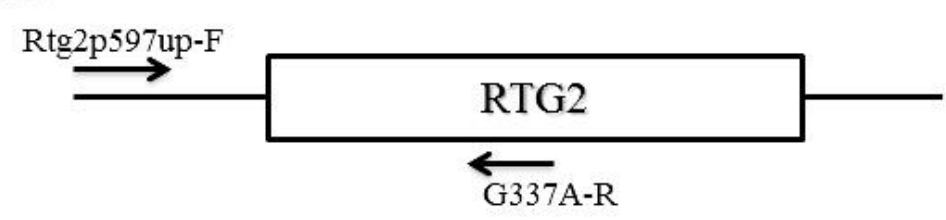

B
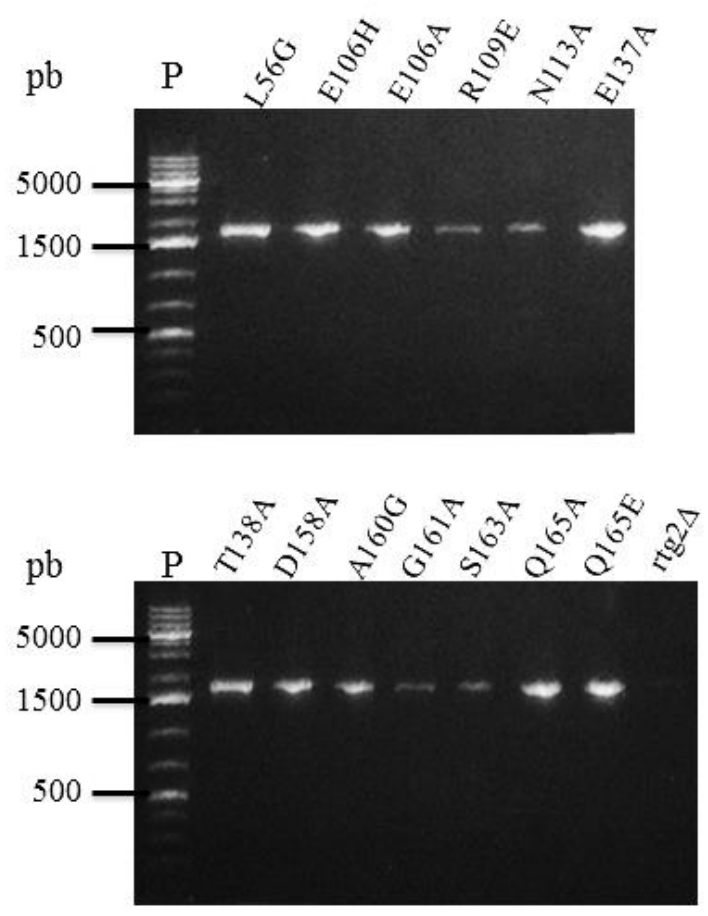

Figura 15 - Substituição gênica de rtg2::URF13-KanMX pelos mutantes pontuais de RTG2. A: Estratégia da PCR para confirmação do locus de integração com os primers rtg2-597up-F e rtg2-G337A-R (produto com: $1532 \mathrm{pb}), \mathbf{B}$ : eletroforese da confirmação do locus de integração em todas cepas transformantes. 


\subsection{Análise auxotrófica dos mutantes}

A sinalização retrógrada depende do gene $R T G 2$ para a translocação dos fatores de transcrição Rtg1p e Rtg3p para o núcleo, onde ativam a transcrição de genes cujas proteínas participam da biossíntese de glutamato. A ausência de glutamato ativa a via de sinalização retrógrada e a presença de glutamato a reprime. Por essa razão cepas $\operatorname{rtg} 2 \Delta$ são auxotróficas para esse aminoácido, quando crescidas em meio mínimo YNBD. Para analisar essa auxotrofia nos mutantes produzidos, cresceram-se as células até a fase estacionária e foram feitas diluições seriadas múltiplas de 10 em placas YNBD na ausência ou presença de glutamato (Figura 16).

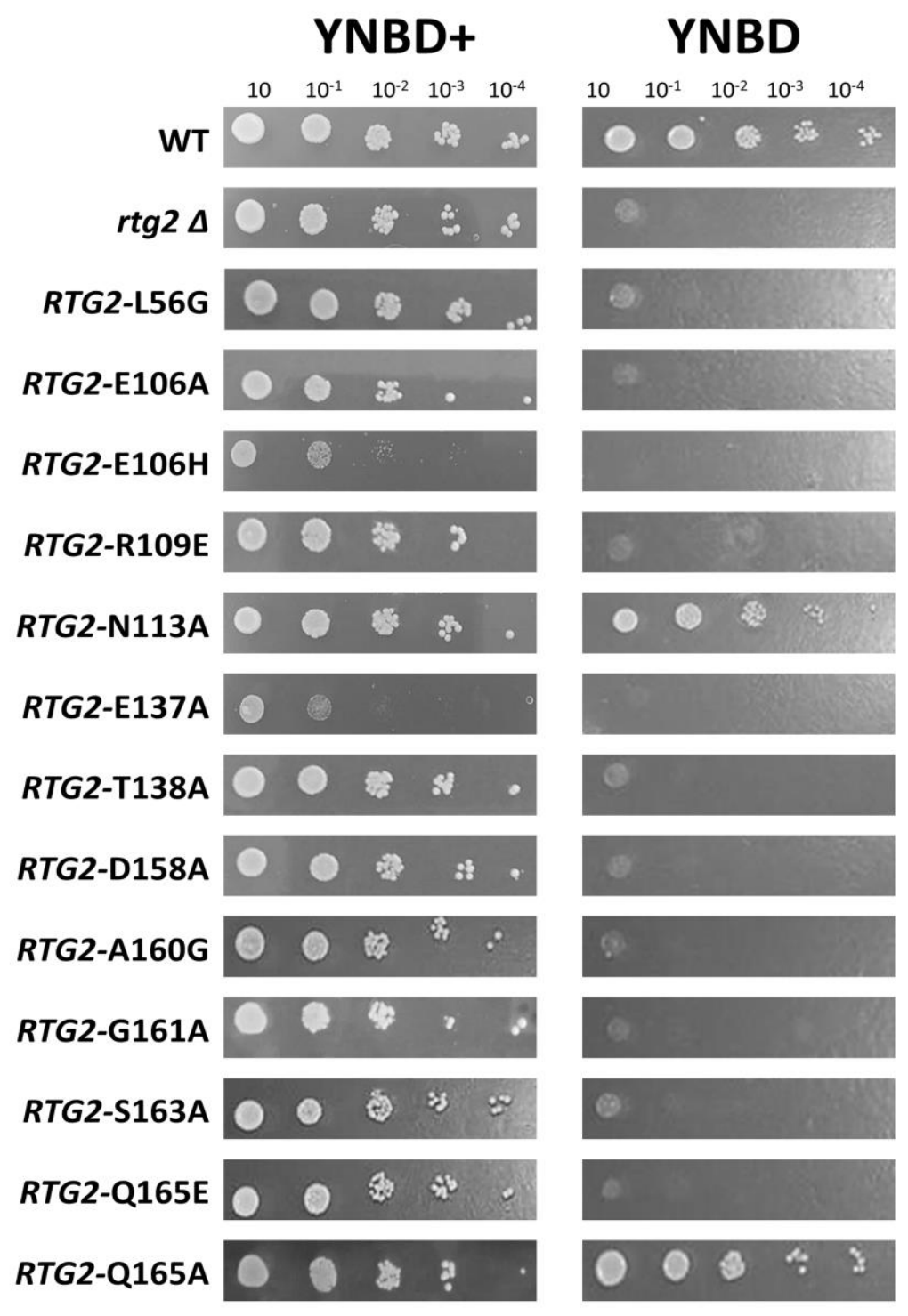

Figura 16 - Mutações pontuais em Rtg2p causam auxotrofia para glutamato. Ensaio de crescimento em meio mínimo YNBD e YNBD+ (glutamato 0,02\%). As cepas selvagem (WT), mutante $r$ tg2 $2 \Delta \mathrm{e}$ mutantes pontuais em RTG2 foram crescidas a $\mathrm{A}_{600}=1$ e realizou-se 4 diluições seriadas $\left(10^{-1}, 10^{-2}, 10^{-3}\right.$ e $\left.10^{-4}\right)$ aplicadas em placas YNBD e YNBD+. As placas foram fotografadas após 3 dias a $30{ }^{\circ} \mathrm{C}$. 
Após três dias em meio mínimo, exceto as cepas N113A e Q165A, todas as outras cepas mutantes mostraram-se auxotróficas para glutamato, apresentando o mesmo fenótipo da cepa $\operatorname{rtg} 2 \Delta$; portanto, a alteração desses aminoácidos causou inativação da função da proteína na sinalização retrógrada. É possível observar também que as cepas E106H e E137A apresentaram dificuldade no crescimento mesmo na presença de glutamato. A fim de comprovar os resultados obtidos em placa, as cepas foram crescidas em meio líquido e sua absorbância $(600 \mathrm{~nm})$ medida durante 24 horas para obtenção da curva de crescimento (Figura 17). 


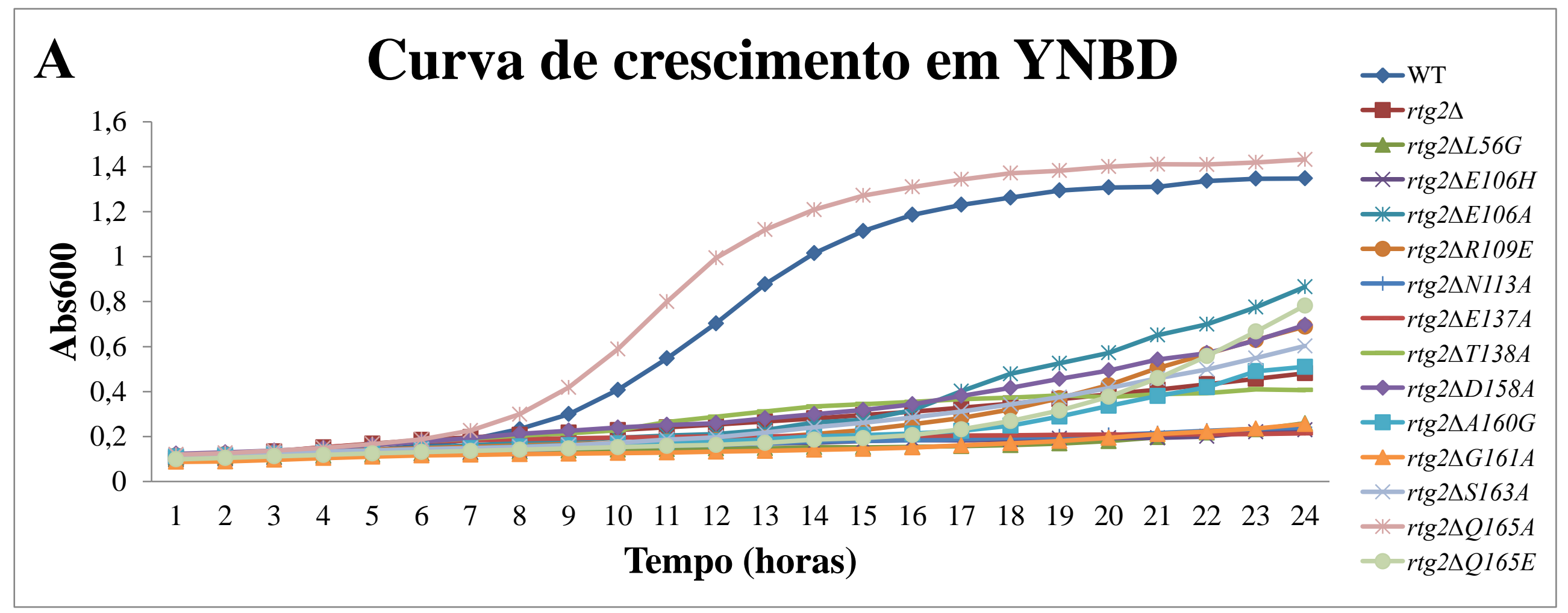




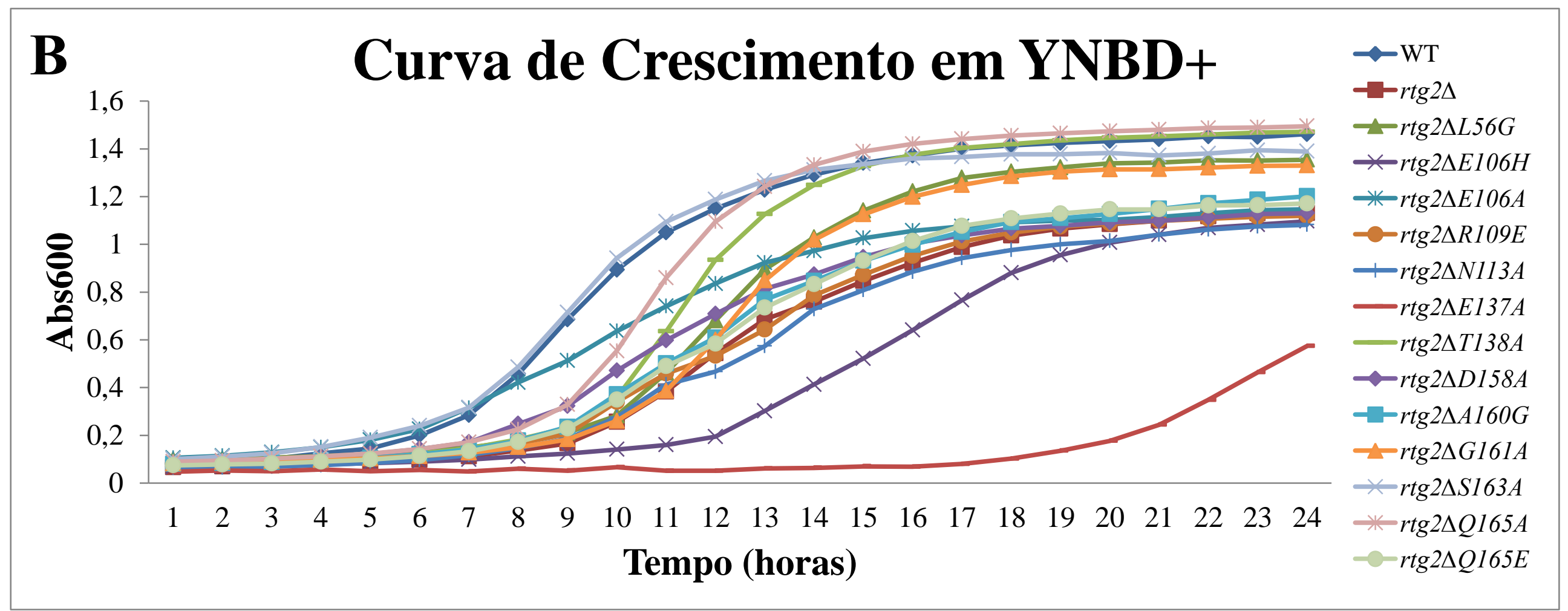

Figura 17 - Mutantes pontuais em Rtg2p causam prejuízo no crescimento. Ensaio de crescimento em meio mínimo líquido das cepas mutantes pontuais em RTG2;A: Meio YNBD na ausência de glutamato; B: YBND+ com adição de 0,02\% de glutamato. As células foram crescidas em YPD até saturação e inoculadas em $200 \mu \mathrm{L}$ dos meios indicados na $\mathrm{A}_{600}$ inicial de 0,1 . As curvas foram obtidas após $24 \mathrm{~h}$ de incubação a $30{ }^{\circ} \mathrm{C}, 160 \mathrm{rpm}$ na incubadora/leitora de placa INFINITY PRO 200 (Tecan). 
Em $24 \mathrm{~h}$ de crescimento na ausência de glutamato, todos mutantes apresentaram o mesmo comportamento observado em meio sólido, as cepas N113A e Q165A não se mostraram auxotróficas para glutamato e as outras cepas mutantes apresentam auxotrofia para este aminoácido tendo fenótipo similar ao da cepa $r t g 2 \Delta$ (Figura 17). É possível observar que as cepas E106H e E137A apresentaram uma dificuldade no crescimento mesmo na presença de glutamato, sendo que E137A tem a fase lag estendida.

\subsection{Análise da ativação da sinalização retrógrada dependente de Rtg2p}

A cepa PSY142 utilizada e as cepas mutantes em RTG2 obtidas possuem integradas em seu genoma a construção CIT2-LacZ. CIT2 é o gene prototípico da sinalização retrógrada e sua ativação ocorre em meio mínimo YNBD, na ausência de glutamato. A presença deste aminoácido inibe-se a expressão de CIT2. Para analisar o efeito das mutações pontuais de $R T G 2$ na expressão gênica de CIT2, mediu-se a expressão do gene repórter $\beta$-galactosidase (Figura 18). 


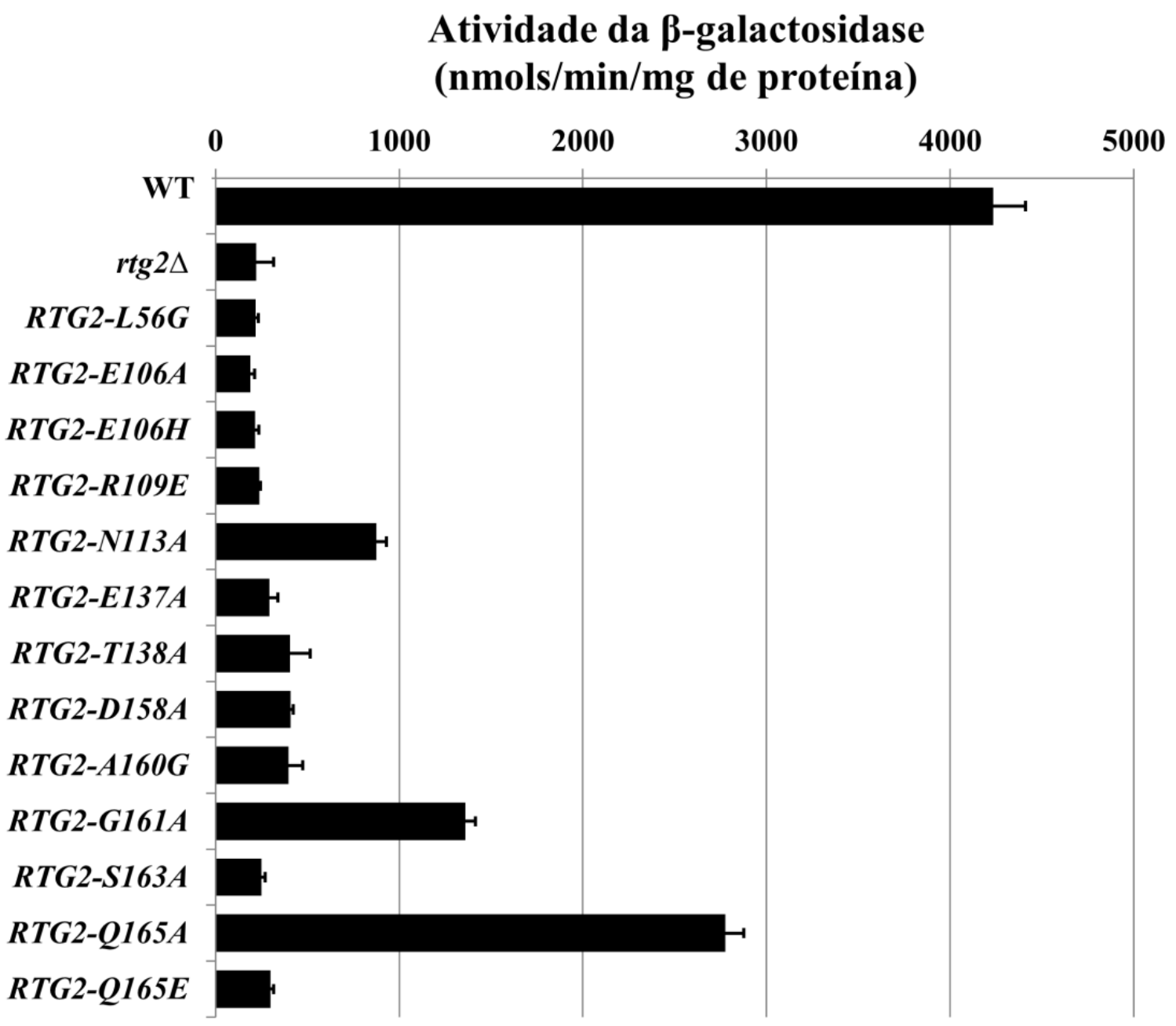

Figura 18 - Mutantes pontuais de Rtg2p apresentam baixa expressão de CIT2-LacZ. Análise da expressão de CIT2-LacZ integrado na cepa selvagem e mutantes. Extratos celulares foram preparados de células crescidas até $\mathrm{A} 600=0,6 \mathrm{em}$ meio YNBD e a atividade $\beta$-galactosidase foi medida e normalizada pela concentração de proteína total.

Pode-se observar que a maioria dos mutantes teve a atividade $\beta$-galactosidásica similar à da cepa $\operatorname{rtg} 2 \Delta$. Entretanto, as cepas N113A e G161A apresentaram uma atividade de 3 a 4 vezes maior que a cepa $\operatorname{rtg} 2 \Delta$. Destaca-se também a cepa mutante Q165A, que manteve atividade residual em 65,54\% em relação à cepa WT. Esses resultados indicam que os resíduos fornecidos pela análise DRCN, selecionados para mutagênese sítio-dirigida, em sua maioria, produziram perturbação severa na função de Rtg2p. 


\subsection{Análise da Longevidade Replicativa dos mutantes de RTG2}

Cepas $\operatorname{rtg} 2 \Delta$ apresentam longevidade reduzida. Para verificar o efeito das mutações em $R T G 2$ sobre a o envelhecimento foi realizado um ensaio de longevidade replicativa (Figura 19 a 22).

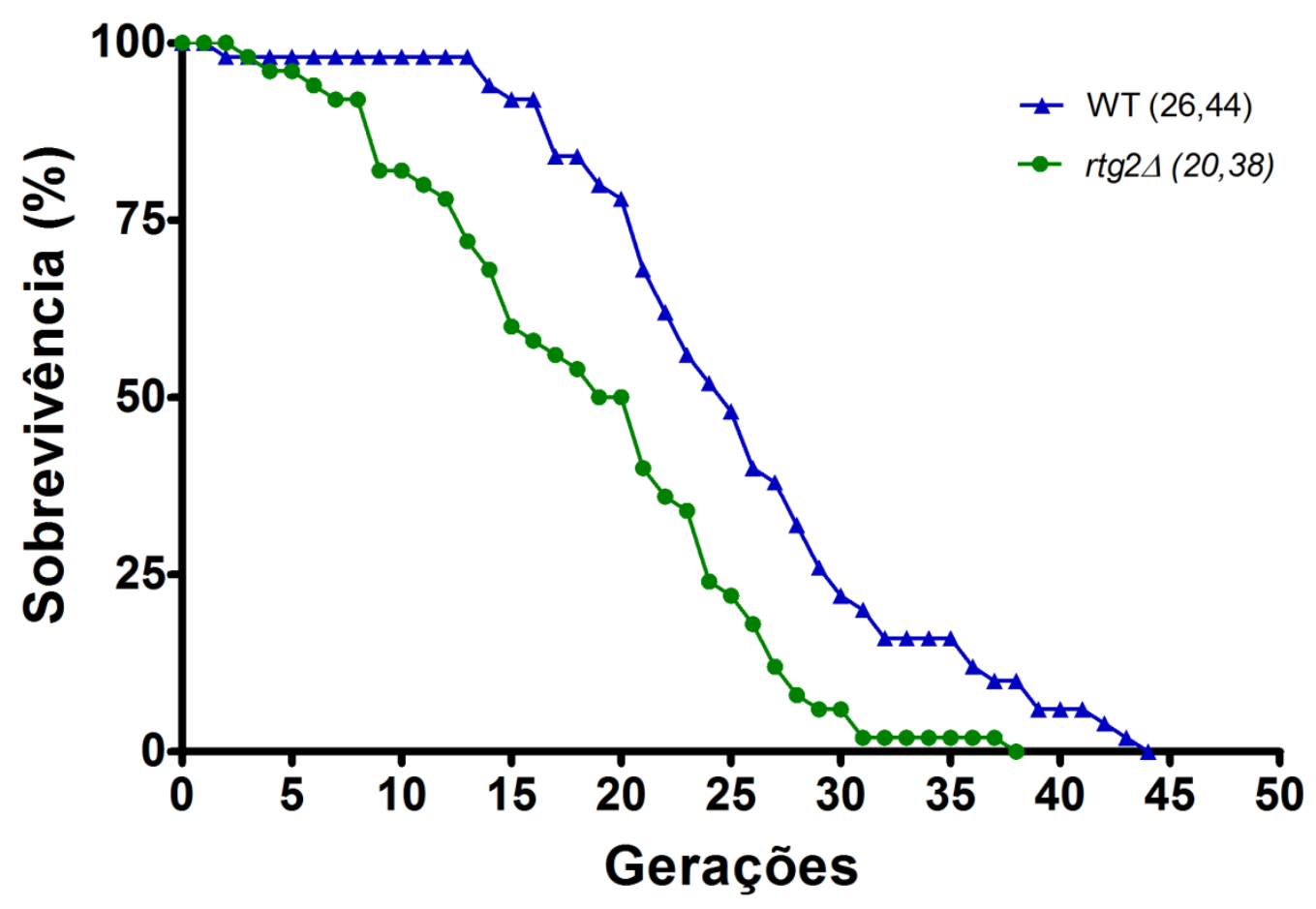

Figura 19 - Deleção de $\boldsymbol{R T G 2}$ reduz longevidade replicativa. Foram alinhadas 50 células de cada cepa em uma placa YPD, e as células-filhas foram removidas das mães para a construção da curva de sobrevivência. As longevidades média e máxima estão indicadas em parênteses (Média, Máxima). A significância estatística está indicada na tabela A1 (Anexos). 

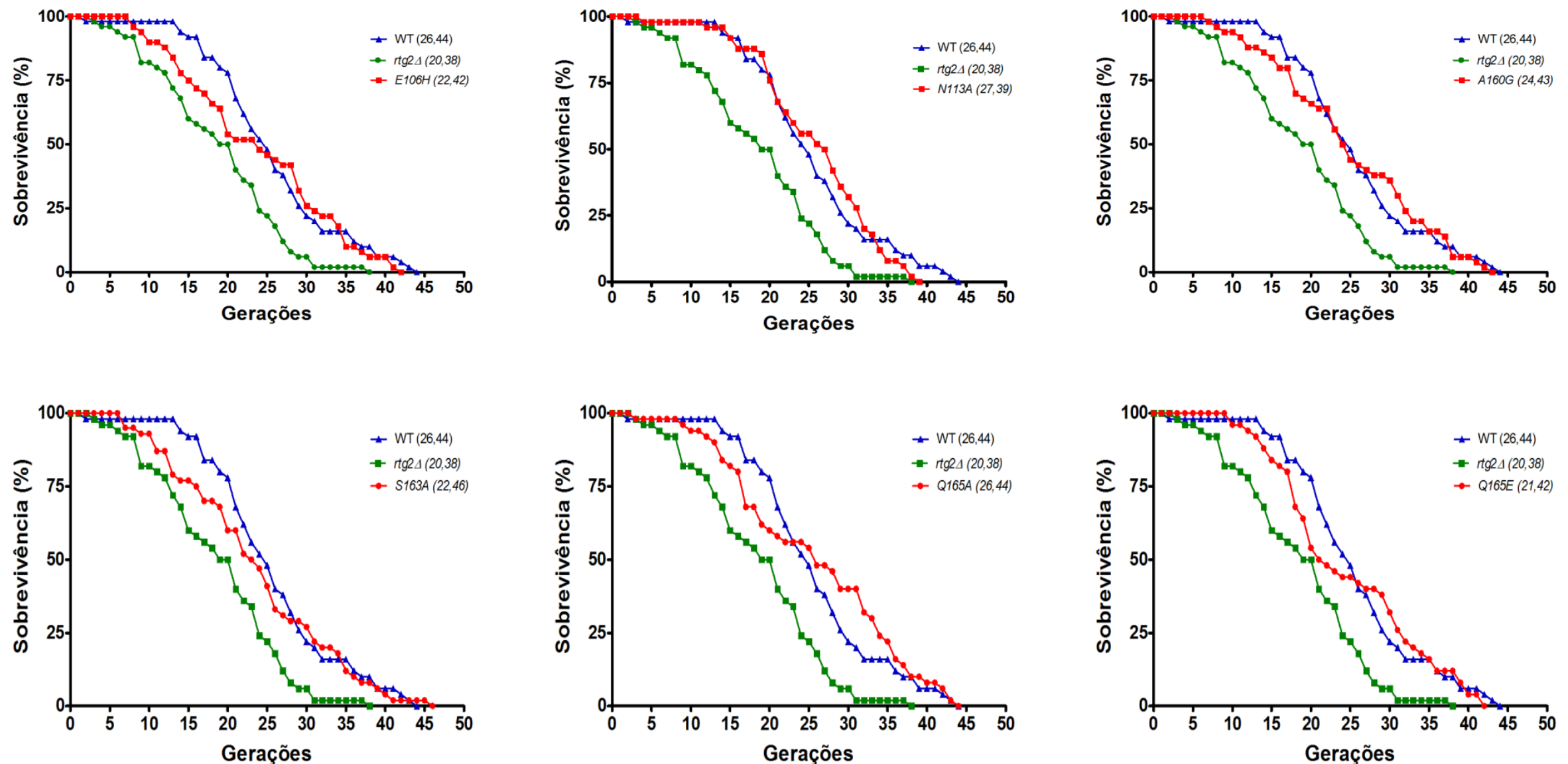

Figura 20 - Mutações pontuais não comprometem longevidade replicativa da célula. Foram alinhadas 50 células de cada cepa em uma placa YPD, e as células-filhas foram removidas das mães para a construção da curva de sobrevivência. As longevidades média e máxima estão indicadas em parênteses (Média, Máxima). A significância estatística está indicada na tabela A1(Anexos). 

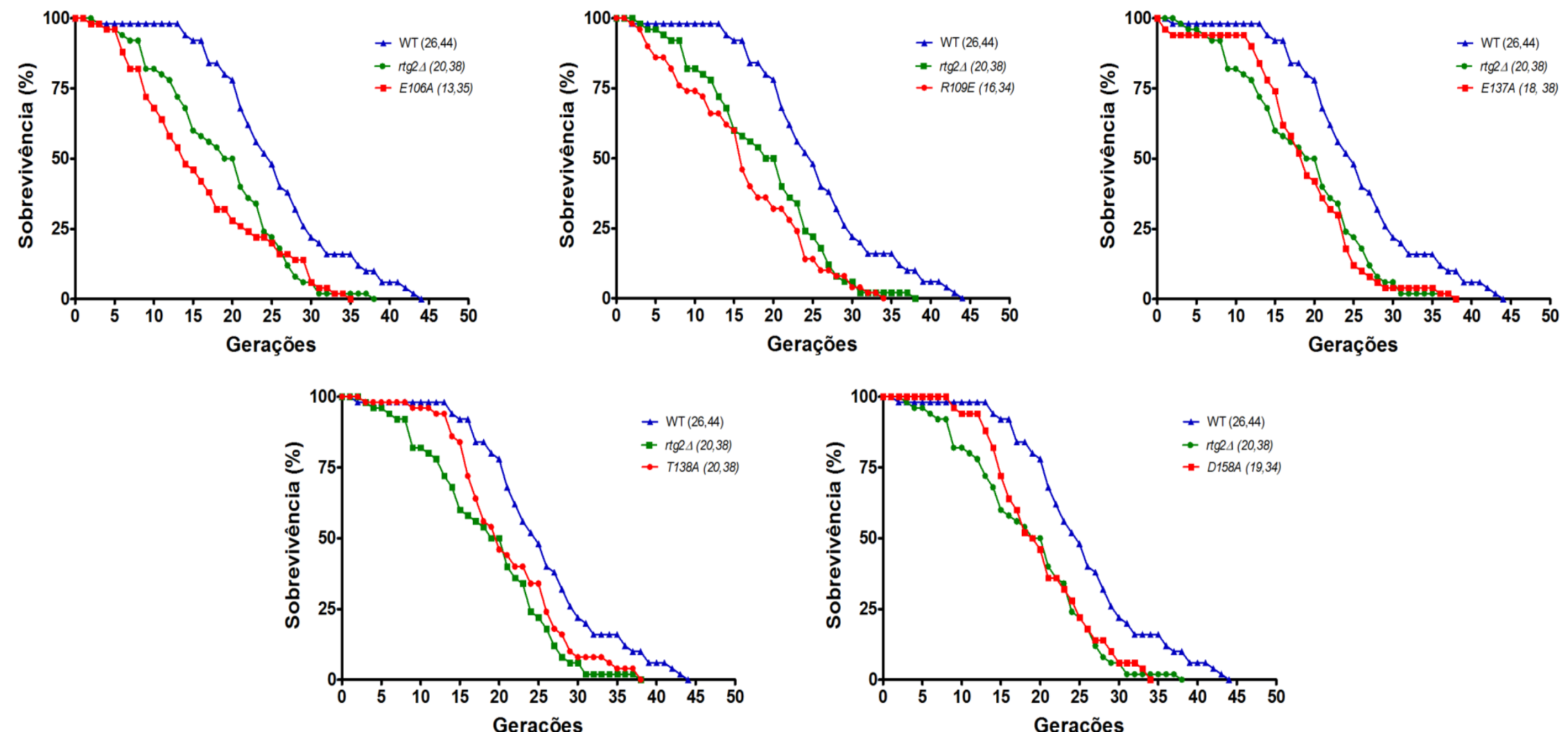

Figura 21 - Mutações pontuais comprometem longevidade replicativa da célula. Foram alinhadas 50 células de cada cepa em uma placa YPD, e as células-filhas foram removidas das mães para a construção da curva de sobrevivência. As longevidades média e máxima estão indicadas em parênteses (Média, Máxima). A significância estatística está indicada na tabela A1(Anexos). 

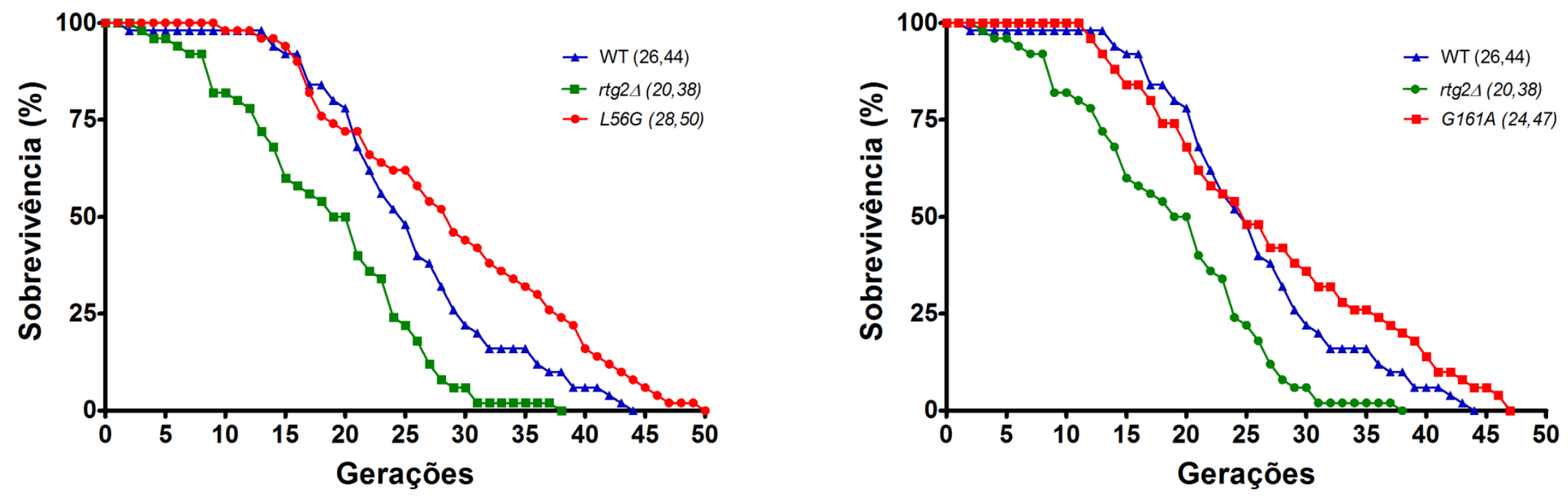

Figura 22 - Mutações pontuais aumentam longevidade replicativa da célula. Foram alinhadas 50 células de cada cepa em uma placa YPD, e as células-filhas foram removidas das mães para a construção da curva de sobrevivência. As longevidades média e máxima estão indicadas em parênteses (Média, Máxima). A significância estatística está indicada na tabela A1(Anexos). 
É possível observar uma diferença evidente entre a longevidade média e máxima das cepas WT e $r \operatorname{tg} 2 \Delta$ (Figura 19). Essas diferenças permitem comparar facilmente fenótipos de linhagens similares. Observando os gráficos de longevidade replicativa dos mutantes é possível dividi-los em três grupos; os similares ao WT, os similares ao $r \operatorname{tg} 2 \Delta$ e os longevos. Os mutantes E106H, N113A, A160G, S163A, Q165A e Q165E (Figura 20), possuem a longevidade replicativa média igual à da cepa WT ( $p<0,0001)$. Já os mutantes E106A, R109E, E137A, T138A e D158A (Figura 21), possuem a longevidade média igual à da cepa $r$ tg2 2 $(p<0,0001)$. Também podem-se destacar os mutantes $L 56 G$ e G161A (Figura 22), que apresentaram um longevidade média superior à da cepa WT, e esses formam um grupo dos mutantes longevos $(p<0,0001)$. 


\section{DISCUSSÃO}

A manutenção da função mitocondrial durante o crescimento e desenvolvimento das células se dá, em grande parte, a partir do genoma nuclear, que codifica maioria das proteínas mitocondriais, uma via de comunicação denominada resposta anterógrada. A outra parte dessa contribuição ocorre pelo genoma mitocondrial, o qual codifica um número limitado, mas essencial, de proteínas mitocondriais, representando a maioria dos componentes da via de fosforilação oxidativa (LIU; BUTOW, 2006).

Estudos exaustivos mostraram que as células respondem a mudanças no estado funcional das mitocôndrias, através de mudanças na expressão gênica nuclear, uma via de comunicação da mitocôndria para o núcleo, denominada resposta retrógrada, a qual engloba uma ampla variedade de atividades celulares, incluindo a detecção de nutrientes, controle do crescimento, envelhecimento e outros processos de sinalização que funcionam na homeostase metabólica e na manutenção da atividade mitocondrial (BUTOW; AVADHANI, 2004; LIU; BUTOW, 2006).

O processo geral de sinalização mitocondrial é conservado de eucariotos simples, tais como levedura, até os seres humanos. No entanto, os mecanismos moleculares de transmissão dos sinais parecem diferir entre os eucariotos simples dos eucariotos mais complexos, sendo bem caracterizados em $S$. cerevisiae. A primeira análise das consequências das disfunções mitocondriais foi realizada em 1987 quando foi observado o aumento da transcrição de diversos genes nucleares em cepas com deficiências respiratórias causadas por lesão no DNA mitocondrial. A partir desse estudo iniciou-se uma série de trabalhos para elucidar o mecanismo da sinalização retrógrada (BUTOW; AVADHANI, 2004; LIU; BUTOW, 2006; PARIKH et al., 1987).

Em S. cerevisiae, uma proteína de sinalização chave nesta via é Rtg2p, que desempenha um papel essencial na via retrógrada, sendo um sensor do estado funcional das mitocôndrias, necessária para a ativação da expressão dos genes RTG-dependentes, promovendo a translocação dos fatores de transcrição Rtg1p e Rtg3p do citoplasma para o núcleo (LIU; BUTOW, 2006; SEKITO; THORNTON; BUTOW, 2000). Além disso, Rtg2p é necessária para a desfosforilação parcial de Rtg3p associada com a sua acumulação nuclear (SEKITO; THORNTON; BUTOW, 2000). Como Rtg2p ainda não foi analisada a nível estrutural, o presente trabalho teve como objetivo identificar os determinantes estruturais de Rtg2p. 
Sabe-se que Rtg2p possui um domínio de ligação ao ATP em seu N-terminal, semelhante ao domínio da superfamília ASKHA actina/acetato e quinase de açúcar/hsp70 (ALVARADO et al., 2006; BORK; SANDER; VALENCIA, 1992; KOONIN, 1994). No alinhamento múltiplo de sequências de aminoácidos dessa superfamília, Rtg2p apresentou similaridade com sequências de exopolifosfatases (PPX) e guanosina pentafosfatases (GPPA) bacterianas, ambas as quais contêm os blocos de sequências conservadas envolvidas na ligação ao ATP (KOONIN, 1994).

Koonin (1994) mostrou um alinhamento das sequências de aminoácidos de GPPA, PPX de Escherichia coli e Rtg2p de Saccharomyces cerevisiae, obtido pelo programa MACAW, e revelou conservação de cinco motivos relacionado com regiões de ligação ao ATP denominados Phosphate 1, Phosphate 2, Connect 1, Connect 2, Adenosine (ALVARADO et al., 2006). A conservação dos principais motivos de sequências sugere que o núcleo estrutural da família também é conservado em Rtg2p, sendo possível identificar os resíduos da análise por DRCN posicionados nos cinco motivos identificado por Koonin (Figura 12).

Devido a essa homologia, todo o alinhamento obtido no PFAM da Família PF02541 constitui-se somente de proteínas que contêm esse domínio compartilhado, resultando em resíduos conservados somente nessa região (Figura 11), já que os outros domínios verificados em nosso modelo não possuem domínios associados no PFAM.

Dentre os resíduos de Rtg2p conservados, podemos destacar E137, D158 e Q165, que são conservados nas exopolifosfatases (PPX) de Escherichia coli (equivalentes em PPX: E121, D143, e E150). PPX é uma proteína que degrada longas cadeias de polifosfato inorgânico (ALVARADO et al., 2006). Mutações nesses resíduos em E. coli resultou na diminuição da atividade da exopolifosfatase, que manteve apenas uma atividade residual.

Em Rtg2p mostrou-se que mutações nesses resíduos também afetam suas funções, a mutação no resíduo D158 apresentou somente atividade residual de Rtg2p, por sua vez, o resíduo E137, quando mutado, apresentou atividade residual não só na resposta retrógrada e no envelhecimento, mas também no crescimento celular em meio mínimo, mesmo na presença de todos os nutrientes necessários. O mesmo resultado foi obtido quando mutou-se o resíduo Q165 para glutamato. Entretanto, quando alterou-se esse resíduo para alanina, manteve -se a expressão de CIT2 em $65,54 \%$ em comparação à cepa WT. Frente a isso, hipotetizou-se na tabela 9 que quando adiciona-se glutamato a essa região, esta se torna totalmente negativa e de alguma forma, causa uma mudança na polaridade, pois Rtg2p é o único membro da família que alterou a posição em um aminoácido não carregado 
(Glutamina). Provavelmente, ao longo do curso evolutivo isso favoreceu sua atividade, comprovando-se pelo fato de que quando alteramos o mesmo resíduo Q165 para alanina, um resíduo sem carga, a expressão de CIT2 é parcialmente restaurada, e a longevidade não é afetada. Isso indica que esses resíduos conservados na família possam participar da atividade de Rtg2p, assim como são responsáveis pelo sítio catalítico das Exopolifosfatase em E. coli.

Também é importante destacar que enquanto em Rtg2p o resíduo 165 é uma glutamina, na maioria dos membros da família é um glutamato. Esse mesmo resíduo em $E$. coli (E150) participa do sítio ativo das exopolifosfatases juntamente com um treonina 89, que em Rtg2p é uma treonina 105 na mesma posição. Portanto, estes resíduos são críticos para a ligação de fosfato e são comumente vistos nos membros da família ASKHA (ALVARADO et al., 2006). Considerando estes fatores, a alteração deste resíduo levou a baixa atividade de Rtg2p.

Além da conservação em E. coli o resíduo de Rtg2p D158, conservado em Aquifex aeolicus, corresponde a D141 e participa do sítio ativo da enzima exopolifosfatase (ALVARADO et al., 2006) o que corrobora mais com os nossos resultados, onde mutações nesse resíduo inativou Rtg2p.

A ligação e hidrólise do ATP dependem da presença de um íon $\mathrm{Mg}^{2+}$ e/ou $\mathrm{Mn}^{2+}$, ambos já localizados em outros membros da família ASKHA como, por exemplo, HSC70. Íons $\mathrm{Mg}^{2+}$ ligados ao solvente desempenham um papel crítico no sítio ativo de HSC70 atuando como um mediador na ligação ao ATP. Em hexoquinases, esta posição é quase sempre um aspartato, em HSC70 e actina correspondem a glutamato ou glutamina, sempre acompanhados por outros resíduos que auxiliam essa ligação (ALVARADO et al., 2006; HURLEY, 1996). Dado essa ligação do íon $\mathrm{Mg}^{2+}$ submeteu-se o modelo de Rtg2p ao servidor 3DLigandSite (www.sbg.bio.ic.ac.uk/3dligandsite/) e obtive-se as mesmas interações do ATP sendo estabilizado pelo $\mathrm{Mg}^{2+}$. Todavia, para que essa interação ocorra é necessário o auxílio de alguns resíduos, e, baseando-se nos resíduos conhecido da família, identificou-se dois prováveis resíduos que podem auxiliar nessa ligação, E137 e S163 (Figura 23). Uma vez que alteramos ambos para alanina, um resíduo bem menor que não favorece as pontes de hidrogênio com o $\mathrm{Mg}^{2+}$, há grande prejuízo para a resposta retrógrada (Figura 16). Zhang e colaboradores (2013) propuseram que a resposta retrógrada medeia a homeostase de ATP. Em baixos níveis de glutamato a sinalização é ativada para produção de $\alpha$-cetoglutarato e juntamente a isso há a produção de ATP. Quando o ATP está em níveis elevados, o mesmo se liga a Rtg2p e promove dissociação de Mks1p, que é fosforilado. Isso desliga a via retrograda e, por consequência a produção de ATP (ZHANG et al., 2013). Conhecendo-se os resíduos 
que facilitam essa estabilização do ATP em Rtg2p será possível testar a hipótese de que o ATP libera Mks1p do complexo com Rtg2p, em estudos futuros.

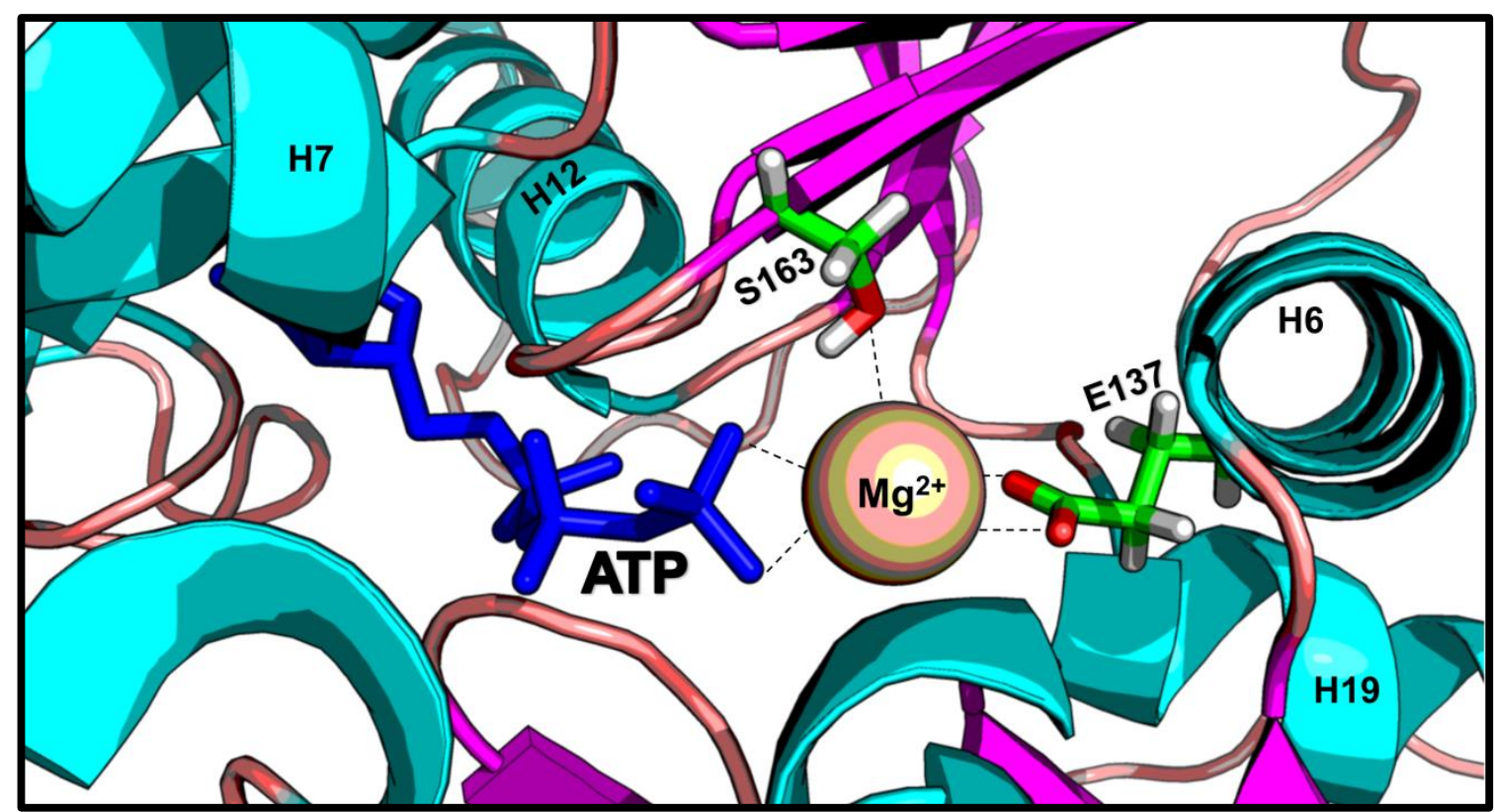

Figura 23 - Interação do ATP e $\mathrm{Mg}^{2+}$ no N-terminal de Rtg2p.

Através das cepas mutantes obtidas foi possível mapear resíduos determinantes nas funções exercidas por Rtg2p, nunca antes demonstradas na literatura. No momento em que as células estão com mitocôndrias comprometidas ou disfuncionais, há um aumento da expressão de um subconjunto de genes nucleares, pois Rtg2p permite que o fator de transcrição Rtg1/3p transcreva tais genes (CIT1, CIT2, ACO1, IDH1, e IDH2, genes que codificam as enzimas que catalisam as três primeiras etapas do ciclo do TCA que levam à produção de $\alpha$-cetoglutarato, o precursor direto de glutamato) (LIU; BUTOW, 1999). Sabe-se que o glutamato é um potente repressor da expressão do gene dependente da via RTG, sendo assim, células cultivadas na ausência desse aminoácido não conseguem crescer. Por conta disso, a sinalização retrograda detecta duas alterações na célula, a disfunção mitocondrial e os baixos níveis de glutamato. Na maioria das cepas mutantes produzidas, grande parte encontrou dificuldade em crescer na ausência de glutamato (Figura 16 e 17).

Entre os genes regulados por RTG2, podemos destacar CIT2 que tem sua expressão totalmente dependente dos genes RTG (RTG1, RTG2 e RTG3). Por isso, a ativação transcricional deste gene tornou-se um diagnóstico para estudos da resposta retrograda. Nas linhagens utilizadas no presente trabalho, CIT2-LacZ está integrado no genoma (LIAO et al., 1991). Uma característica de CIT2 é aumento da sua expressão em células crescidas em meio mínimo na ausência de glutamato (BUTOW; AVADHANI, 2004; LIAO et al., 1991; LIU; 
BUTOW, 1999, 2006). Em 2003, Liu e colaboradores, mostraram que mutantes de Rtg2p dentro das regiões phosphate 2 (G154D), adenosine (G226V) e connect 2 (G311D) apresentavam redução na expressão do gene repórter CIT2 e na capacidade de Rtg2p se ligar a Mks1p (LIU et al., 2003). Nossas mutações pontuais em sua grande maioria, inibiram a expressão da $\beta$-galactosidase, assim como os mutantes dentro das regiões phosphate 2 e connect 1 com exceção de G161A e Q165A; todos os outros tiveram a expressão similar a da cepa $\operatorname{rtg} 2 \Delta$ (Figura 18). Em concordância com o trabalho de Liu e colaboradores (2003), observamos que esse domínio é muito importante para o desempenho da função de Rtg2p na sinalização retrógrada.

Outra relação intrigante de Rtg2p é com o envelhecimento, uma vez que no trabalho de Kirchman e colaboradores (1999), células com o gene RTG2 rompido tinham a longevidade menor em comparação a cepas selvagens, assim como observado em nosso ensaio (Figura 19), demostrando que a função mitocondrial e o envelhecimento são correlacionados, podendo exercer um papel importante na longevidade da levedura (BORGHOUTS et al., 2004; JIANG et al., 2000; KIRCHMAN et al., 1999). Mesmo alterando apenas um único aminoácido da proteína Rtg2p em nossos mutantes, foi possível identificar um conjunto de aminoácidos que quando alterados influenciam na longevidade das células.

Sob um olhar perspectivo, quando transportam-se os resultados obtidos através das mutações para o modelo tridimensional de Rtg2p, é possível perceber que a distribuição dos resíduos de acordo com a longevidade replicativa subdivide o N-terminal de Rtg2p em três regiões distintas (Figura 24): na primeira localizam-se os resíduos que mesmo alterados não causaram perturbações severas na longevidade $(E 106 H, N 113 A, A 160 G, S 163 A, Q 165 A e$ $Q 165 E)$; na segunda estão os resíduos que em todos os ensaio tiveram semelhança com a cepa $\operatorname{rtg} 2 \Delta$ (E106A, R109E, E137A, T138A e D158A) e, na terceira região localizam-se as mutações que proporcionaram uma longevidade aumentada (L56G e G161A). Essa distribuição espacial para esses resíduos mostra que, aparentemente, a atuação de Rtg2p na longevidade reside em uma parte específica do N-terminal (BARROS et al., 2004; JAZWINSKI, 2005). 


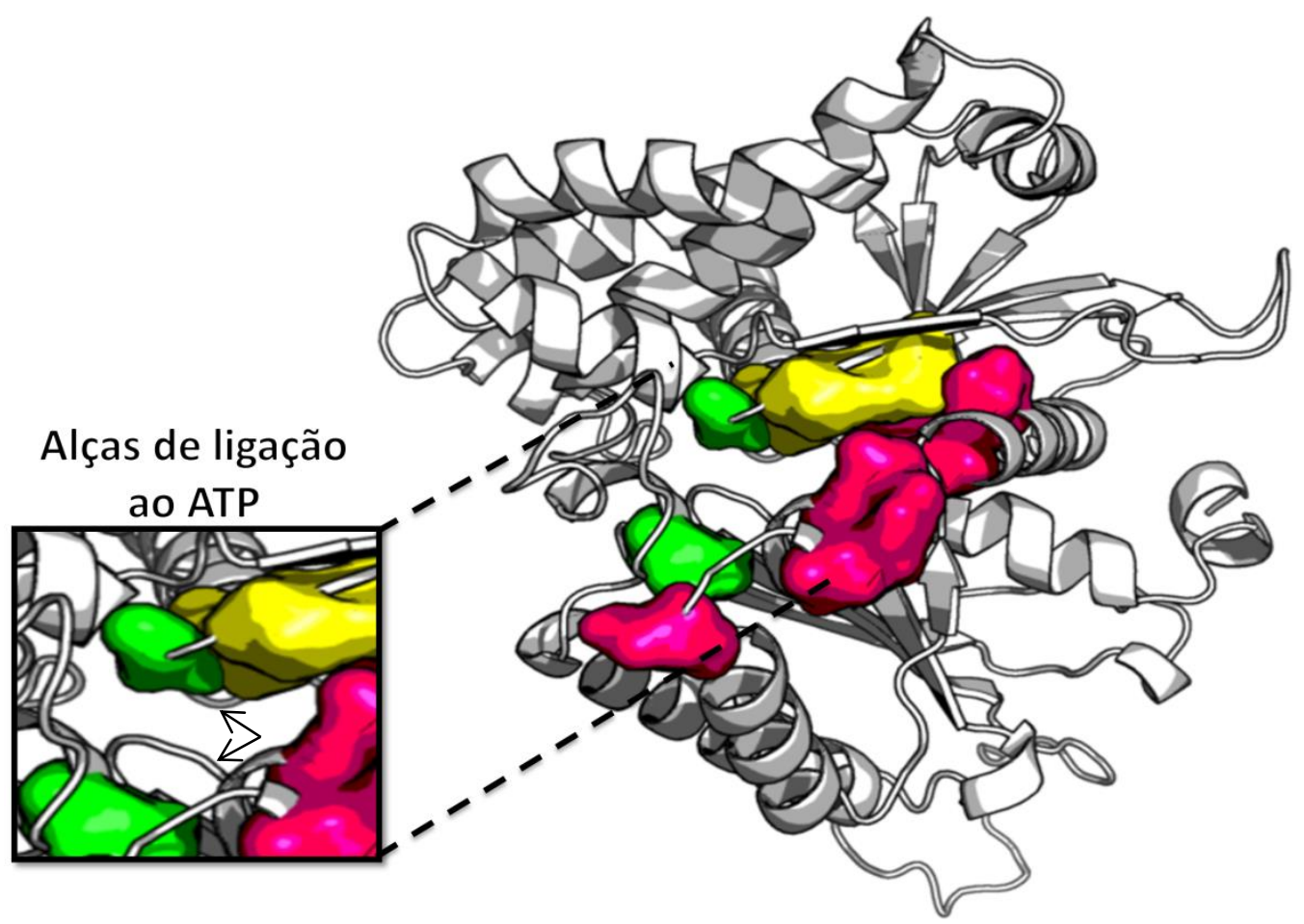

Figura 24 - Resíduos do N-terminal de Rtg2p dividos em três regiões distintas. Em amarelo os resíduos que não alteram a longevidade, em rosa os resíduos que possuem longevidade similar a cepa $r \operatorname{tg} 2 \Delta$ e em verde resíduos que mutados estendem a longevidade da cepa, com alças de ligação ao ATP indicado.

A relação de Rtg2p com o envelhecimento ainda não está totalmente elucidada, contudo, é sabido que uma das atuações de Rtg2p na longevidade de S. cerevisiae parece residir na associação ao complexo SAGA, formando o complexo SLIK. Esse complexo domina a transcrição de $10 \%$ do genoma de S. cerevisiae, e está envolvido na indução de genes envolvidos na resposta ao estresse (HUISINGA; PUGH, 2004). A presença de Rtg2p em SLIK expande o repertório coativador do mesmo, incluindo a transcrição de genes metabólicos que são ativados na resposta retrógrada. Desta forma, entende-se que a resposta retrógrada pode ser considerada uma resposta ao estresse. Acredita-se que o mecanismo de modulação de SLIK é iniciado com Rtg2p monitorando o estado metabólico das mitocôndrias. Na presença da disfunção mitocondrial, Rtg2p auxilia na translocação do complexo de fatores de transcrição Rtg1/3p para o núcleo. Em seguida, Rtg2p se associaria ao complexo SAGA, formando o complexo SLIK, para coativar a expressão de genes que respondem à sinalização retrógrada. Estes genes codificam proteínas envolvidas no metabolismo e na resistência ao estresse ( JAZWINSKI, 2005; PRAY-GRANT et al., 2002).

Quer sozinho ou em complexo com outras proteínas, Rtg2p participa de processos que são distintos da sinalização retrógrada, tais como, supressão de expansão trinucleotídeos, estabilidade genômica e acidificação vacuolar. 
Estudos indicaram a participação de Rtg2p na supressão da expansão de tripletos CTG •GAC que ocorre no DNA nuclear em células de levedura e mamífero e levam a instabilidade genômica. Em mamífero a expansão dos tripletos é uma das causas da doença de Huntington, uma doença neurodegenerativa que leva à degeneração dos neuronal. Não se sabe exatamente como $\operatorname{Rtg} 2 p$ atua nesta expansão, porém, evidencias indicam que $R T G 2$ está envolvido na supressão dos tripletos através de uma via nova, distinta da resposta retrógrada,

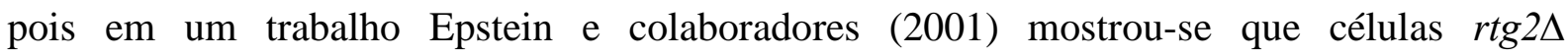
apresentavam expressão alterada de alguns genes que influenciam na instabilidade genômica (BHATTACHARYYA et al., 2002).

Rtg2p também está envolvida na acidificação do vacúolo de células com deficiência de cardiolipina (CHEN et al., 2008). Cardiolipina é um fosfolipídio aniônico predominantemente localizada na membrana mitocondrial interna e está relacionado com a função mitocondrial, biogênese, e a estabilidade do genoma (DAUM; GRAZ, 1985; GREENBERG, 2000; JIANG et al., 2000; SCHLAME; RUA; ZHONG et al., 2004). Em estudos, demonstrou-se que as células de levedura mutantes na cardiolipina sintase, codificada pelo gene $C R D 1$, exibem a formação de colônias com defeito morfológico, quando crescidas em temperatura elevada mesmo em meio com glicose, e também apresentam mitocôndrias com potencial de membrana reduzido, perturbação no acoplamento e instabilidade da cadeia de transporte de elétrons. Chen e colaboradores (2008), demonstraram que o defeito de crescimento em altas temperatura causava uma biogénese anormal e/ou acidificação do vacúolo, então especularam que o mecanismo de defeitos vacuolares em resposta à diminuição da cardiolipina, poderia estar associado com alguns aspectos da função mitocondrial. Para testar essa hipótese deletaram RTG2 a fim de verificar se havia uma comunicação entre a mitocôndria e o vacúolo. A deleção de $R T G 2$ melhorou o fenótipo de deficiência em cardiolipina, sugerindo fortemente que Rtg2p pode mediar à resposta vacuolar à deficiência de cardiolipina, por um mecanismo que parece ser independente da regulação retrógrada. Estudos anteriores demonstraram que as funções do vacúolo por serem altamente conservadas durante a evolução, podem modular a função mitocondrial e também podem modular tempo de vida das leveduras, atuando diretamente sobre o envelhecimento (HUGHES; GOTTSCHLING, 2012).

Rtg2p também suprime a produção de círculos extracromossomais (ERCs) de rDNA. Não se sabe o mecanismo, porém sabe-se que os ERCs são uma forma de instabilidade do genoma, que se acumula ao longo do envelhecimento das leveduras e, quando presente em altos níveis, diminuem a longevidade das células (PARK; DEFOSSEZ; GUARENTE, 1999). 
Entretanto, a supressão de ERCs por Rtg2p somente ocorre quando a mesma não está participando do processo de transmissão da sinalização retrógrada; isso foi comprovado a partir de células sem DNA mitocondrial, pois estas acumulavam mais ERCs, confirmando que Rtg2p participa exclusivamente da sinalização retrograda nessas condições (BORGHOUTS et al., 2004).

Os trabalhos supracitados $R \operatorname{tg} 2 p$ indicam que Rtg2p é muito importante na longevidade de S. cerevisiae, participando, inclusive, de outras vias distintas da sinalização retrógrada. No presente trabalho foi possível que a região $\mathrm{N}$-terminal Rtg2p é muito importante para suas diversas funções, e a coleção de mutantes produzidos por este trabalho permitirá o estudo estrutural do mecanismo molecular de atuação de Rtg2p nos processos próenvelhecimento que incluem expansão de repetições de tripletos, instabilidade genômica e comunicação entre mitocôndria e vacúolo. 


\section{CONCLUSÕES FINAIS}

- Em sua grande maioria, os resíduos indicados pelas análises do DRCN causaram alguma perturbação nas funções de Rtg2p.

- Muitos dos resíduos identificados pela análise de DRCN estão relacionados diretamente aos motivos de ligação ao ATP indicados por Koonin, com destaque aos resíduos E137 e S163, que em nosso modelo estabilizam o ATP juntamente com o $\mathrm{Mg}^{2+}$.

- A análise DRCN permitiu identificar resíduos importantes para a sinalização retrógrada:

○ As cepas com mutações $N 113 A$ e $Q 165 A$ não causaram perturbações severas na sinalização retrograda, uma vez que não apresentaram auxotrofia para glutamato e não tiveram a expressão de CIT2 totalmente reprimida.

○ O N-terminal da proteína se mostrou muito importante para a sinalização retrógrada, assim como demonstrado em trabalhos anteriores.

- Análise de DRCN permitiu mapear o N-terminal de Rtg2p e entender qual a região importante para sua atuação na longevidade. Foi possível entender que o N-terminal possui um subdomínio muito importante na longevidade e outros subdomínios que mesmo mutados não influenciam na longevidade de Rtg2p.

- A partir dessa descoberta será possível entender outras funções de Rtg2p no envelhecimento, utilizando a coleção de mutantes produzidos pelo presente estudo. 


\section{REFERÊNCIAS*}

ALVARADO, J.; GHOSH, A.; JANOVITZ, T.; JAUREGUI, A.; HASSON, M. S.; SANDERS, D. A. Origin of Exopolyphosphatase Processivity: Fusion of an ASKHA Phosphotransferase and a Cyclic Nucleotide Phosphodiesterase Homolog. Structure, v. 14, n. 8, p. 1263-1272, 2006.

ANDERSSON, G. E.; KARLBERG, O.; CANBACK, B.; KURLAND, C. G. On the origin of mitochondria: a genomics perspective. Philosophical Transactions of the Royal Society B: Biological Sciences, v. 358, n. 1429, p. 165-179, 2003.

ARNOLD, K.; BORDOLI, L.; KOPP, J.; SCHWEDE, T. The SWISS-MODEL workspace: a web-based environment for protein structure homology modelling. Bioinformatics, v. 22, n. 2, p. 195-201, 2006.

ATChley, W. R.; TERHAlle, W.; DRESS, A. Positional Dependence, Cliques, and Predictive Motifs in the bHLH Protein Domain. Journal of Molecular Evolution, v. 48, n. 5, p. 501-516, maio 1999.

BACHEGA, J. F. R.; NAVARRO, M.; BLEICHER, L.; BORTOLETO-BUGS, R. K.; DIVE, D.; HOFFMANN, P.; VISCOGLIOSI, E.; GARRATT, R. C. Systematic structural studies of iron superoxide dismutases from human parasites and a statistical coupling analysis of metal binding specificity. Proteins-Structure Function and Bioinformatics, v. 77, n. 1, p. 26-37, 2009.

BARROS, M. H.; BANDY, B.; TAHARA, E. B.; KOWALTOWSKI, A. J. Higher respiratory activity decreases mitochondrial reactive oxygen release and increases life span in Saccharomyces cerevisiae. Journal of Biological Chemistry, v. 279, n. 48, p. 49883-49888, 2004.

BARTON, A. A. Some aspects of cell division in saccharomyces cerevisiae. Journal of general microbiology, v. 4, n. 1, p. 84-86, 1950.

BHATTACHARYYA, S.; ROLFSMEIER, M. L.; DIXON, M. J.; WAGONER, K.; LAHUE, R. S. Identification of RTG2 as a modifier gene for $\mathrm{CTG}^{*} \mathrm{CAG}$ repeat instability in Saccharomyces cerevisiae. Genetics, v. 162, n. 2, p. 579-589, 2002.

BLEICHER, L.; LEMKE, N.; GARRATT, R. C. Using Amino Acid Correlation and Community Detection Algorithms to Identify Functional Determinants in Protein Families. PLoS ONE, v. 6, n. 12, p. e27786, 2011. 
BORGHOUTS, C.; BENGURIA, A.; WAWRYN, J.; JAZWINSKI, S. M. Rtg2 Protein Links Metabolism and Genome Stability in Yeast Longevity. Genetics, v. 166, n. 2, p. 765-777, 2004.

BORK, P.; SANDER, C.; VALENCIA, a. An ATPase domain common to prokaryotic cell cycle proteins, sugar kinases, actin, and hsp70 heat shock proteins. Proceedings of the National Academy of Sciences of the United States of America, v. 89, n. 16, p. 7290-7294, 1992.

BRAUN, E. L.; FUGE, E. K.; PADILLA, P. a; WERNER-WASHBURNE, M. A stationaryphase gene in Saccharomyces cerevisiae is a member of a novel, highly conserved gene family. Journal of Bacteriology, v. 178, n. 23, p. 6865-6872, 1996.

BUSSO, C.; TAHARA, E. B.; OGUSUCU, R.; AUGUSTO, O.; FERREIRA-JUNIOR, J. R.; TZAGOlOFF, A.; KOWALTOWSKI, A. J.; BARROS, M. H. Saccharomyces cerevisiae coq10 null mutants are responsive to antimycin A. Federation of European Biochemical Societies Journal v. 277, p. 4530-4538, 2010.

BUTOW, R. A.; AVADHANI, N. G. Mitochondrial SignalingThe Retrograde Response. Molecular Cell, v. 14, n. 1, p. 1-15, 2004.

CHEN, S.; TARSIO, M.; KANE, P. M.; GREENBERG, M. L. Cardiolipin Mediates CrossTalk between Mitochondria and the Vacuole. Molecular Biology of the Cell, v. 19, n. 12, p. 5047-5058, 1 dez. 2008.

DAUM, G.; GRAZ, T. U. Lipids of mitochondria. Institut fur Biochemie and lebensmittelchemie, v. 822, p. 1-42, 1985.

DEKKER, J. P.; FODOR, A.; ALDRICH, R. W.; YELLEN, G. A perturbation-based method for calculating explicit likelihood of evolutionary co-variance in multiple sequence alignments. Bioinformatics, v. 20, n. 10, p. 1565-1572, 2004.

DELANO, W. L. Unraveling hot spots in binding interfaces: progress and challenges. Current opinion in structural biology, v. 12, n. 1, p. 14-20, fev. 2002.

DILOVA, I.; CHEN, C. Y.; POWERS, T. Mks1 in concert with TOR signaling negatively regulates RTG target gene expression in S. cerevisiae. Current Biology, v. 12, n. 5, p. 389$395,2002$.

DUINA, A. A.; MILLER, M. E.; KEENEY, J. B. Budding Yeast for Budding Geneticists: A Primer on the Saccharomyces cerevisiae Model System. Genetics, v. 197, n. 1, p. 33-48, 2014.

EPSTEIN, C. B.; WADDLE, J. a; HALE, W.; DAVÉ, V.; THORNTON, J.; MACATEE, T. L.; GARNER, H. R.; BUTOW, R. a. Genome-wide responses to mitochondrial dysfunction. Molecular biology of the cell, v. 12, n. 2, p. 297-308, 2001.

ERJAVEC, N.; LARSSON, L.; GRANTHAM, J.; NYSTRÖM, T. Accelerated aging and failure to segregate damaged proteins in Sir2 mutants can be suppressed by overproducing the 
protein aggregation-remodeling factor Hsp104p. Genes \& Development. p. 2410-2421, 2007.

FABRIZIO, P.; LONGO, V. D. The chronological life span of Saccharomyces cerevisiae. Methods in Molecular Biology. p. 73-81, 2003.

FELDMANN, H. Yeast. Weinheim, Germany: Wiley-VCH Verlag GmbH \& Co. KGaA, 2012. 464p.

FERREIRA, J. R.; SPÍREK, M.; LIU, Z.; BUTOW, R. a. Interaction between Rtg2p and Mks1p in the regulation of the RTG pathway of Saccharomyces cerevisiae. Gene, v. 354, n. 1-2 SPEC. ISS., p. 2-8, 18 jul. 2005.

FERREIRA-JÚNIOR, J. R.; BLEICHER, L.; BARROS, M. H. Her2p molecular modeling , mutant analysis and intramitochondrial localization. Fungal Genetics and Biology, v. 60, p. 133-139, 2013.

FERREIRA-JÚNIOR, R.; PAULELA, J. A.; BUSSO, C.; BLEICHER, L.; DEMASI, M.; BARROS, M. H. Coq7p relevant residues for protein activity and stability. Biochimie. v. 119, p. 92-102, 2015.

FLAKE, G. W.; LAWRENCE, S.; LEE GILES, C.; COETZEE, F. M. Self-organization and identification of web communities. Computer, v. 35, n. 3, p. 66-71, 2002.

FLATT, T.; SCHMIDT, P. S. Integrating evolutionary and molecular genetics of aging. Biochimica et Biophysica Acta (BBA) - General Subjects, v. 1790, n. 10, p. 951-962, out. 2009.

FORSBERG, H.; GILSTRING, C. F.; ZARGARI, A.; MARTI, P. The role of the yeast plasma membrane SPS nutrient sensor in the metabolic response to extracellular amino acids. Molecular Microbiology, v. 42, p. 215-228, 2001.

GERSHON, H.; GERSHON, D. The budding yeast, Saccharomyces cerevisiae, as a model for aging research: a critical review. Mechanism of aging and development, v. 120, n. 1-3, p. 122, 2000.

GIETZ, R. D. Yeast Transformation by the LiAc/SS Carrier DNA/PEG Method. Methods in Molecular Biology, p.107-119 2006.

GIETZ, R. DANIEL AND SUGINO, A. New yeast - Escherichia coli shuttle vectors constructed with in vitro mutagenized yeast genes lacking six-base pair restiction sites. Gene, v. 74, p. 527-534, 1988.

GLAB, N.; PETIT, P. X.; SLONIMSKI, P. P. Mitochondrial dysfunction in yeast expressing the cytoplasmic male sterility T-urf13 gene from maize: analysis at the population and individual cell level. Molecular \& general genetics : MGG, v. 236, n. 2-3, p. 299-308, 1993..

GÖBEL, U.; SANDER, C.; SCHNEIDER, R.; VALENCIA, A. Correlated mutations and 
residue contacts in proteins. Proteins: Structure, Function, and Genetics, v. 18, n. 4, p. 309-317, abr. 1994.

GOFFEAU, A.; BARRELL, B. G.; BUSSEY, H.; DAVIS, R. W.; DUJON, B.; FELDMANN, H.; GALIBERT, F.; HOHEISEL, J. D.; JACQ, C.; JOHNSTON, M.; LOUIS, E. J.; MEWES, H. W.; MURAKAMI, Y.; PHILIPPSEN, P.; TETTELIN, H.; OLIVER, S. G. Life with 6000 Genes conveniently among the different interna- Old Questions and New Answers The genome. At the beginning of the se- of its more complex relatives in the eukary- cerevisiae has been completely sequenced Schizosaccharomyces pombe indicate. Science, v. 274, n. October, p. 546-567, 1996.

GUARAGNELLA, N.; BUTOW, R. a. ATO3 encoding a putative outward ammonium transporter is an RTG-independent retrograde responsive gene regulated by GCN4 and the Ssy1-Ptr3-Ssy5 amino acid sensor system. The Journal of biological chemistry, v. 278, n. 46, p. 45882-45887, 2003.

HALABI, N.; RIVOIRE, O.; LEIBLER, S.; RANGANATHAN, R. Protein sectors: evolutionary units of three-dimensional structure. Cell, v. 138, n. 4, p. 774-86, 2009.

HANAHAN, D. Studies on transformation of Escherichia coli with plasmids. Journal of molecular biology, v. 166, n. 4, p. 557-580, 1983.

HECKMAN, K. L.; PEASE, L. R. Gene splicing and mutagenesis by PCR-driven overlap extension. Nature Protocols, v. 2, n. 4, p. 924-932, 2007.

HUGHES, A. L.; GOTTSCHLING, D. E. An early age increase in vacuolar pH limits mitochondrial function and lifespan in yeast. Nature, v. 492, n. 7428, p. 261-265, 2012.

HUISINGA, K. L.; PUGH, B. F. A Genome-Wide Housekeeping Role for TFIID and a Highly Regulated Stress-Related Role for SAGA in Saccharomyces cerevisiae. Molecular Cell, v. 13, n. pol II, p. 573-585, 2004.

HURLEY, J. H. THE SUGAR KINASE / HEAT SHOCK PROTEIN 70 / ACTIN SUPERFAMILY : Implications of Conserved Structure for Mechanism. Annual Review of Biophysics and Biomolecular Structure, 1996.

JANKE, C.; MAGIERA, M. M.; RATHFELDER, N.; TAXIS, C.; REBER, S.; MAEKAWA, H.; MORENO-BORCHART, A.; DOENGES, G.; SCHWOB, E.; SCHIEBEL, E.; KNOP, M. A versatile toolbox for PCR-based tagging of yeast genes: new fluorescent proteins, more markers and promoter substitution cassettes. Yeast, v. 21, n. 11, p. 947-962, 2004.

JAZWINSKI, S. M. Longevity, Genes, and Aging. Science, v. 273, n. 5271, p. 54-59, 1996.

JAZWINSKI, S. M. Rtg2 protein: At the nexus of yeast longevity and aging. FEMS Yeast Research, v. 5, n. 12, p. 1253-1259, 2005.

JIA, Y.; ROTHERMEL, B.; THORNTON, J.; BUTOW, R. A. A basic helix-loop-helixleucine zipper transcription complex in yeast functions in a signaling pathway from mitochondria to the nucleus. Molecular and cellular biology, v. 17, n. 3, p. 1110-7, 1997. 
JIANG, F.; RYAN, M. T.; SCHLAME, M.; ZHAO, M.; GU, Z.; KLINGENBERG, M.; PFANNER, N.; GREENBERG, M. L. Absence of Cardiolipin in the crd1 Null Mutant Results in Decreased Mitochondrial Membrane Potential and Reduced Mitochondrial Function. Journal of Biological Chemistry, v. 275, n. 29, p. 22387-22394, 21 jul. 2000.

KAEBERLEIN, M. Lessons on longevity from budding yeast. Nature, v. 464, n. 7288, p. 513-519, 2010.

KAEBERLEIN, M.; MCVEY, M.; GUARENTE, L. The SIR2/3/4 complex and SIR2 alone promote longevity in Saccharomyces cerevisiae by two different mechanisms. Genes \& development, v. 13, n. 19, p. 2570-2580, 1 out. 1999.

KELLEY, L. a; STERNBERG, M. J. E. Protein structure prediction on the Web: a case study using the Phyre server. Nature protocols, v. 4, n. 3, p. 363-371, jan. 2009.

KELlEY, L. A.; MEZULIS, S.; YATES, C. M.; WASS, M. N.; STERNBERG, M. J. E. The Phyre 2 web portal for protein modeling, prediction and analysis. Nature Protocols, v. 10, n. 6, p. 845-858, 2015.

KIM, D. E.; CHIVIAN, D.; BAKER, D. Protein structure prediction and analysis using the Robetta server. Nucleic Acids Research, v. 32, n. Web Server, p. W526-W531, 2004.

KIM, S.; OHKUNI, K.; COUPLAN, E.; JAZWINSKI, S. M. The histone acetyltransferase GCN5 modulates the retrograde response and genome stability determining yeast longevity. Biogerontology, v. 5, n. 5, p. 305-16, 2004.

KIRCHMAN, P. a.; KIM, S.; LAI, C. Y.; MICHAL JAZWINSKI, S. Interorganelle signaling is a determinant of longevity in Saccharomyces cerevisiae. Genetics, v. 152, n. 1, p. 179-190, 1999.

KOONIN, E. PROTEIN SEQUENCE Yeast protein controlling communication is related to bacterial phosphatases PROTEIN SEQUENCE A specific amino acid repeat in squalene and. Elsevier Science, p. 70-71, 1994.

KRUEGEL, U.; ROBISON, B.; DANGE, T.; KAHLERT, G.; DELANEY, J. R.; KOTIREDDY, S.; TSUCHIYA, M.; TSUCHIYAMA, S.; MURAKAMI, C. J.; SCHLEIT, J.; SUTPHIN, G.; CARR, D.; TAR, K.; DITTMAR, G.; KAEBERLEIN, M.; KENNEDY, B. K.; SCHMIDT, M. Elevated Proteasome Capacity Extends Replicative Lifespan in Saccharomyces cerevisiae. PLoS Genetics, v. 7, n. 9, p. e1002253, 2011.

LAMBERT, C.; LÉONARD, N.; DE BOLLE, X.; DEPIEREUX, E. ESyPred3D: Prediction of proteins 3D structures. Bioinformatics, v. 18, n. 9, p. 1250-1256, 2002.

LIAO, X.; BUTOW, R. A. R7' G1 and RTGZ: Two Yeast Genes Requbd for a Novel Path of Commnicrdlan from Cndria to the Nudeus. Cell Press, v. 72, p. 61-71, 1993.

LIAO, X. S.; SMALL, W. C.; SRERE, P. A.; BUTOW, R. A. Intramitochondrial functions regulate nonmitochondrial citrate synthase (CIT2) expression in Saccharomyces cerevisiae. Molecular and cellular biology, v. 11, n. 1, p. 38-46, 1991. 
LIU, Z:; BUTOW, R. a. A Transcriptional Switch in the Expression of Yeast Tricarboxylic Acid Cycle Genes in Response to a Reduction or Loss of Respiratory Function $\uparrow$. Molecular and Cellular Biology, v. 19, n. 10, p. 6720-6728, 1999.

LIU, Z.; BUTOW, R. a. Mitochondrial retrograde signaling. Annual review of genetics, v. 40, p. 159-185, jan. 2006.

LIU, Z.; SEKITO, T.; EPSTEIN, C. B.; BUTOW, R. A. RTG-dependent mitochondria to nucleus signaling is negatively regulated by the seven WD-repeat protein Lst8p. The EMBO journal, v. 20, n. 24, p. 7209-7219, 2001.

LIU, Z.; SEKITO, T.; ŠPÍREK, M.; THORNTON, J.; BUTOW, R. a. Retrograde signaling is regulated by the dynamic interaction between Rtg2p and Mks1p. Molecular Cell, v. 12, p. 401-411, 2003.

LOCKLESS, S. W.; RANGANATHAN, R.; KUKIC, P.; MIRABELLO, C.; TRADIGO, G.; WALSH, I.; VELTRI, P.; POLLASTRI, G.; SOCOLICH, M.; LOCKLESS, S. W.; RUSS, W. P.; LEE, H.; GARDNER, K. H.; RANGANATHAN, R.; KRETH, K. E.; FODOR, A. a; BALAKRISHNAN, S.; KAMISETTY, H.; CARBONELL, J. G.; LEE, S.-I.; LANGMEAD, C. J.; THORNTON, J. M.; ORENGO, C. a; TODD, a E.; PEARL, F. M. Evolutionarily conserved pathways of energetic connectivity in protein families. BMC Bioinformatics, v. 15, n. 5438, p. 295-299, 1999.

LONGO, V. D.; FABRIZIO, P. Chronological Aging in Saccharomyces cerevisiae. In: BREITENBACH, M.; JAZWINSKI, S. M.; LAUN, P. Subcell Biochem. Subcellular Biochemistry. Dordrecht: Springer Netherlands, 2011. p. 101-121.

LONGO, V. D.; GRAllA, E. B.; VAlENTINE, J. S. Superoxide Dismutase Activity Is Essential for Stationary Phase Survival in Saccharomyces cerevisiae. Journal of Biological Chemistry. v. 271, n. 21, p. 12275-12280, 1996.

LÜTHY, R.; BOWIE, J. U.; EISENBERG, D. Assessment of protein models with threedimensional profiles. Nature, v. 356, n. 6364, p. 83-85, 1992.

MARGULIS, L. This Week's Citation Classic. Symbiosis in cell evolution, v. 9, n. 1981, p. $1958,1980$.

MCCLEARN, G. E. Biomarkers of age aging. Experimental Gerontology, v. 32, p. 87-94, 1997.

MEDVEDEV, Z. A.; IAA, L. N. W. An attempt at a rational classification of theories of ageing. Biology, v. 65, p. 375-398, 1990.

MOLIN, M.; YANG, J.; HANZÉN, S.; TOLEDANO, M. B.; LABARRE, J.; NYSTRÖM, T. Life Span Extension and $\mathrm{H} 2 \mathrm{O} 2$ Resistance Elicited by Caloric Restriction Require the Peroxiredoxin Tsal in Saccharomyces cerevisiae. Molecular Cell, v. 43, n. 5, p. 823-833, set. 2011.

MORTIMER, R. K.; JOHNSTON, J. R. Life Span of Individual Yeast Cells. Nature, v. 183, 
n. 4677 , p. 1751-1752, 1959.

NEWMAN, M. E. J.; GIRVAN, M. Finding and evaluating community structure in networks. Physical Review, v. 69, n. 2, p. 026113, 2004.

NICHOLLS, D ; LOCKE, R. ' Reviews in Brown Fat. Physiological reviews, v. 64, p. 3-64, 1984.

PARIKH, V. S.; MORGAN, M. M.; SCOTT, R.; CLEMENTS, L. S.; BUTOW, R. a. The mitochondrial genotype can influence nuclear gene expression in yeast. Science, v. 235, n. 4788, p. 576-80, 1987.

PARK, B. P. U.; MCVEY, M.; GUARENTE, L. Separation of mother ans daughter cells. Methods in Enzymology. v. 351, n. 1959, p. 468-477, 2002.

PARK, P. U.; DEFOSSEZ, P.-A.; GUARENTE, L. Effects of Mutations in DNA Repair Genes on Formation of Ribosomal DNA Circles and Life Span in Saccharomyces cerevisiae. Molecular and Cellular Biology, v. 19, n. 5, p. 3848-3856, 16 maio 1999.

PETRANOVIC, D.; NIELSEN, J. Can yeast systems biology contribute to the understanding of human disease? Trends in Biotechnology, v. 26, n. 11, p. 584-590, 2008.

PRAY-GRANT, M. G.; SCHIELTZ, D.; MCMAHON, S. J.; WOOD, J. M.; KENNEDY, E. L.; COOK, R. G.; WORKMAN, J. L.; YATES, J. R.; GRANT, P. A. The novel SLIK histone acetyltransferase complex functions in the yeast retrograde response pathway. Molecular and cellular biology, v. 22, n. 24, p. 8774-8786, 2002.

RADFORD, A. Methods in yeast genetics - a laboratory course manual. Cold Spring Harbor Laboratory Press, 1991. v. 19. p. 198.

RADICCHI, F.; CASTELLANO, C.; CECCONI, F.; LORETO, V.; PARISI, D. Defining and identifying communities in networks. Proceedings of the National Academy of Sciences of the United States of America, v. 101, n. 9, p. 2658-2663, 2004.

ROTHERMEL, B. A.; THORNTON, J. L.; BUTOW, R. A. Rtg3p, a basic helix-loophelix/leucine zipper protein that functions in mitochondrial-induced changes in gene expression, contains independent activation domains. Journal of Biological Chemistry, v. 272, n. 32, p. 19801-19807, 1997.

SAMBROOK, J.; FRITSCH, E. F.; MANIATIS, T. Molecular cloning: a laboratory manual. Cold Spring Harbor Laboratory Press, 1989. v. p.2222.

SCHLAME, M.; RUA, D.; GREENBERG, M. L. The biosynthesis and functional role of cardiolipin. Progress in lipid research, v. 39, p. 257-288, 2000.

SCHÖNEICH, C. Reactive oxygen species and biological aging: A mechanistic approach. Experimental Gerontology, v. 34, n. 1, p. 19-34, 1999.

SEKITO, T.; LIU, Z.; THORNTON, J.; BUTOW, R. A. RTG-dependent Mitochondria-toNucleus Signaling Is Regulated by MKS1 and Is Linked to Formation of Yeast Prion [ URE3 
]. Molecular Biology of the Cell, v. 13, n. March, p. 795-804, 2002.

SEKITO, T.; THORNTON, J.; BUTOW, R. A. Mitochondria-to-nuclear signaling is regulated by the subcellular localization of the transcription factors Rtg1p and Rtg3p. Molecular Biology of the Cell, v. 11, n. 6, p. 2103-2115, 2000.

SHERMAN, F. Getting Started with Yeast • Contents • Methods in Enzymology, v. 350, n. 2002, p. 3-41, 2002.

SINCLAIR, D. A.; GUARENTE, L. Extrachromosomal rDNA Circles - A Cause of Aging in Yeast. Cell Press, v. 91, p. 1033-1042, 1997.

SMITH, E. D.; TSUCHIYA, M.; FOX, L. A.; DANG, N.; HU, D.; KERR, E. O.; JOHNSTON, E. D.; TCHAO, B. N.; PAK, D. N.; WELTON, K. L.; PROMISLOW, D. E. L.; THOMAS, J. H.; KAEBERLEIN, M.; KENNEDY, B. K. Quantitative evidence for conserved longevity pathways between divergent eukaryotic species. Genome Research, v. 18, n. 4, p. 564-570, 17 mar. 2008.

SMITH, R. a; DUNCAN, M. J.; MOIR, D. T. Heterologous protein secretion from yeast. Science, v. 229, n. 4719, p. 1219-1224, 1985.

STEFFEN, K. K.; KENNEDY, B. K.; KAEBERLEIN, M. Measuring replicative life span in the budding yeast. Journal of visualized experiments : JoVE, n. 28, p. 28-30, jan. 2009.

STEINKRAUS, K. A.; KAEBERLEIN, M.; KENNEDY, B. K. Replicative Aging in Yeast: The Means to the End. Annual Review of Cell and Developmental Biology, v. 24, n. 1, p. 29-54, nov. 2008.

TATE, J. J.; COX, K. H.; RAI, R.; COOPER, T. G. Mks1p Is Required for Negative Regulation of Retrograde Gene Expression in Saccharomyces cerevisiae but Does Not Affect Nitrogen Catabolite Repression-sensitive Gene Expression. Journal of Biological Chemistry, v. 277, n. 23, p. 20477-20482, 7 jun. 2002.

TAYLOR, R. C.; DILliN, A. Aging as an Event of Proteostasis Collapse. Cold spring Harbor Perspectives in Biology, v. 1, p. 1-17, 2011.

TEŞILEANU, T.; COLWELL, L. J.; LEIBLER, S. Protein Sectors: Statistical Coupling Analysis versus Conservation. PLOS Computational Biology, v. 11, n. 2, p. e1004091, 2015.

VAN HEUSDEN, G. P. H.; GRIFFITHS, D. J. F.; FORD, J. C.; CHIN-WOENG, a. T. F. C.; SCHRADER, P. a T.; CARR, a. M.; STEENSMA, H. Y. The 14-3-3 proteins encoded by the $\mathrm{BMH} 1$ and BMH2 genes are essential in the yeast Saccharomyces cerevisiae and can be replaced by a plant homologue. European Journal of Biochemistry, v. 229, n. 1, p. 45-53, 1995.

WANG, L.; FRALEY, C. D.; FARIDI, J.; KORNBERG, A.; ROTH, R. a. Inorganic polyphosphate stimulates mammalian TOR, a kinase involved in the proliferation of mammary cancer cells. Proceedings of the National Academy of Sciences of the United 
States of America, v. 100, n. 20, p. 11249-11254, 2003.

WERNER-WASHBURNE, M.; BRAUN, E.; JOHNSTON, G. C.; SINGER, R. A. Saccharomyces cerevisiae. Microbiological, v. 57, n. 2, p. 383-401, 1993.

YU, B. P. Aging and Oxidative Stress: Modulation by Dietary Restriction. Free Radical Biology and Medicine, v. 21, n. 5, p. 651-668, 1996.

ZHANG, F.; PRACHEIL, T.; THORNTON, J.; LIU, Z. Adenosine Triphosphate (ATP) Is a Candidate Signaling Molecule in the Mitochondria-to-Nucleus Retrograde Response Pathway. Genes, v. 4, n. 1, p. 86-100, 20 mar. 2013.

ZHANG, H.; GÓMEZ-GARCÍA, M. R.; BROWN, M. R. W.; KORNBERG, A. Inorganic polyphosphate in Dictyostelium discoideum: influence on development, sporulation, and predation. Proceedings of the National Academy of Sciences of the United States of America, v. 102, n. 8, p. 2731-2735, 2005.

ZHANG, Y. I-TASSER server for protein 3D structure prediction. BMC Bioinformatics, v. 9, n. 1, p. 40, 2008.

ZHONG, Q.; GOHIL, V. M.; MA, L.; GREENBERG, M. L. Absence of Cardiolipin Results in Temperature Sensitivity, Respiratory Defects, and Mitochondrial DNA Instability Independent of pet56. Journal of Biological Chemistry. v. 279, n. 31, p. 32294-32300, 2004. 


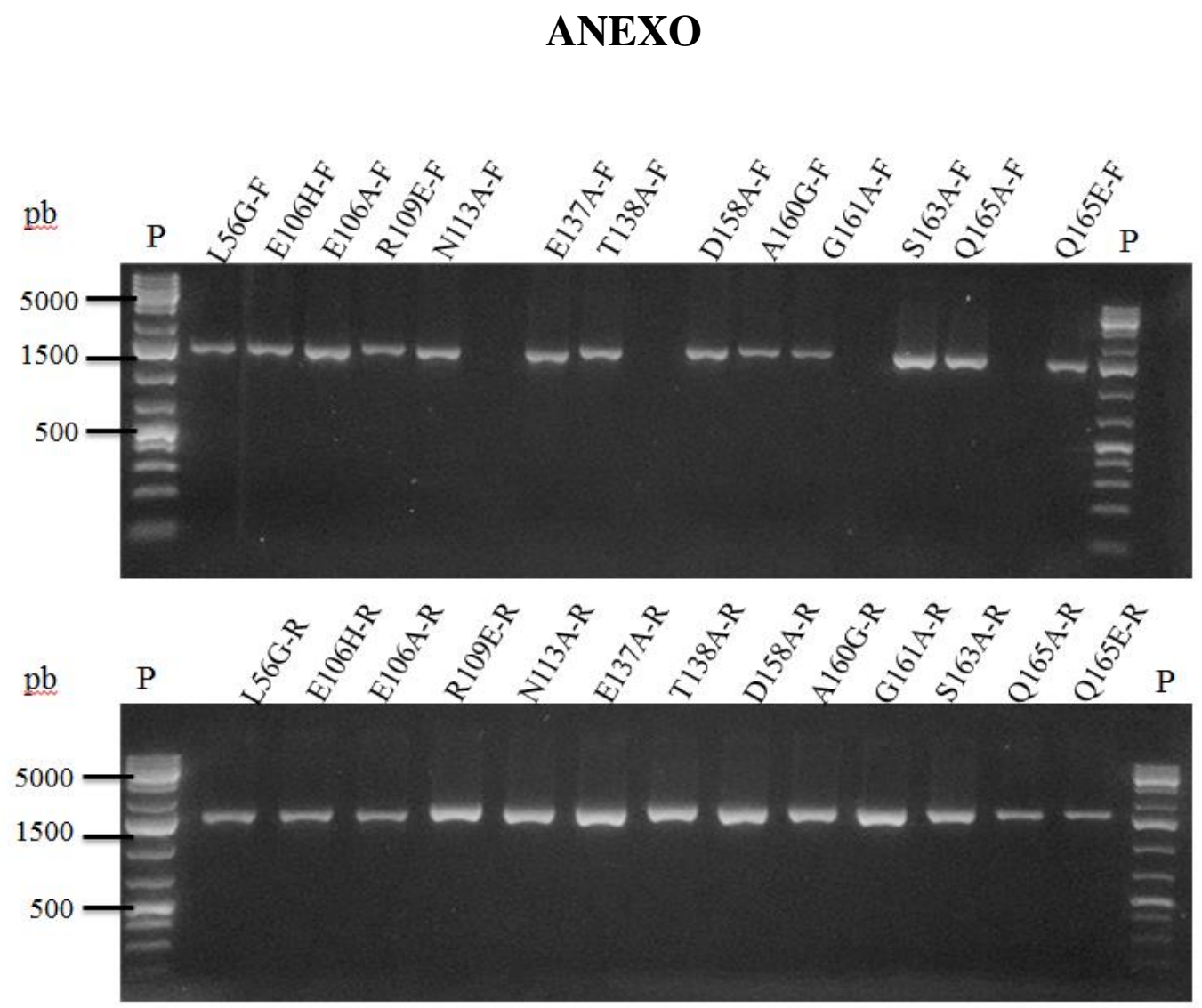

Figura A1 - Eletroforese de cada reação de PCR para gerar os mutantes de RTG2. Os produtos de amplificação dos respectivos mutantes estão indicados F (amplificadas com o primer Forward do mutante - painel superior) e $\mathrm{R}$ (amplificadas com o primer Reverse de cada mutante- painel inferior).

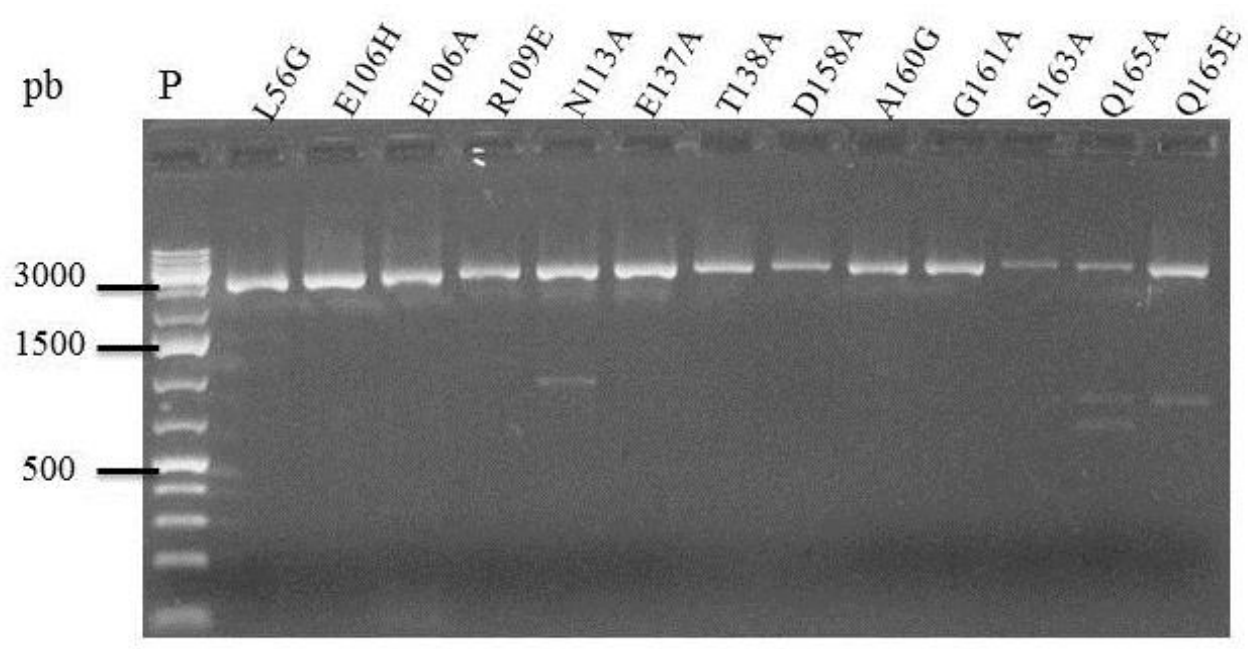

Figura A2 - Eletroforese do produto gerado pela Overlap PCR com cada mutação realizada. As mutações estão indicadas. Todos os produtos de PCR possuem $3067 \mathrm{pb}$. 


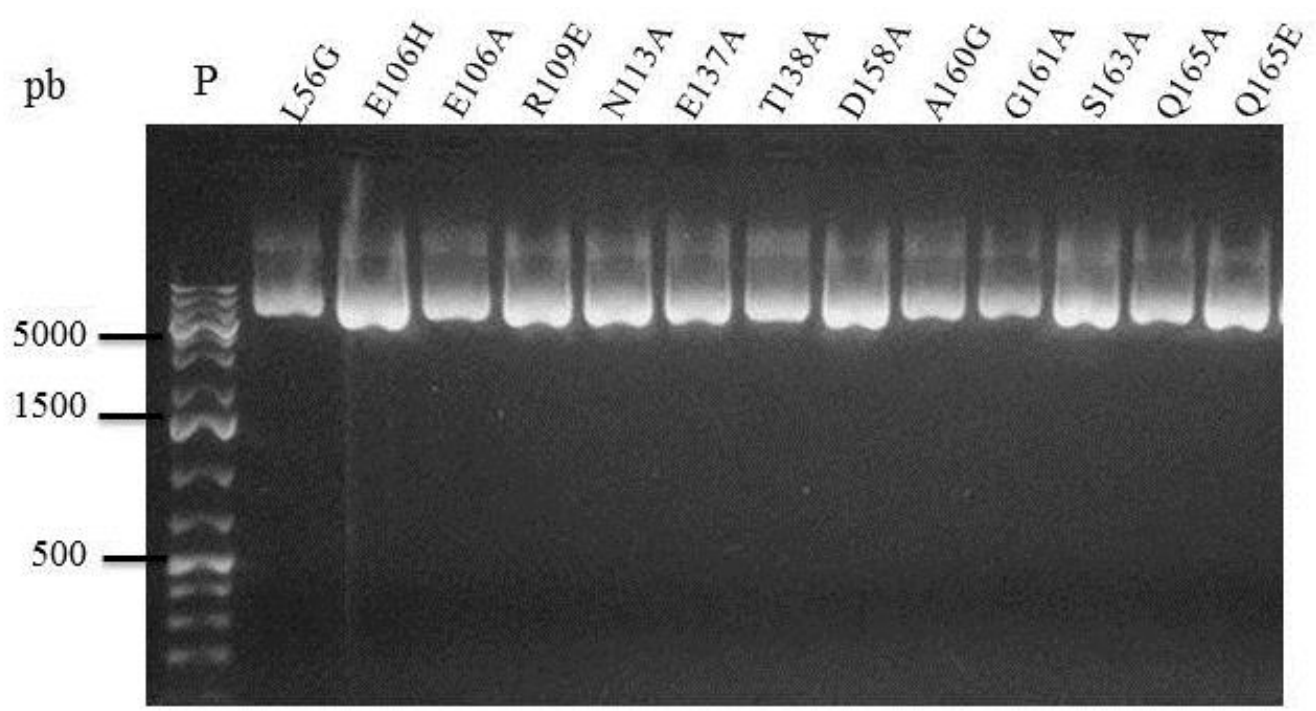

Figura A3 - Miniprep de todos os plasmídeos com as mutações.

Tabela 1A - Análises estatísticas dos experimento de RLS. Valos de $p$ foram avaliados pelo teste nãoparamétrico Mann-Whitney.Comparado com as cepas WT

\begin{tabular}{|c|c|c|}
\hline Mutação & WT & $\operatorname{rtg} 2 \Delta$ \\
\hline WT & ns & $* *$ \\
\hline $\operatorname{rtg} 2 \Delta$ & $* *$ & ns \\
\hline$L 56 G$ & $* *$ & $* *$ \\
\hline$E 106 A$ & $* *$ & ns \\
\hline$E 106 H$ & ns & $* *$ \\
\hline R109E & $* *$ & ns \\
\hline$N 113 A$ & ns & $* *$ \\
\hline E137A & $* *$ & ns \\
\hline$T 138 A$ & $* *$ & ns \\
\hline$D 158 A$ & $* *$ & ns \\
\hline$A 160 G$ & ns & $* *$ \\
\hline G161A & $* *$ & $* *$ \\
\hline S163A & $\mathbf{n s}$ & $* *$ \\
\hline$Q 165 A$ & ns & $* *$ \\
\hline$Q 165 E$ & ns & $* *$ \\
\hline
\end{tabular}

Hipóteses dos testes: Coluna WT: mutante $\neq$ WT, Coluna $r \operatorname{tg} 2 \Delta:$ mutante $\neq \operatorname{rtg} 2 \Delta$. ns: não significativo

$* * \mathrm{p}<0,0001$ 

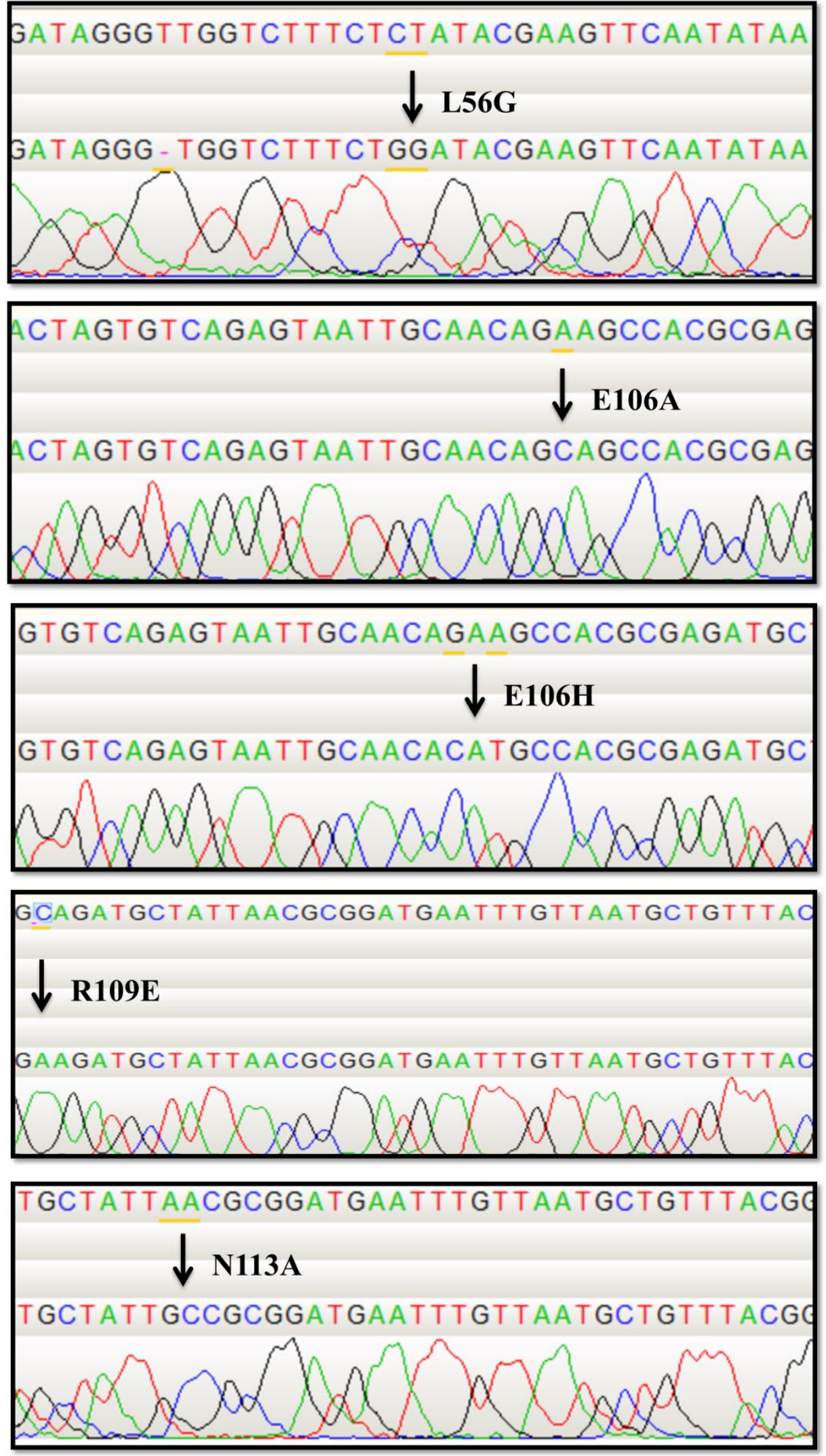

Figura A4 - Sequenciamento indicando mutações pontuais realizadas indicadas por setas s em preto. 


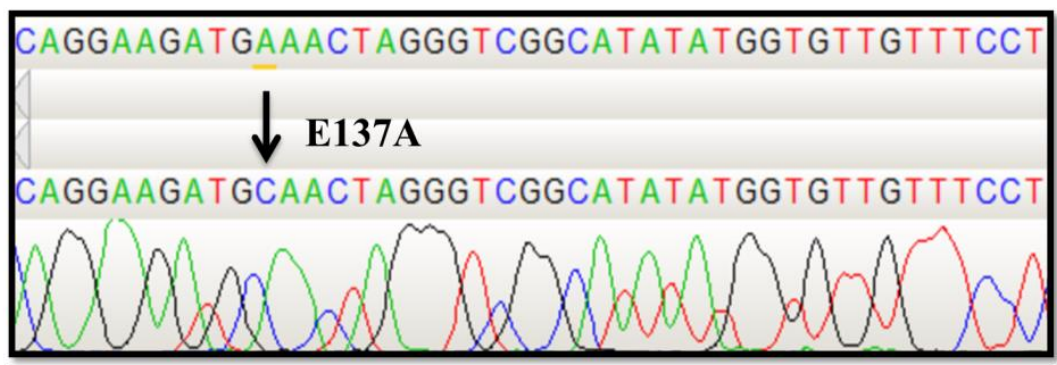

GAAACTAGGGTCGGCATATATGGTGTTGTTTCCTCATT

T138A

GAAGCTAGGGTCGGCATATATGGTGTTGTTTCCTCATT
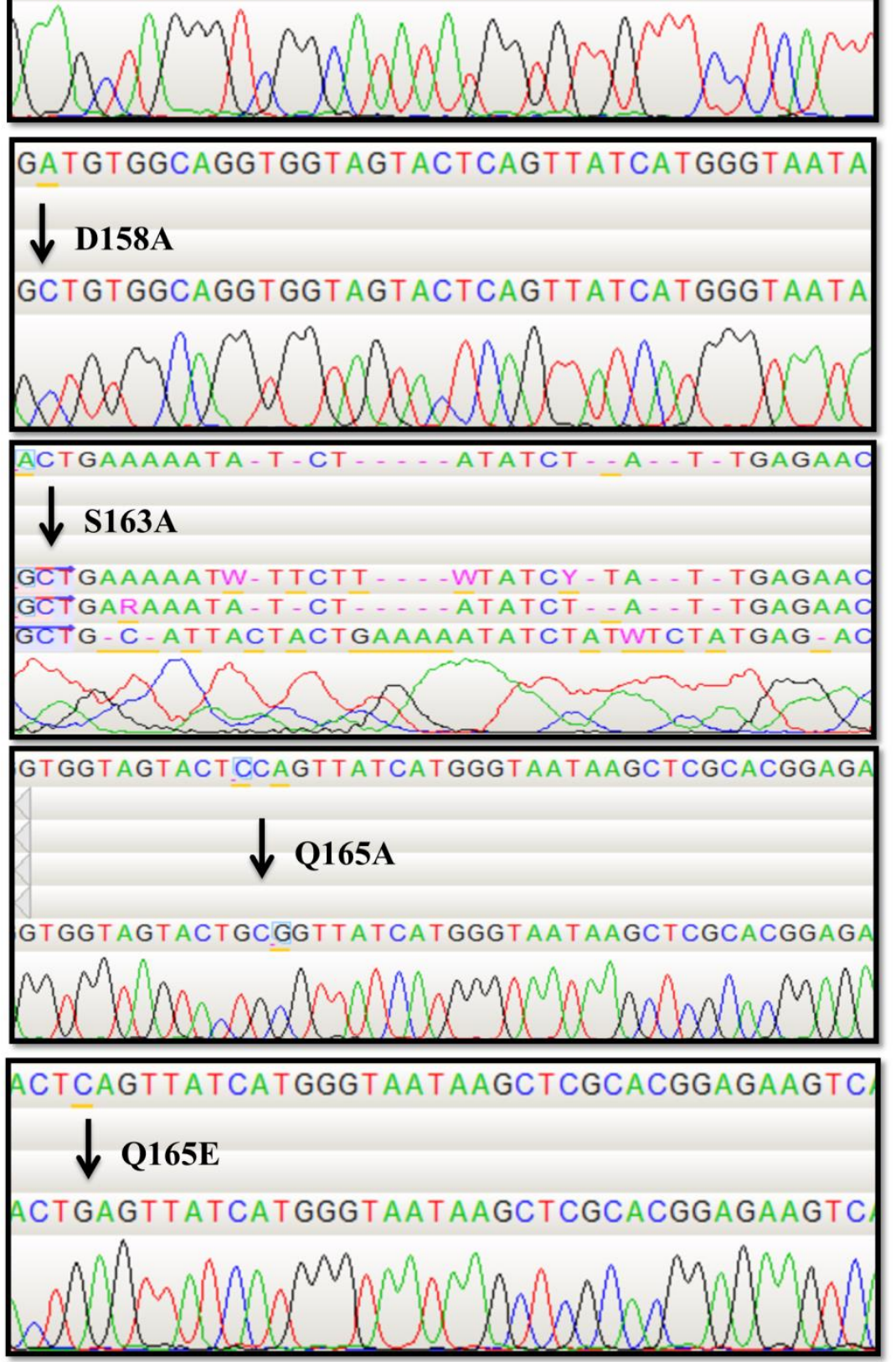

Figura A5 - Sequenciamento indicando mutações pontuais realizadas indicadas por setas s em preto. 